\title{
Development Strategy of Endodontic Filling Materials Based on Engineering and Medical Approaches
}

\author{
Leszek A. Dobrzański ${ }^{1,2, *}$, Joanna Dobrzańska ${ }^{1,3}$, , Lech B. Dobrzański ${ }^{1,3}$ (i), \\ Anna D. Dobrzańska-Danikiewicz ${ }^{4}(\mathbb{D})$ and Klaudiusz Gołombek ${ }^{5}$ (i) \\ 1 Medical and Dental Engineering Centre for Research, Design and Production ASKLEPIOS, 12/1 King Jana III \\ Sobieskiego St., 44-100 Gliwice, Poland; joanna.dobrzanska@centrumasklepios.pl (J.D.); \\ dobrzanski@centrumasklepios.pl (L.B.D.) \\ 2 Department of Biomedical Engineering, Koszalin University of Technology, 2 Sniadeckich St., \\ 75-453 Koszalin, Poland \\ 3 Medical and Dental Centre SOBIESKI, 12/1 King Jana III Sobieskiego St., 44-100 Gliwice, Poland \\ 4 Faculty of Mechanical Engineering, University of Zielona Góra, 4 Prof. Z. Szafrana St., \\ 65-516 Zielona Góra, Poland; anna.dobrzanska.danikiewicz@gmail.com \\ 5 Faculty of Mechanical Engineering, Silesian University of Technology, 18 A Konarskiego St., \\ 44-100 Gliwice, Poland; klaudiusz.golombek@polsl.pl \\ * Correspondence: leszek.dobrzanski@centrumasklepios.pl
}

Citation: Dobrzański, L.A.;

Dobrzańska, J.; Dobrzański, L.B.;

Dobrzańska-Danikiewicz, A.D.;

Gołombek, K. Development Strategy of Endodontic Filling Materials Based on Engineering and Medical Approaches. Processes 2021, 9, 2014. https://doi.org/10.3390/pr9112014

Academic Editor: Anil K. Bhowmick

Received: 7 October 2021

Accepted: 5 November 2021

Published: 11 November 2021

Publisher's Note: MDPI stays neutral with regard to jurisdictional claims in published maps and institutional affiliations.

Copyright: (c) 2021 by the authors. Licensee MDPI, Basel, Switzerland. This article is an open access article distributed under the terms and conditions of the Creative Commons Attribution (CC BY) license (https:/ / creativecommons.org/licenses/by/ $4.0 /)$.

\begin{abstract}
This article is a literature review aimed at presenting the general state of knowledge in manufacturing engineering and materials engineering to develop engineering materials applied for endodontic treatment as filling materials. Particular attention was paid to theoretical analyses concerning the selection of methods for developing and obturating root canals and discussing the results of experimental studies available in the literature. These activities aimed to compare the importance of the most commonly used endodontic filling materials based on gutta-percha or polymeric polyester materials, commonly known as resilon, respectively. The motivation to take up this complex, multi-faceted topic in this paper is the extent of caries, periodontal disease, and other oral diseases in 3 to 5 billion people, often affecting toothlessness and contributing to an increase in the index of disability-adjusted life years (number). Endodontics is an important element of the authors' concept of Dentistry Sustainable Development (DSD) > 2020. The principles of qualifying patients for endodontic treatment are discussed. The introduction of rotary tools, especially manufactured from Nitinol alloy, to develop root canals and the latest thermohydraulic and condensation techniques for obturation guarantee progress in endodontics. The "Digital Twins" methodology was used, rooted in the idea of Industry 4.0 and the resulting idea of Dentistry 4.0, as well as knowledge management methods, to perform experimental research in virtual space, concerning methods of developing and obturating the root canal and assessing the tightness of fillings. Microscopic visualization methods were also used. Significant factors determining the effectiveness of endodontic obturation are the selection of the filling material and the appropriate obturation method. The generalized dendrological matrix of endodontic filling materials considers the criteria of mechanical strength influencing the potential root fracture and the quality of root canal filling. The results of the SWOT point analysis (strengths and weaknesses, opportunities, threats) were also compared. For both filling materials, the weaknesses are much less than the strengths, while the threats are slightly less than the opportunities for the gutta-percha-based material, while for resilon the opportunities are much smaller than the threats. It requires the application of an appropriate development strategy, i.e., MAXI-MAXI in the case of a filling material based on gutta-percha and MAXI-MINI in the case of resilon. Therefore, the analysis of these experimental data does not indicate the real competitiveness of resilon for the gutta-percha-based material. This material deservedly maintains its strong position as the "Gold Standard of Endodontics".
\end{abstract}

Keywords: materials science and engineering; dental engineering; dentistry; endodontics; filling materials; gutta-percha; resilon; sealants; obturation; cold side condensation; thermoplastic obturation; thermo-hydraulic condensation technique; scanning electron microscope; laser stereoscopic microscope 


\section{General Characteristics of the Problem}

The challenges of modern civilization take many aspects, and it turns out that they can and should be met in various, even surprising, modes. Most generally, they are about sustainable development, consisting of satisfying the justified needs of all people with respect for the rights and expectations of everyone, in ensuring general prosperity with possibly equal access to all goods by all people and with the wide development of partnership between them, to ensure peace as one of the highest values and with full care for the development of the planet and the preservation of its natural resources for future generations. These general assumptions and expectations, defined as the five Ps of sustainable development [1] (Figure 1), were at the basis of the UN designating seventeen Sustainable Development Goals (SDGs) [2].

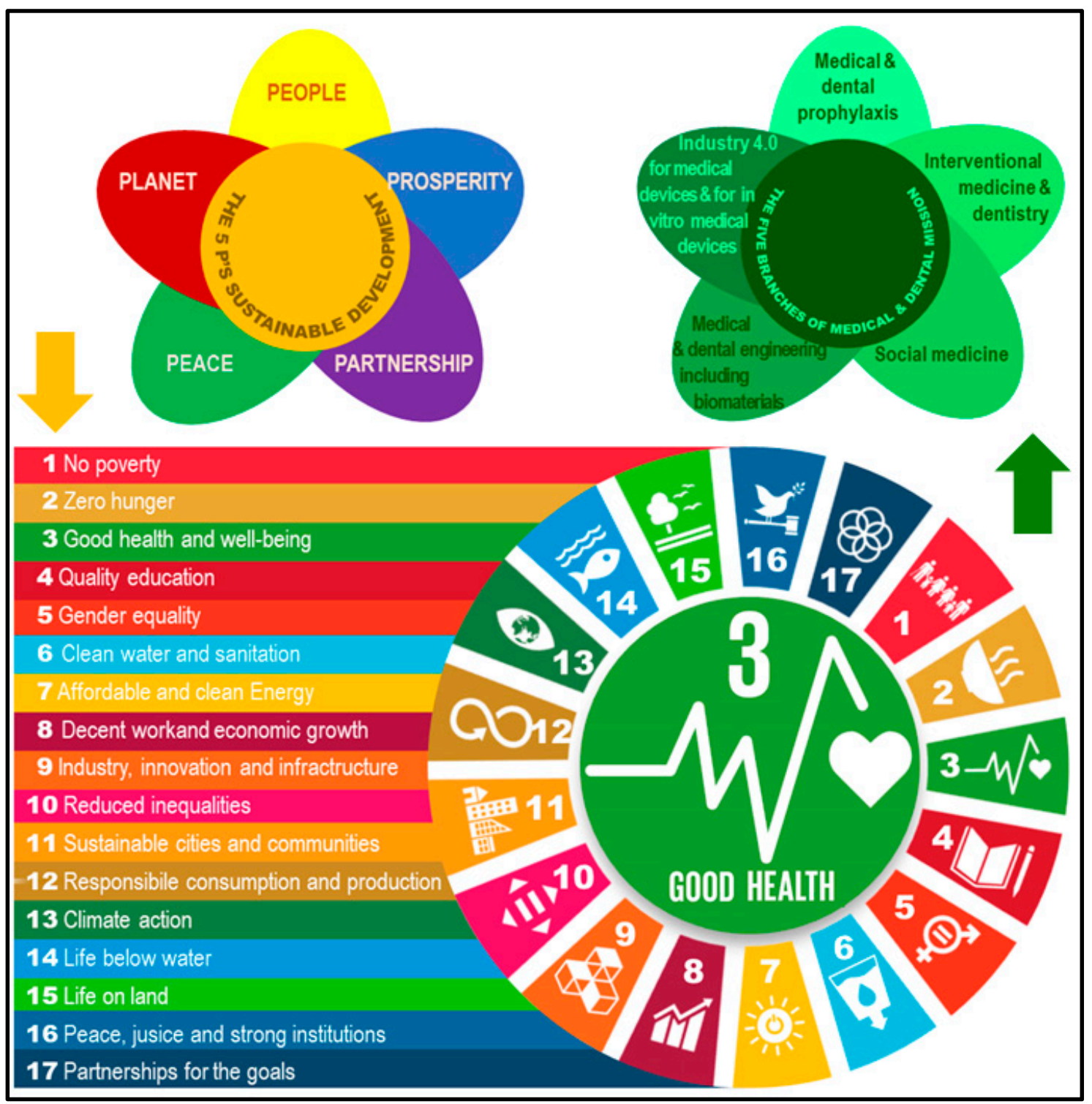

Figure 1. Diagram of five general assumptions of sustainable humanity development at the present stage with the resulting seventeen Sustainable Development Goals established by the United Nations and the resulting five branches of the medical and dental mission.

Among these SDGs, the third designated SDG on health and all related aspects occupies a prominent place. This goal requires action in various areas and requires an appropriate organization and modernization of health systems specified in the EU4 Health 
Program [3]. This program aims to protect against serious health threats, especially such as diseases of affluence, pandemics, and bioterrorism. The methods listed include improving the health of society, medical care, and health safety, manifested in the prevention of health risks, the early diagnosis of diseases, the efficient and effective implementation of medical procedures, the improvement of the effectiveness of health systems, and the modernization of health care infrastructure and comprehensive and developmental medical therapies. Such actions, for example, are set out in detail in the European Health Strategy [4]. They are targeted at individual citizens by recognizing their right to their own health and health care and protection against threats to their health and life. It is enough to associate the famous saying of Georges Benjamin Clemenceau (1841-1929), the Prime Minister of France in 1906-1909 and again in 1917-1920, that "War is too serious thing to be entrusted to the soldiers." This saying has been repeatedly paraphrased in history, among others, by General Charles de Gaulle (1890-1970), President of France in 1959-1969, who said that "Politics is too serious thing to be entrusted to the politicians." Undoubtedly, the matters of health protection, extending human life, and improving the well-being of people in the world do not remain and cannot be the sole responsibility of doctors and representatives of other medical professions. The currently achieved level in this regard is the achievement of many different professional groups, although it is invariably doctors who have contact with the patient and are directly responsible for the results of treatment and prophylaxis. Biologists, biophysicists, biochemists, psychologists, and various other professions, as well as engineers of various specialties, have a huge share in this matter. Figure 1 shows the scope of general activities to ensure good health and well-being on a global scale. The multifaceted nature of the problem makes it impossible to limit the considerations on any topic covered by the same 3rd SDG UN to a medical approach only. It is non-effective to address the concerns in this matter only to medics of the appropriate specialty, e.g., dentists, when aspects of the diagnosis and treatment of oral diseases are considered, including implant prosthetic and endodontic treatment. It is not the dentist who designs and manufactures both implants and prosthetic restorations, as well as filling materials used in conservative dentistry and endodontics. It is obvious that this article on the design of engineering materials for applications in dentistry is dedicated to dental engineers and their collaborating material engineers and manufacturing engineers, but also to dentists, as well as to medics of other specialties, due to systemic complications that have their genesis in diseases of the oral cavity. The dentist acquires the appropriate material or device based on the characteristics of the medical device, and it is not for them to wonder how and why it was designed and manufactured. They want to know its functional characteristics, but it is also not their job to develop development strategies for a given product, which is what this article is about because it is the task and goal of the producers of this material. It seems that these obvious truths are not known to many readers of such cognitively complex studies, so the introduction to the paper must contain a very wide range of concepts. For an engineer, it may seem unnecessary to remind you of the obvious issues in the basics of designing and manufacturing engineering materials, which dentists certainly do not know and may find difficult to study these issues. Vice versa, the basics of dental treatment, which are essentially close to dentists, are new and therefore necessary for engineers, although their perception of this professional group may not be easy. However, there is no doubt that an engineer, to design or even redesign or simply modernize any engineering material, must know in detail the conditions of use and operating and maintenance conditions of a given material. Therefore, the point is that these various professional groups should get to know each other's issues because only the synergy of knowledge and actions can bring beneficial effects to patients, and it is their welfare that is at stake here. This is the overarching message. Therefore, it is not true as if it would seem to someone that on the one hand general and the other hand detailed content, as indicated above, are superfluous and should be omitted in part or in full, or even worse, included in various parts, e.g., different papers, because then a large group of potentially interested readers may never find these remaining parts. Only a holistic and monographic approach to the problem can achieve 
the previously mentioned, assumed goals of such a message. If it were otherwise, it would mean that the purpose of this synergistic cooperation of people of different professions would be destroyed to ensure, within the scope specified in this article, the possibility of implementing the 3rd SDG on a global scale.

An illustration of this problem is a tree photographed by the authors of this article in the forests of the Roztocze National Park in southeastern Poland, not far from the very famous historical town of Zamość, typical of the European Renaissance, included in the UNESCO cultural heritage list (Figure 2a).

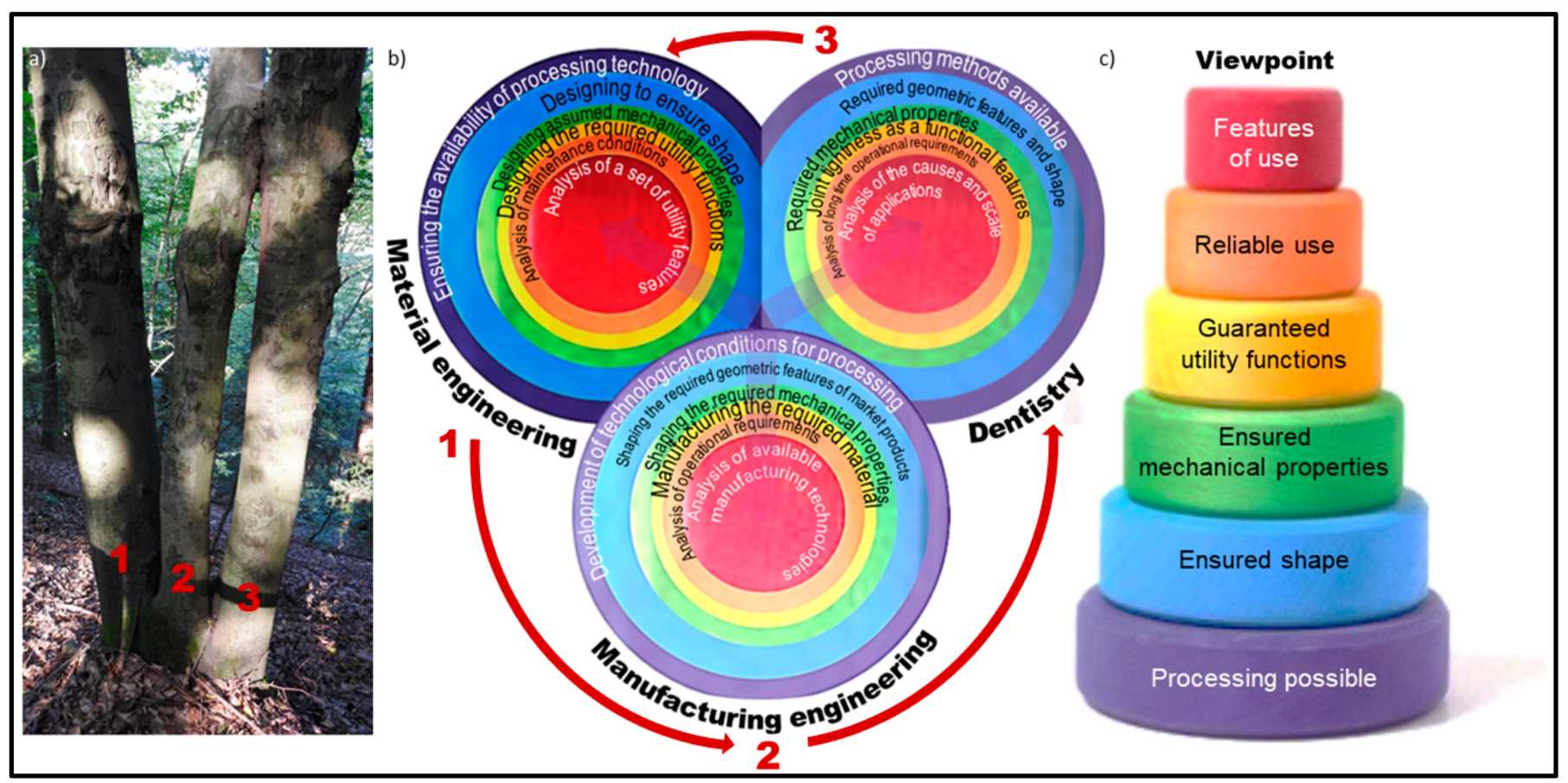

Figure 2. An example of beech with a triangularly branched trunk in Roztocze National Park in Poland (a) with synergy diagrams of materials engineering, manufacturing engineering, and dentistry (b) and a hierarchical arrangement of the main analyzed issues concerning filling materials used in endodontics (c).

The following basic issues coming from a common virtual trunk are analyzed, i.e., features of use, reliable use, guaranteed utility functions, ensured mechanical properties, ensured shape, and possible processing. The diagram in Figure $2 \mathrm{~b}$ shows a symbolic cross-section of a virtual trunk split into three parts, considering the analyzed aspects from three fundamentally different points of view, i.e., materials science, manufacturing engineering, and dentistry. They come from a common trunk, illustrated by centrifugal arrows oriented towards each other under an angle of $120^{\circ}$. The solution to this problem is materials engineering, so not including mainly dentistry including endodontics as one of its parts. Therefore, it is necessary to analyze the aspects mentioned above in the realities of each of the above-mentioned scientific disciplines. These aspects cannot be omitted or simplified to such an extent that it is not understandable for readers representing two other than their own professional experience and knowledge range. A positive result of dental treatment, and in this case endodontic treatment, should be understood as a specific virtual imaginary result vector resulting from the vectorial summation of all component vectors corresponding to the mentioned issues for which corresponding colors were selected appropriately for each of the three points of view. Only the interaction and synergy of these factors can produce a positive result, and this symbolic virtual result vector will acquire both the appropriate value and the direction and turn.

Therefore, the aim of this paper is a comprehensive presentation of the design conditions of engineering endodontic filling materials, which are one of the typical dedicated 
engineering materials, and multi-faceted analysis of the conditions of their use and the quality and durability of the performed endodontic fillings (Figure 3).

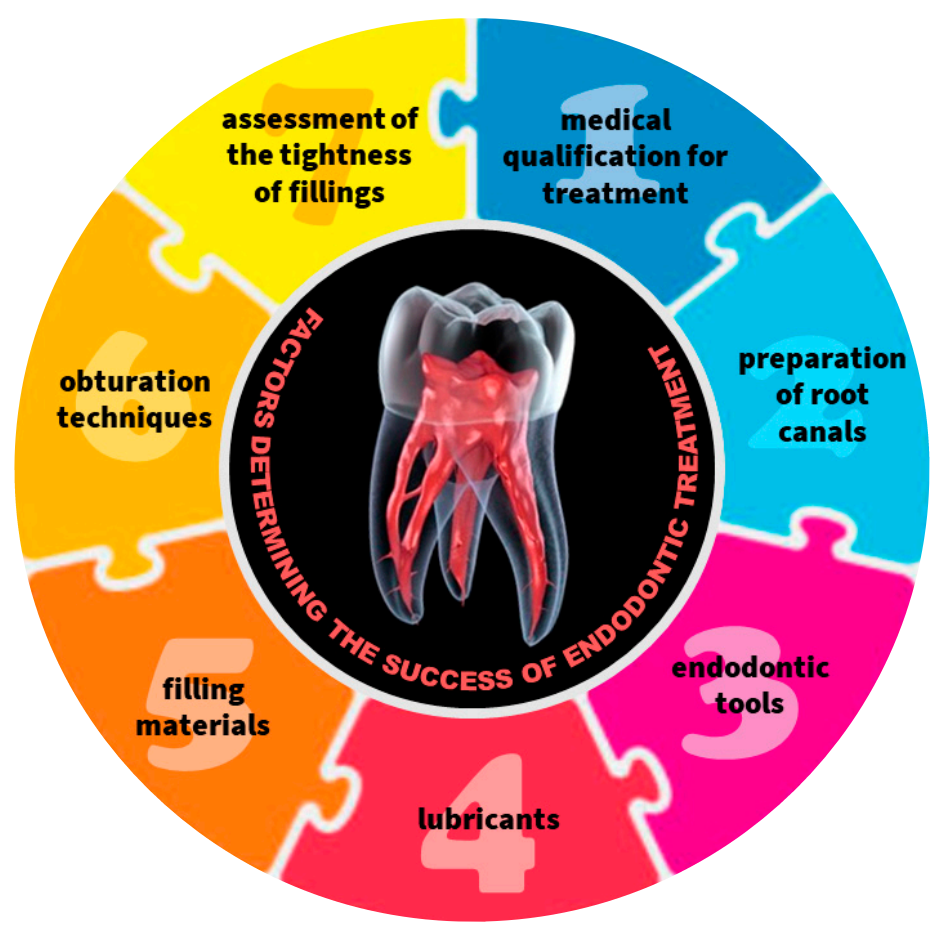

Figure 3. Scheme of the factors determining the success of endodontic treatment.

For this analysis, a wide set of methods was used, not only in materials science and manufacturing engineering, but also in management engineering and knowledge management, and technological foresight. It is an original approach, however, requiring a consistent analysis of the impact of all component factors, not just selected ones. The aim of this paper is also to present the general state of knowledge on endodontic treatment, with particular emphasis on theoretical analyses regarding the selection of root canal development and obturation methods, as well as to discuss the results of experimental studies available in the literature in order to compare the validity of the selection of the most commonly used filling materials in endodontics. They are suitably based on gutta-percha or polymeric polyester materials, commonly known as resilon. The results of experimental studies with the use of stereoscopic and scanning electron microscopes as well as the results of the SWOT analysis (Strengths-Weaknesses-Opportunities-Threats) and the analysis of the dendrological matrices are presented.

\section{Scope of the Development of Manufacturing Technologies and Engineering Materials, Taking into Account the Specifics of Dental Engineering}

It should be realized that the methodological aspects of product development, from scientific research to engineering design and also manufacturing, are not really different, whether they are spacecraft, airplanes, cars, machine tools, dental implants, or dental restorations [5-8]. For obvious reasons, the working conditions or the use of each of these products and the engineering materials used vary in various industries and areas of life. Due to the achieved level of the technological revolution of Industry 4.0, it is necessary to respect this concept in all areas of modern production $[9,10]$. The assumed development is to be intelligent, inclusive, and sustainable, despite the current difficult global economic situation and the accompanying problems, such as climate change, increased consumption, the depletion of traditional energy sources, threats to food safety, and the progressive aging of society, which needs a higher level and intensity of health care. 
The essence of economic activity is the production of all products that can meet the market acceptance of buyers. Manufacturing is the transformation of raw materials into products through a variety of processes, machinery, and operations organized according to a well-developed plan. Therefore, the production process is about the proper use of resources: materials, energy, capital, and people. Nowadays, manufacturing is a complex activity that connects people who perform various professions and activities, using various machines, equipment, and tools, to a varying degree automated, including computers and robots, and is used to introduce to the market new products, which are often completely innovative.

In the process of introducing products to the market, three main spheres can be indicated:

- Marketing and sales;

- Product development;

- Production.

In each of these spheres, appropriate decisions should be made depending on the implementation stage of tasks related to the preparation of products for launch on the market.

Figure 4 shows a general model of manufacturing engineering in the form of an octahedron, resulting from market activities, combining both marketing activities and market insight, as well as target distribution, promotion, and sale of manufactured products and their servicing, as well as market research to improve the current product [5-8].

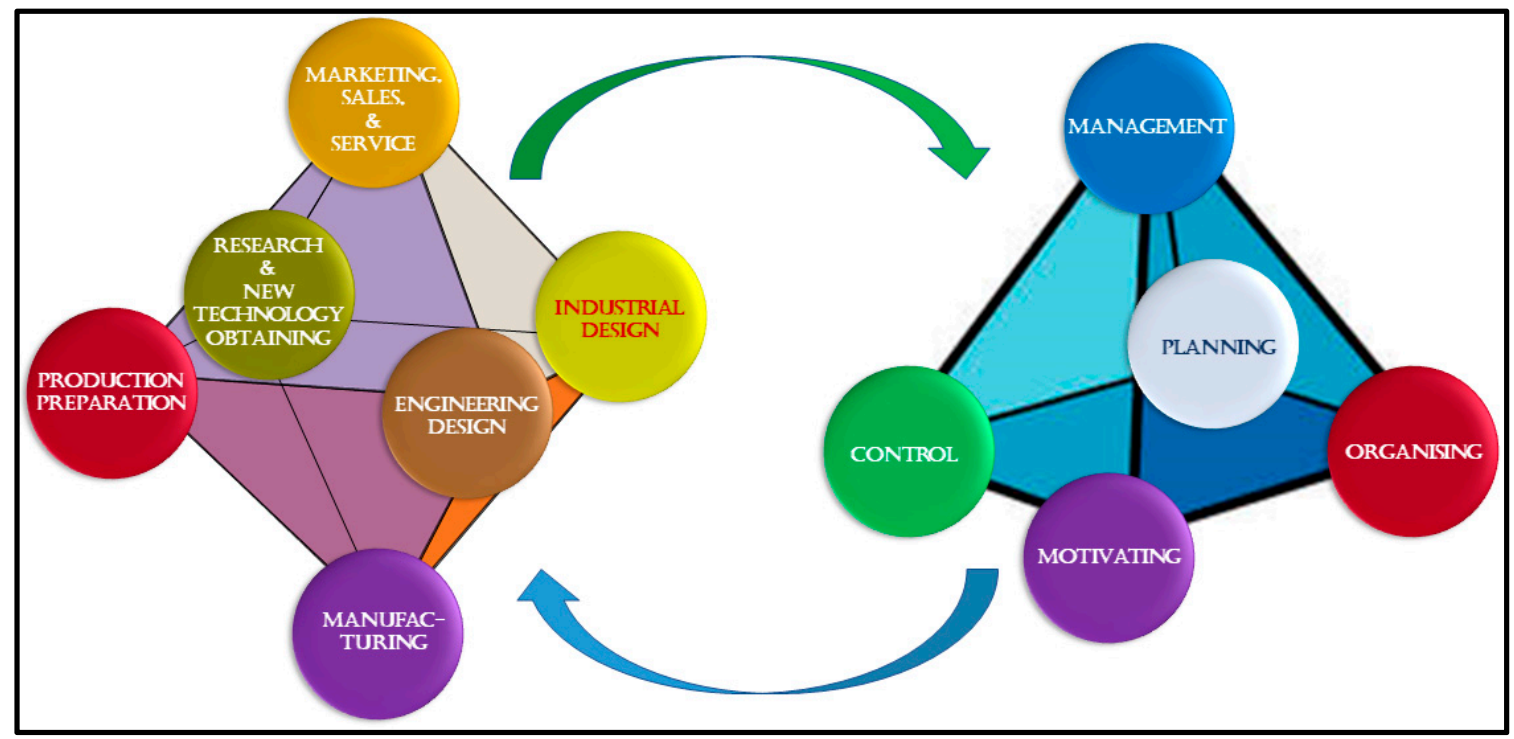

Figure 4. General model of manufacturing engineering with a reactive general management model related to it, e.g., in this sphere.

The actual manufacturing of any product requires research as well as the development and implementation of a new technology, necessarily according to the best possible strategy, corresponding to the stage of market development of the product, as well as its advantages over emerging competitive solutions. Starting production according to such a developed technology requires industrial design, engineering design, as well as production planning, generally referred to as product development. Only in this way can structured production be effectively the basis of manufacturing. At the same time, the right part of the scheme consists of managerial activities accompanying every human activity, and therefore also manufacturing, including planning, organizing, motivating, and controlling.

The strategy of a company or organization dealing with production or concerning simply the production of a specific market product is developed each time, using the available possibilities, materials, technologies, and devices, as the basis for satisfying the market needs of customers through production. The technical aspects of the process of introducing a given product to the market by a manufacturing organization relate to industrial design, engineering design, production preparation, manufacturing, and service 
support, as outlined in the octahedron of manufacturing engineering (Figure 3). The first phase of product design concerns industrial design related to the general description of the product's functions and the development of its general concept, including only the external form, color, and possibly general assumptions as to the connection of the main elements. The next phases include engineering design and subsequent production preparation. Engineering design, in which the design of the production system and product design can be distinguished, is not an isolated activity because it affects all other phases of introducing a given product to the market, on which it is also dependent. Product design combines three equally important and inseparable elements (Figure 5). Regardless of the application sphere, and therefore also for medical and dental applications, and also regardless of whether it is a product applied to the human body, or whether it is any medical device or device used in medicine or dentistry, all activities undertaken in the application of engineering materials are based on the materials science paradigm, expressed by the $6 \times \mathrm{E}$ six-expectation rule in the form of an octahedron (Figure 5).

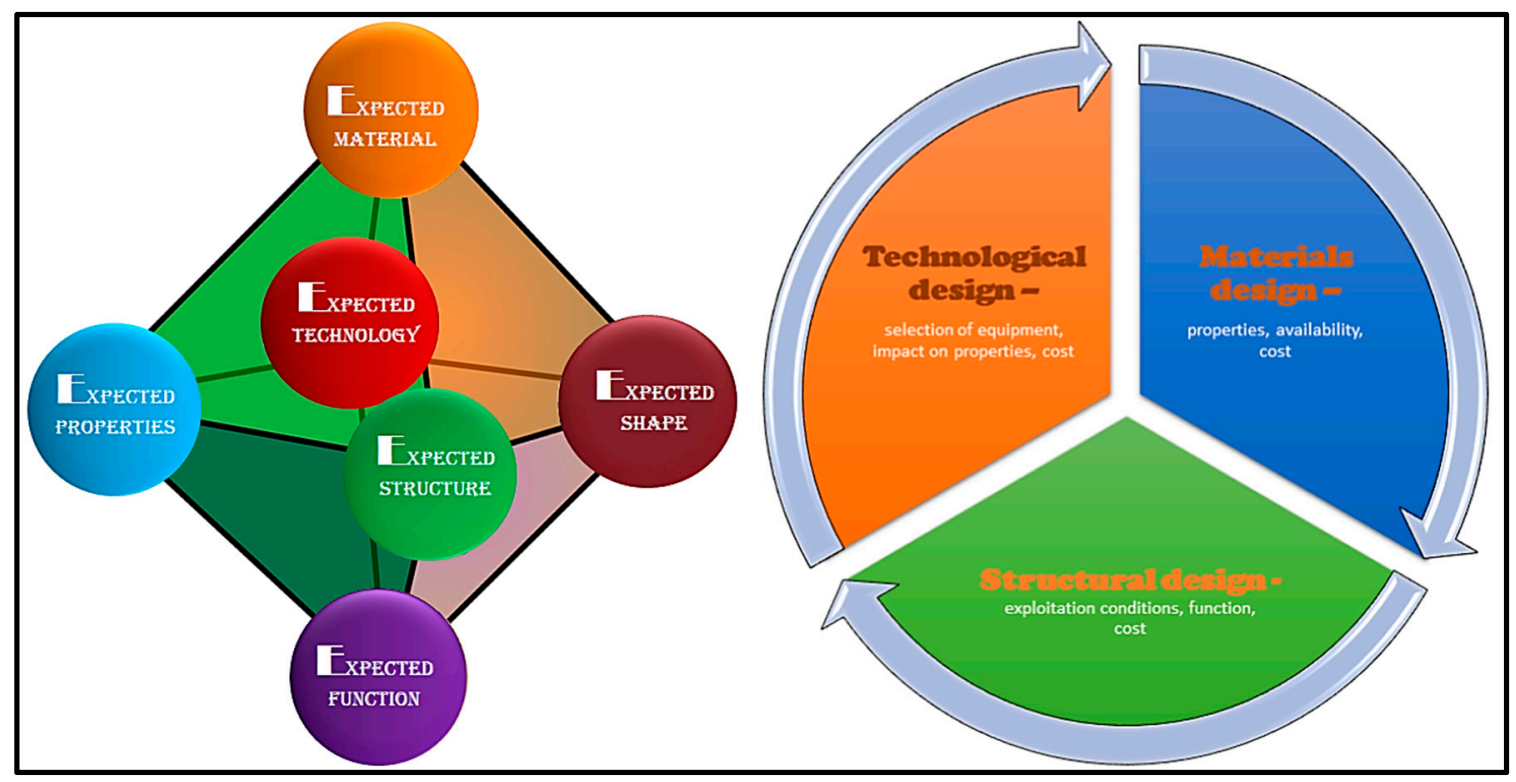

Figure 5. Fundamentals of engineering design: $6 \times$ E rule's octahedron; synergy of material, technological and structural design.

The utility functions of the products expected by the customer will be ensured if the expected engineering material is used for their production and processed with the use of technology of the expected quality, in order to obtain the expected shape of the final product with the expected structure and expected mechanical and functional properties that provide these functional features of a product [5-8]. From the point of view of engineering practice, the most important task is, therefore, to design and manufacture products with all expected utility values and functional properties required for technical reasons. Modern engineering design is a complex, comprehensive process that includes closely related and mutually complementary areas of activity: material design, structural design of product forms, and technological design of product manufacturing, in a wide range including, among others, material process technologies (Figure 5).

Currently, over 100,000 different engineering materials are known and used in the world. The results of research carried out as part of the technology foresight of Europe announced in the reports on the implementation of the projects The Future of Manufacturing in Europe (FutMan) and Manufacturing Visions the Futures Project (ManVis) indicate the expectation of producing materials with properties ordered by product users. It has been the case almost from the beginning of this millennium. Materials should be provided with an appropriately shaped structure that guarantees the required set of physicochemical properties. The production of materials on demand (MOD), meeting the needs of market 
producers at the right time and place, is a priority of modern material technologies and manufacturing processes. The expectation of producing materials with properties ordered by users of products fundamentally changes the methodology of material design in general and the material design of specific products. Forecasts, including European countries, enforce the classification of engineering materials due to their functional characteristics. Therefore, the type of material used is less important, and its functionality is more important. There has been a change in the assessment of the role of engineering materials, which cannot still be seen as goods in themselves, with the applications sought for them, and the market for new engineering materials is no longer the manufacturer's market. It is because new engineering materials and manufacturing processes are subordinated to the customer's needs and the functional functions of the products. Such a modified material design methodology is related to numerous activities specified in ManVis European Foresight, related to the modeling and simulation of manufacturing processes and the prediction of operational properties of materials, the development of safe material technologies and products composed of nano-structured elements, the standardization of material properties tests, especially nano-structured ones, and the development of prediction methodology behavior of new materials during operation. The scope of materials science and materials engineering as well as engineering design of products includes the correct selection of material for a given application based on multi-criteria optimization related to belonging to one of the four basic groups of materials (metals, polymers, ceramics, composites), chemical composition, conditions manufacturing, operating conditions, and the method of removing material waste in the post-use phase, as well as price conditions related to the acquisition of material, its processing into a product, the product itself, as well as the costs of post-production and post-exploitation waste disposal, as well as modeling all processes and properties related to materials [5-8].

It is this general and universal approach to solving any problem related to the engineering design of each product that requires a detailed analysis of the causes and conditions related to the use of a given material in each detailed analyzed case. It is, therefore, the basis of a wide literature review on diseases of the oral cavity, dentistry, and its special field, which is endodontics. It is because such an analysis allows dental engineers, and more generally materials engineers, to optimize material design. Such a literature review on general operating conditions for this class of products is provided in the next section of this paper.

\section{Scope of Oral Cavity Diseases and the Endodontics within the Concept of Sustainable Dentistry Development}

Caries, one of the most common infectious diseases affecting humanity [2,11-26] on an epidemiological scale, similarly to periodontal diseases [27-35] and other diseases of the oral cavity, affects 3 to 5 billion people worldwide [3,28-38]. Caries is caused by the dynamic imbalance between demineralization and remineralization [3,24-29,39,40] depending on the interaction between the tooth structure, saliva, genes, sugars, and starch derived from the diet and bacterial biofilm on the tooth surface, and depends on psychological, social, and behavioral factors [17,20,36,41]. With a low flow of saliva and a high level of sugars in the diet, influencing unfavorable conditions in the oral cavity, a set of endogenous microorganisms, referred to as biofilm as a conditioning layer for primary bacterial colonizers, promotes the demineralization process and the development of caries [42-44]. However, biofilm may play a different role $[43,45]$ because bacteria can produce alkalis, especially in the presence of nitrogen [46], and some bacteria even use lactic acid as an energy source [47]. In these cases, the blocking of caries may even occur. Therefore, the development of caries depends on the synergy of sugars in the diet and the presence of a tooth biofilm [20,48-50], which occurs when the pH of the tooth biofilm is lowered. Thus, the modification of the composition and metabolic activity of the tooth biofilm is indirectly dependent on nutritional factors. A protein-fat diet ensures the neutral $\mathrm{pH}$ of the biofilm and blocks the development of caries [51]. In contrast, a carbohydrate diet, mainly sugar, reduces the $\mathrm{pH}$, favoring the development of caries [48,52]. A share 
of sugars in the diet above 5\% of the daily energy consumption is the limit [39], which is, however, slightly higher in the presence of fluorine [53-55], and partly also of calcium and phosphate [56].

The balance of mineralization and demineralization processes in the oral cavity is appropriate for a healthy state [57-59]. The lack of this balance results in the resultant demineralization of the tooth surface, consisting in a dissolution of hydroxyapatite $\left(\mathrm{Ca}_{10}\left(\mathrm{PO}_{4}\right)_{6}(\mathrm{OH})_{2}\right)$ and diffusion of its components outside [24], which promotes the development of caries. The reason for this is a decrease in $\mathrm{pH}$ due to the presence of organic acids, mainly lactic acid, as a result of sugar metabolism [42]. The rate of demineralization increases as $\mathrm{pH}$ [60] decreases below $\mathrm{pH}=5.5$ for enamel and $\mathrm{pH}=6$ for dentin. The differentiation of the $\mathrm{pH}$ value in different places causes an independent local and dynamic course of demineralization and remineralization in different places. There is a so-called white spot without cavitation on the enamel surface because demineralization is slower on the surface than in the subsurface enamel. When demineralization processes dominate, cavitation occurs on the surface $[36,61]$. Remineralization processes involving the re-deposition of calcium [62,63], sodium [64], and phosphate ions [65] are intensified in the presence of fluorine [65-69]. Fluorapatite provides a much lower susceptibility to the development of caries [36], as it undergoes demineralization in the enamel when the $\mathrm{pH}$ is lowered below $\mathrm{pH}=4.5$, which means that it is much more resistant to enamel demineralization than hydroxyapatite.

The result of caries and other periodontal diseases is removing single teeth and often complete toothlessness. Although tooth extraction, which is often not avoidable, allows for immediate problem resolution, it inevitably leads to the cessation of efficient functioning and the imbalance of the stomatognathic system. Dental cavities, which determine the number of closure pairs and affect the position of the remaining teeth, have a significant impact on the oral health-related quality of life (OHRQoL) [70]. Both oral diseases and partial, and especially complete, toothlessness cause an obvious loss of aesthetic value. More importantly, they cause the risk of numerous serious systemic complications and sometimes even cause a direct loss of life [71-76]. The development of oral diseases, in particular caries, and the resulting toothlessness has a significant impact on the disabilityadjusted life years (DALY) indicator (Figure 6) [36].

The basis of the considerations contained in this article is the fundamental doctrinal dispute in the pages of the scientific press. The Lancet $[37,38]$ presents a series of two provocative articles in which the authors contest the current development of dentistry, pointing to the basic errors which, in their opinion, require a radical change of approach. In their view, it is necessary to move away from interventionist treatment in favor of very broad and ubiquitous prophylaxis, requiring the egalitarian reach of almost every inhabitant of the planet with dental care. Even though all possible efforts must be made to develop prevention, such an approach is simply impossible and extremely utopian. For this reason, in Processes [36], the authors presented their own real and competitive concept of the Dentistry Sustainable Development (DSD) > 2020 model, consisting of Global Dental Prevention (GDP), Advanced Interventionist Dentistry 4.0 (AID 4.0), and the Dentistry Safety System (DSS). 


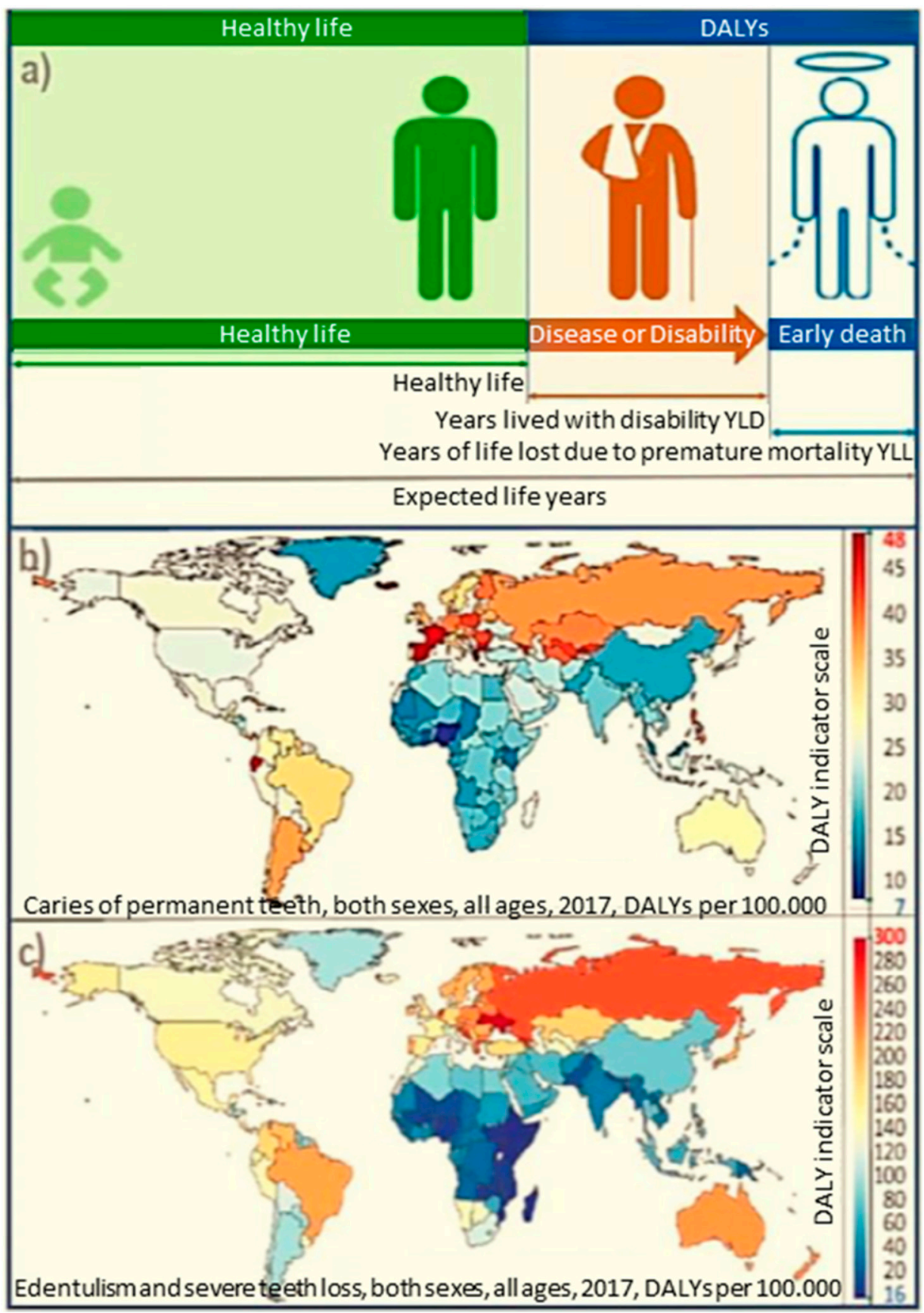

Figure 6. Disability-adjusted life years indicator (DALY); (a) an explanation of the DALY indicator; $(\mathbf{b}, \mathbf{c})$ geographical variation of the DALY indicator to 100,000 inhabitants: (b) due to the extent of caries, regardless of the sex and age of the patients; (c) due to the extent of edentulousness, regardless of the sex and age of the patients.

The concept of the Dentistry Sustainable Development (DSD) > 2020 model includes all treatment activities undertaken by dentists, with full respect for real, possible, and necessary preventive actions, but not exclusive ones. Contemporary dentistry, apart from prevention, covers a total of five main branches covered by the principle of five Main Activities of Dentistry (5MAD) [36] (Figure 7b), where endodontics plays a prominent role as one of the several dentistry branches presented there, which should be considered interventionist dental branches. "The fifths rules" are an original approach, which is a modification of the assumptions of the behavioral strategy based on the idea of the Deming Plan-Do-Check-Act (PDCA) cycle illustrating the basic principle of continuous improve- 
ment [77]. In the case of evidence-based clinical caries treatment, due to the visual changes in enamel, dentin, and pulp, three caries advancement stages can be distinguished [78,79]. illustrated by the so-called caries continuum and the International Caries Detection and Classification System (ICDAS) [22,39,80,81]. Professional dental care requires an assessment of the risk of caries development for each patient. The caries development pyramid diagram (CDP) (Figure 7c) presents the different methods of the methodological approach, ranging from background level care (BLC) through preventive treatment options (PTO) to operative treatment options (OTO) [82-84]. One of the "Fifths rules" is for the 5D Caries Management Cycle Rules (CMCRs). On the evidence, especially in the early stages, this cycle covers the basic cyclical steps of 5D Caries Management Cycle Rules 5D (CMCRs) (Figure $7 d$ ):

Detect changes;

Define the activity of changes;

Dosing and assessing the scale of changes and their activity;

Decide on an individual patient care plan;

Perform the right intervention at the right time.

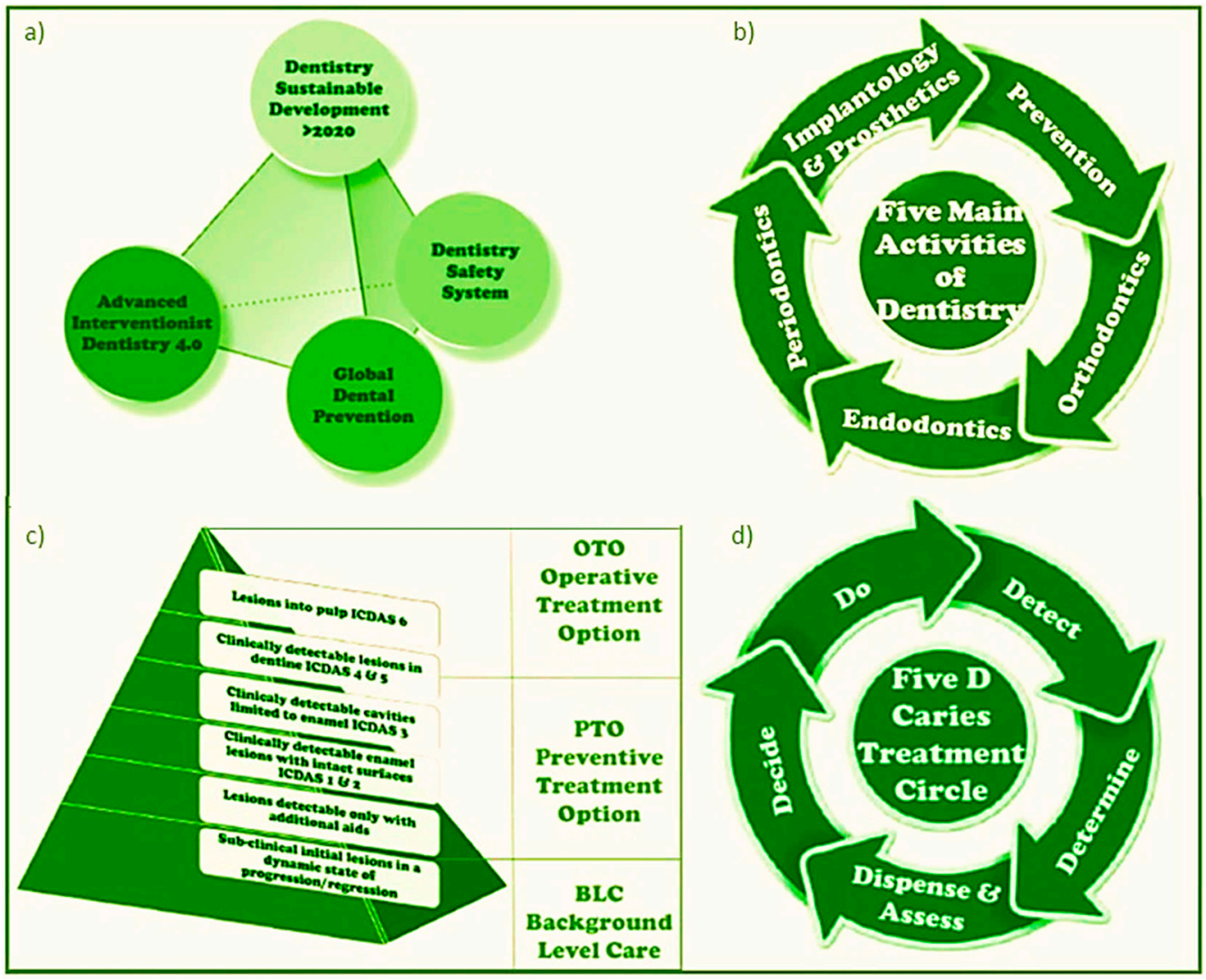

Figure 7. Models relating to dentistry: (a) sustainable development of dentistry; (b) the rules of the five main activities of dentistry (5MAD); (c) caries development pyramid (CDP) with indications from primary care (BLC) to preventive treatment options (PTO) and surgical treatment options (OTO); (d) 5D caries management cycle (CMCRs) principles for continuous improvement of the patient's oral health.

According to ICDAS $[78,79]$ and the patient's pain symptoms, endodontic treatment may be undertaken as an alternative to dental extraction in the case of at least the third stage of caries advancement. For health and aesthetic reasons, dentists prefer endodontic treatment to extraction [85,86]. Clinically, there are reversible pulpopathies and pulp necrosis among pulp diseases and irreversible pulpopathies that can be treated endodontically $[87,88]$. Pulp necrosis is associated with the occurrence of a latent infection focus in the 
oral cavity for many years, most often without pain, in contrast to irreversible pulpopathy, manifested by severe spontaneous pain that requires the assistance of a dentist. Endodontic treatment is becoming more and more common, among others due to the increase in health awareness of societies [89], promotional activities in many countries [89], measures taken to eliminate negligence in preventing caries [90], and the intensification of problems in the face of aging societies and prolongation of human life [91]. Therefore, by 2026, the endodontics market is expected to grow to USD 2.1 billion with a CAGR of $4.1 \%$ [90,92].

Regardless of the aesthetic motivations, endodontic treatment aims to preserve the treated tooth as a pillar in the stomatognathic system, which allows it to assume a natural dental implant function. Endodontic treatment consists of preparing the inside of the tooth, removing the pulp complex from occlusal at the pulp horns to the apical foramina [93], and replacing a living tissue with a substitute biocompatible filling material. As a result of the root canal preparation, caries and the previously made restorations are completely removed, especially if they were made incorrectly.

The anatomical features of the treated tooth and the surrounding tissues require detailed analysis, including the crown part, the pulp chamber, and the root pulp, before qualifying the tooth for endodontic treatment. It is also necessary to identify the orifices of all root canals in the pulp chamber. The dentist undertakes further actions consisting of [94] qualifying the teeth for endodontic treatment according to the procedure mentioned above, removing the roof of the pulp chamber, identifying the mouth of the pulp chamber and the bottom of the root canal opening, and instrumenting the root canals. It is necessary to clean and, in turn, shape the root canals with care not to damage the coronal enamel and dentin.

Figure 8 presents a set of rules for pre-access analysis, the technique of access and orifice location, and the laws of centrality, concentricity, color change, symmetry, orifice location, and floor anatomy regarding the qualification of teeth for endodontic treatment based on the analysis of the anatomy of the treated tooth and the surrounding tissues [95-97]. Radiographic and CBCT studies are used to measure the distance between the furcation and the cusp tip and the cusp tip-pulp floor distance CPFD to prevent chamber perforation in the furcation [98].

\begin{tabular}{|c|c|c|c|c|c|}
\hline \multicolumn{6}{|c|}{ The Process of eleaning and shaping the pulp eornptes } \\
\hline \multirow{10}{*}{ 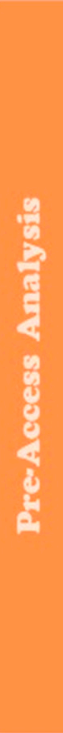 } & The Law of Centrality & \multirow{10}{*}{$\begin{array}{l}8 \\
\frac{8}{8} \\
\frac{8}{8} \\
\frac{3}{3} \\
\frac{3}{3} \\
\frac{3}{4}\end{array}$} & \multirow{10}{*}{$\begin{array}{l}\text { Step } 1^{\text {st }} \\
\text { All defective } \\
\text { restorations and caries } \\
\text { should be removed } \\
\text { Step } 2^{\text {nd }} \\
\text { Radiograph of calcified } \\
\text { canals in a molar } \\
\text { Step } 3^{\text {rd }} \\
\text { Using different burs to } \\
\text { unproof the pulp } \\
\text { chamber should be } \\
\text { completing access }\end{array}$} & \multirow{10}{*}{ 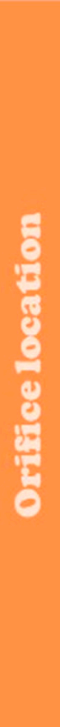 } & The Law of Color Change \\
\hline & \multirow{4}{*}{$\begin{array}{l}\text { Cut specimens showing Law of } \\
\text { Centrality Loction of initial } \\
\text { penetration point based on the } \\
\text { cementoenamel junction CEJ } \\
\text { perimeter } \\
\text { The Law of Concentricity }\end{array}$} & & & & $\begin{array}{l}\text { The color of the pulp chamber floor is darker } \\
\text { than the walls }\end{array}$ \\
\hline & & & & & \multirow{4}{*}{$\begin{array}{l}\text { The Laws of Sy mmetry } \\
\text { The diagrams of the Laws of Symmetry } 1^{\text {st }} \\
\text { and } 2^{\text {nd }} \\
\text { Cut specimen showing the vertices on the } \\
\text { pulp chamber floor }\end{array}$} \\
\hline & & & & & \\
\hline & & & & & \\
\hline & \multirow{5}{*}{$\begin{array}{l}\text { Step } 1^{\text {st }} \\
\text { Cut specimens showing Law of } \\
\text { Concentrity } \\
\text { Step } 2^{\text {nd }} \\
\text { Periodontal probing to locate the } \\
\text { cementoenamel junction CEJ } \\
\text { determining angulation with } \\
\text { radiograph; note mesial tipping of } \\
\text { the maxillary second molar } \\
\text { measuring the occlusal-furcal } \\
\text { distance }\end{array}$} & & & & \\
\hline & & & & & The Laws of the Orifice Location \\
\hline & & & & & $\begin{array}{l}\text { The diagrams of the Laws of Orfice Locations } \\
\qquad 1^{\text {st }} \text { and } 2^{\text {nd }}\end{array}$ \\
\hline & & & & & The Laws of Floor Anatomy \\
\hline & & & & & $\begin{array}{c}\text { Location of the third orifice on a maxillary } \\
\text { premolar using the Laws of Floor Anatomy } \\
\text { Floor anatomy showing } 2 \text { orifices in a } \\
\text { mandibular molar }\end{array}$ \\
\hline
\end{tabular}

Figure 8. A set of rules and laws regarding the qualification of teeth for endodontic treatment based on the analysis of the anatomy of the treated tooth and the surrounding tissues. 
A root canal requires preparation, followed by apically, laterally, and coronally sealing by obturation to prevent the spread of bacteria and possible toxins from the root canal towards the root apex [99-101] and also from saliva [102]. Progress in the field of endodontics has been taking place in the world since 1836 when E. Maynard removed the pulp from the inside of the tooth for the first time [103]. Techniques for the development and obturation of root canals are systematically developed [97], although the pace of these changes is not significant, and the changes have been noticeable over the last half-century. It should be noted that significant progress was made possible by introducing rotating tools to prepare root canals, and very significant progress was achieved by introducing Nitinol tools into endodontic practice after the end of the 20th century [104]. The publication mentioned above [104] comprehensively analyzes this problem; therefore, this paper does not broadly develop this problem. Nitinol, as an alloy of nickel and titanium with equilibrium or strongly similar to atomic balance concentration of both of these elements with a very high metallurgical purity and produced by vacuum smelting, shows the effect of superelasticity and shape memory, thanks to which it allows drilling in strongly curved root canals without fear of breaking the tool, enabling the prevention of the strong iatrogenic complications associated with it [104]. The importance of Nitinol in endodontics is also confirmed by numerous practical experiences and studies of specific tools made of this material performed by dentists, presented, e.g., in the works $[105,106]$.

Some of these changes may be of historical importance now but are generally illustrated as an umbrella for endodontic development and obturation methods [86] (Figure 9a). Among these methods, the diagram of the most modern Thermo-Hydraulic Condensation technique [107-110] was presented in detail, filling root canals with the use of System B, introduced about 20 years ago, enabling the lateral canals to be filled to a greater extent and consisting of increasing the plasticity time of such filling materials as, e.g., based on gutta-percha or resilon, under the influence of temperature and pressure generated during this procedure, by the use of appropriate equipment (Figure $9 \mathrm{~b}-\mathrm{j}$ ).

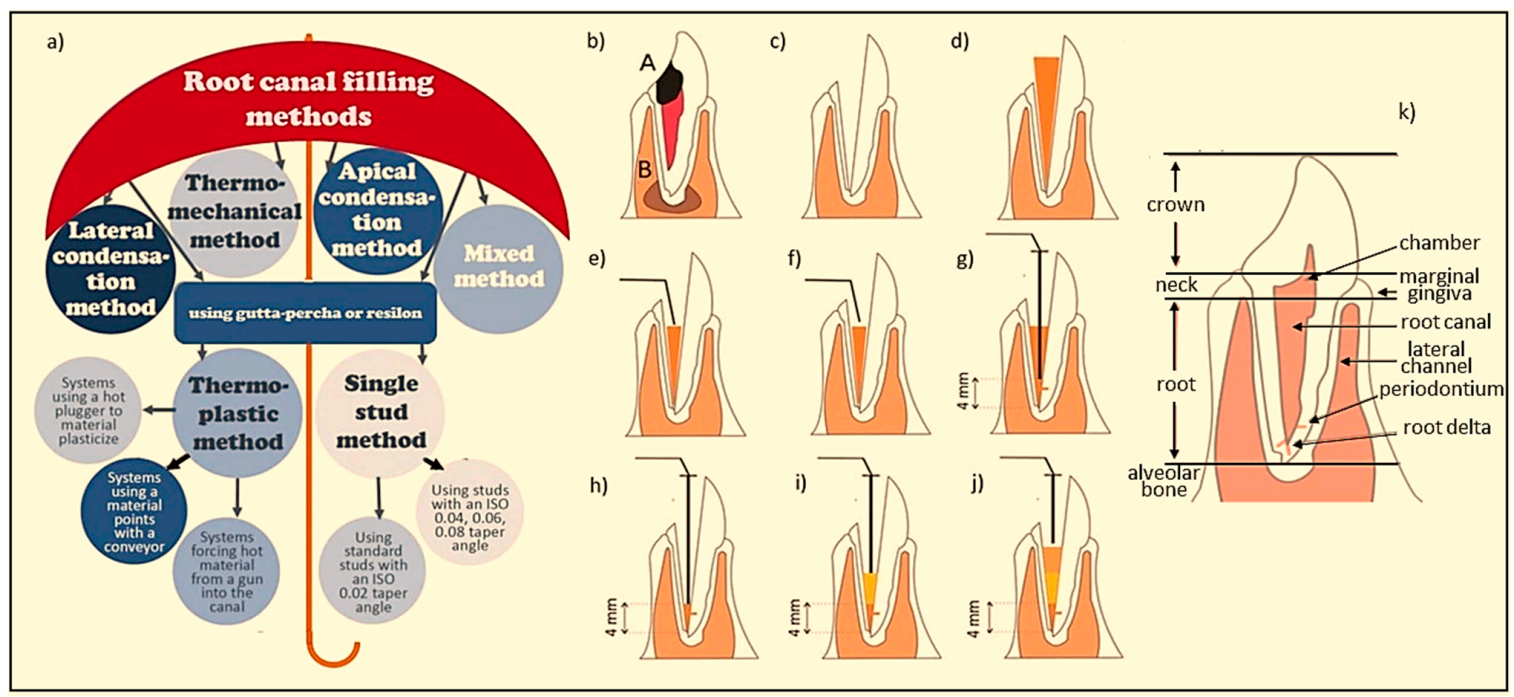

Figure 9. Scheme of root canal obturation methods in endodontics: (a) classification of methods in the form of an umbrella; (b) dead pulp due to a carious lesion (A) with a periapical lesion (B); (c) evacuation of the ventricular root pulp and conical root canal preparation; (d) fitting the main cone to the root canal; (e) cutting off the main stud with a heated plugger; (f) condensation at the mouth of the severed main cone with a cold Buchanan plugger; (g) plasticizing the main stud by introducing the heated plugger to a depth $4 \mathrm{~mm}$ less than the working length and cutting off the excess stud; (h) condensation of the plasticized main cone with a cold Buchanan plugger; (i) filling 1/3 of the central part of the channel with liquid filling material plasticized outside the channel and then condensing the material with a cold Buchanan plugger as in (h); (j) final filling of the channel with liquid filling material plasticized outside the channel and then condensation of the material with a cold Buchanan plugger as in point (h); $(\mathbf{k})$ the functions of the tooth pulp before the onset of caries symptoms. 
For analyzing the conditions for the development of root canals and obturation methods, the so-called "Digital twins" as an approach appropriate for Industry 4.0 [111-144] and the resulting idea of Dentistry 4.0 could be used [145-147]. It is possible to perform experiments in virtual space and theoretical analysis with methods usually used in management science, and especially in foresight research as part of knowledge management.

One of the criteria for the effectiveness of the development and obturation of root canals is the quality and tightness of the root canal filling, for which the materials engineering research apparatus and the achievement of technological foresight of surface engineering were used. The virtual analysis used, among other things, the methodology of procedural benchmarking and comparative analysis with the use of contextual matrices, as tools often used previously by the authors of this article, including for the assessment of surface engineering technology [115,148-165], as well as dental issues [71,92,96,97].

Criteria for the multi-criteria evaluation of generalized indices characterizing the potential and attractiveness of both methods of elaboration and obturation of root canals were defined (Figures 10 and 11) [92].

Each of the criteria was assigned weights reflecting their importance; for each set of criteria, they were summed up to one, and then the assessment of these methods according to previously adopted criteria in an appropriately selected scale was made [92]. The basis for both the selection of criteria and assigning them appropriate weights, and above all individual assessment in each criterion, is the use of expert knowledge, which consists of the life and professional experience of experts. It is possible to use the knowledge of at least one expert, which would not be a mistake, while the assessment can be objectified by consulting a large group of experts, provided that each of them is close to the issues assessed.

A ten-point unipolar positive interval scale without zero was used, where 10 is the maximum possible rating and 1 is the minimum rating (Figure 12). This universal scale of relative states has been used so far in many previous studies by the authors of this article $[71,92,96,97,115,148-165]$.

The numerical rating of each of the methods for the development and obturation of root canals, granted under each of the criteria, should be multiplied by its weight, and then the individual partial results summed up for each set of criteria, thus obtaining a weighted average constituting a tool for comparative analysis. This allows the determination of the significance of a given method of the proper development and obturation of root canals compared to others.

The development of contextual matrices was inspired by the portfolio methods used to characterize the portfolio of products offered to the client by the company, drawing on the prototype developed by the Boston Consulting Group (BCG) [166]. They have become extremely popular in management sciences, where the star and the cash cow are synonymous with the success of dominant market entities; the question mark does not cancel the venture but does not guarantee success, while the dog is a symbol of a failed venture. Using such a selected methodological apparatus, allowing for a comparative analysis of adequately elaborating and obturating root canals, it is also possible to define critical (priority) methods of key importance and/or the best development prospects. 


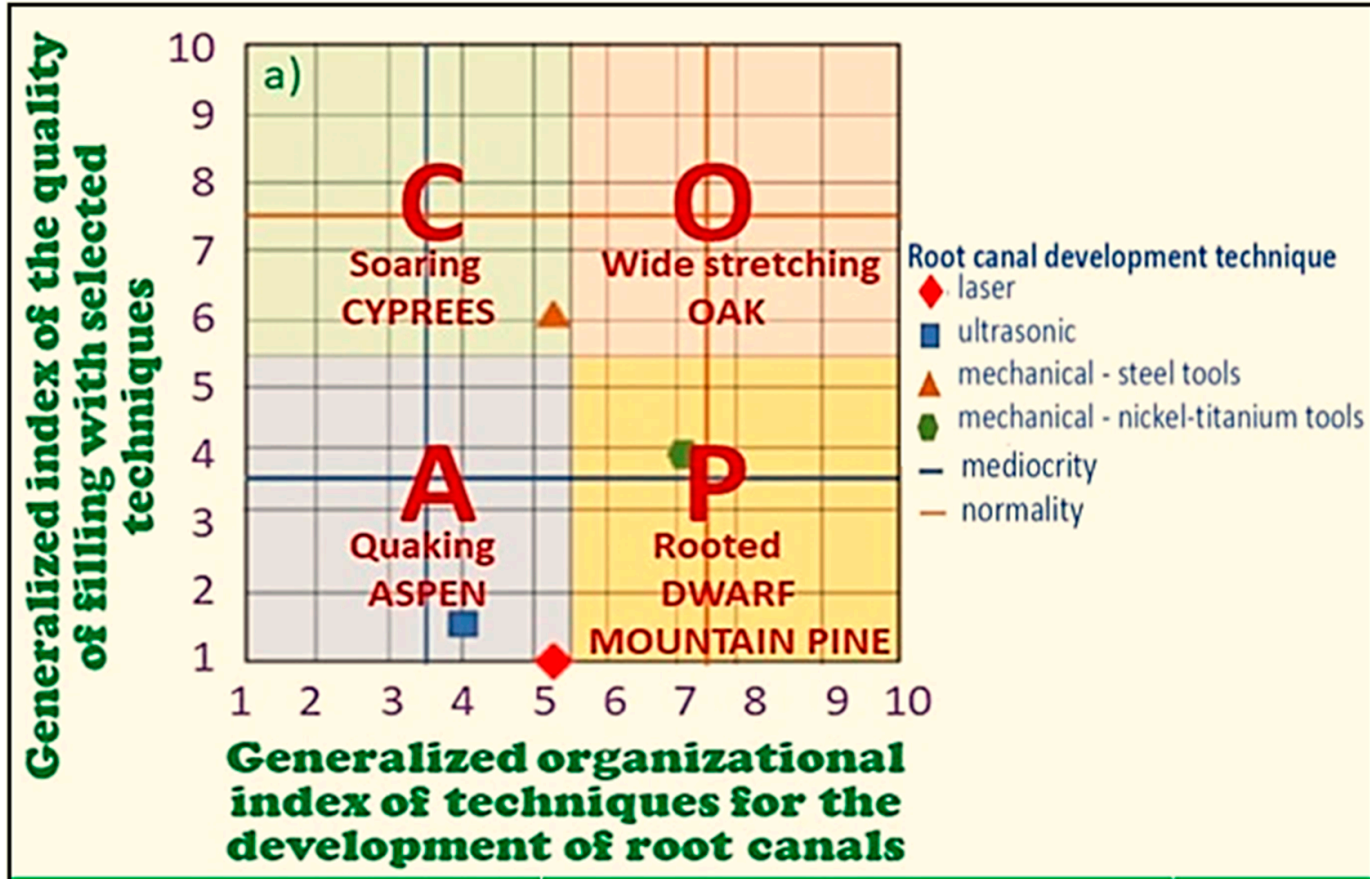

b)

General descriptors -

techniques for the development

of root canals
Criteria for determining the generalized

quality index of the root canal filling with selected techniques
Griteria for determining

the

generalized

organirational

index of

techniques for

the

development of root canals

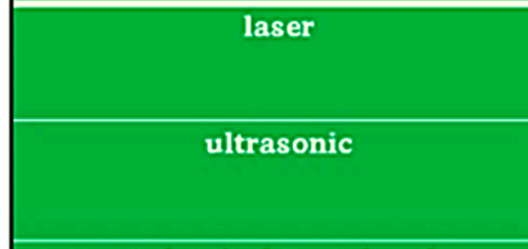

mechanical - steel tools

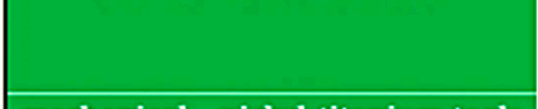

mechanical - nickel-titanium tools

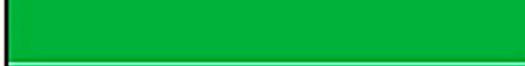

Weight

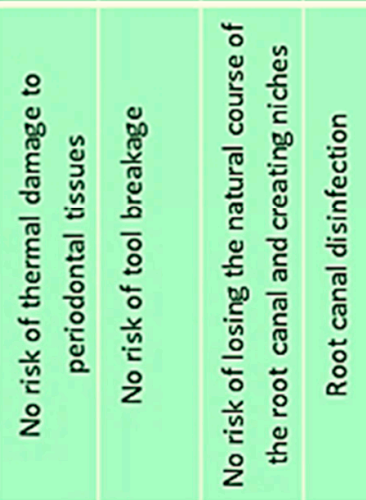

0.3

0.2

0.1

0.1

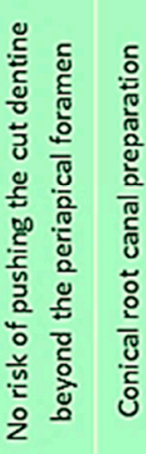

0.2

0.1

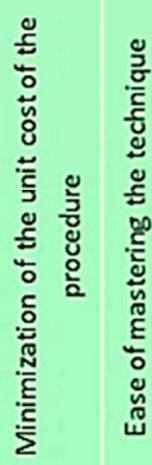

0.5

Figure 10. Contextual matrix of attractiveness of (a) virtual contextual analysis regarding methods of root canal preparation and a set of adopted criteria for expert assessment $(\mathbf{b})$. 


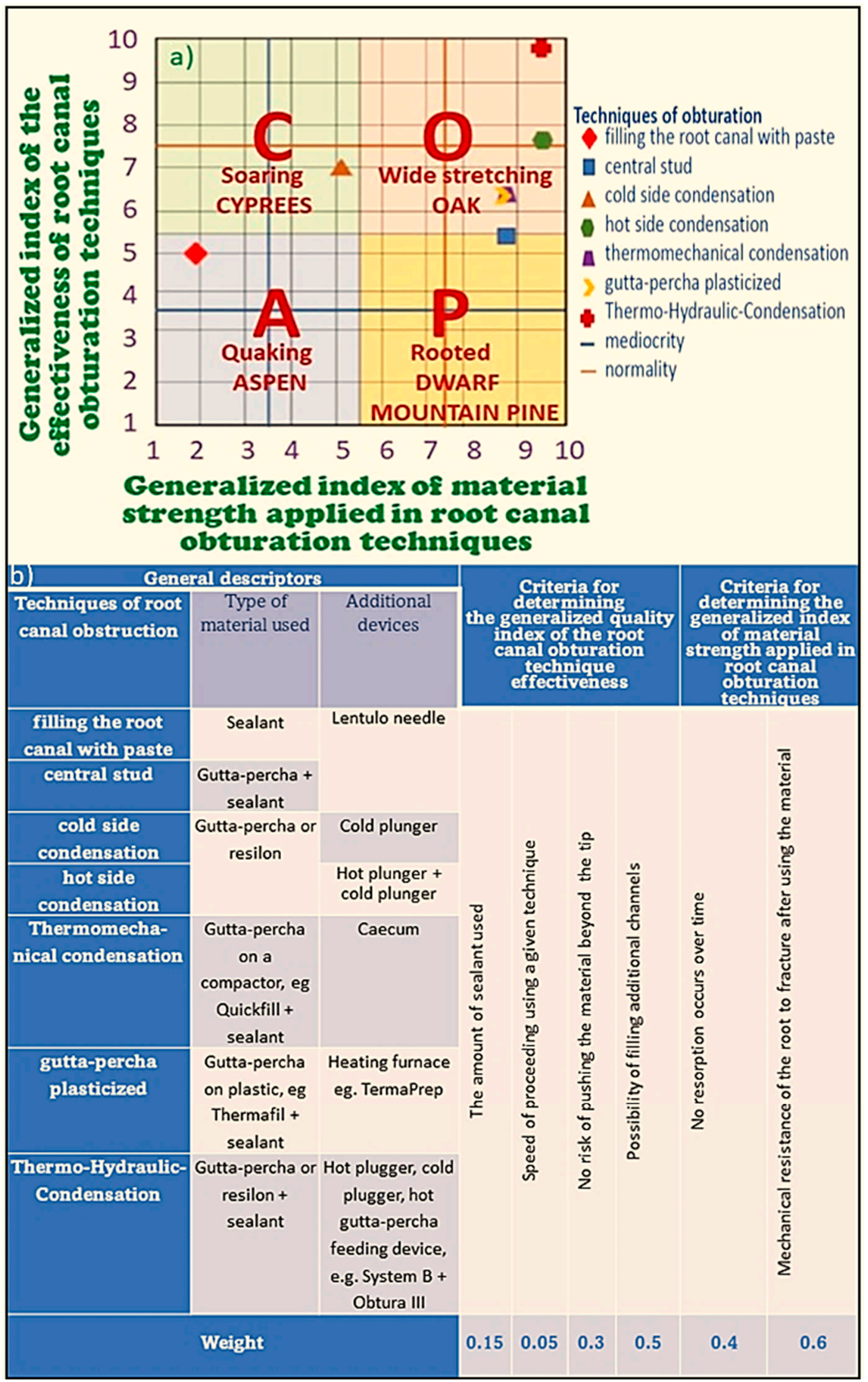

Figure 11. Contextual matrix of attractiveness (a) of virtual contextual analysis concerning methods of root canal obturation and a set of criteria for expert assessment $(\mathbf{b})$. 


\begin{tabular}{|c|c|c|c|c|}
\hline \multirow{2}{*}{$\begin{array}{c}\text { Numerical value } \\
10\end{array}$} & \multicolumn{2}{|c|}{ Class discriminant } & \multirow{2}{*}{$\frac{\text { Level }}{\text { Excellent }}$} & \multirow{2}{*}{ perfection } \\
\hline & 0.95 & $\nLeftarrow$ & & \\
\hline 9 & 0.85 & $\longleftarrow$ & Very high & \multirow{3}{*}{ normally } \\
\hline 8 & 0.75 & $\longleftarrow$ & High & \\
\hline \multirow{4}{*}{$\begin{array}{l}7 \\
6 \\
5 \\
4\end{array}$} & 0.65 & & Quite high & \\
\hline & 0,55 & & Moderate & \multirow{6}{*}{ mediocrity } \\
\hline & 0.45 & 4 & Medium & \\
\hline & 0.35 & $\leftarrow$ & Quite low & \\
\hline 3 & 0.25 & & Low & \\
\hline 2 & 0.15 & 4 & Very low & \\
\hline 1 & 0.05 & & Minimal & \\
\hline
\end{tabular}

Figure 12. Universal scale of relative states.

Contextual matrices are used to position and evaluate the usefulness of individual methods or methods of developing and obturating root canals from among those included in the analysis in endodontological treatment, as a tool for comparative graphical analysis, which has already been generalized and used so far to analyze many problems [36,71,92,96,97,111,115,148-165,167-176].

Generalized dendrological value matrices of methods and modes, including technologies, make it possible to position these methods and modes depending on their generalized potential and generalized attractiveness. Generalized potential is the real objective value of a given method or mode, while generalized attractiveness reflects its subjective perception among its potential users. The generalized potential of a given group of methods or modes, expressed using the universal scale of relative states, plotted on the horizontal axis of the dendrological matrix, results from a multi-criteria analysis carried out based on expert assessment. It considers appropriate proportions of the generalized potential: creative, applicative, qualitative, developmental, and technical, expressed by an appropriately selected set of criteria, which were assigned appropriate weights. On the vertical axis of the generalized dendrological matrix, the generalized attractiveness of a given group of methods and modes was plotted, being the weighted average of expert assessment made based on detailed criteria corresponding to economic, market, humanistic, natural, and natural systemic attractiveness.

Based on the expert analyses [92], Figure 13 show the criteria for evaluation of the research material depending on the variants of development and obturation of the root canal.

Depending on the value of the generalized potential and the level of generalized attractiveness, which were determined within the expert assessment [92], each of the analyzed methods or modes was placed in one of the matrix quarters distinguished in the generalized dendrological matrix. Depending on the location of each of the analyzed methods or modes in a given quadrant, one can conclude about their market or methodological success, respectively, as in the discussed case concerning endodontics. Methods or modes with high generalized potential from the range $(5.5 ; 10)$ and high generalized attractiveness from the field $(5.5 ; 10)$ are located in the quarter of the wide-stretching oak. This can ensure the future success and expansion, for example, of the market expansion of particular methods and modes used in endodontics. There is no method of treating root canals in this quadrant, but there are four obturation methods, i.e., the Thermo-Hydraulic Condensation technique, hot side condensation, and the thermomechanical condensation gutta-percha plasticized method. In the quadrant dwarf rooted mountain pine, where the generalized potential is large in the range $(5.5 ; 10)$, with limited generalized attractiveness in the field $(1 ; 5.5)$, success is highly probable but subject to additional commitment to improving attractiveness. In this quadrant, there is a method of rotating machining using tools made of a Nitinol alloy, and in the area of obturation, the central stud method. There are methods or modes with high generalized attractiveness in the range $(5.5 ; 10)$ in the soaring cypress quarter, but with 
limited generalized potential in the range $(1 ; 5.5)$. Because, in such a case, the advantages are apparent and could obscure the real application possibilities, therefore success cannot be ruled out; although it is possible, it is not certain. In this quadrant, among the methods of root canal preparation, there is mechanical treatment with the use of steel tools, while in the field of obturation, there is the cold side condensation method. The quadrant quaking aspen, where both the generalized potential and generalized attractiveness are in the range $(1 ; 5.5)$, indicates the weakest methods or modes that indicate the need to abandon their practical application, as they will not ensure success. The methods completely disqualified in root canal preparation include laser and ultrasonic treatment. In contrast, in the field of obturation methods, the use of pastes for filling root canals should be included. The results of virtual analyses [92] obtained in this way indicate a limited range of possibilities for the development and obturation of root canals under practical conditions.

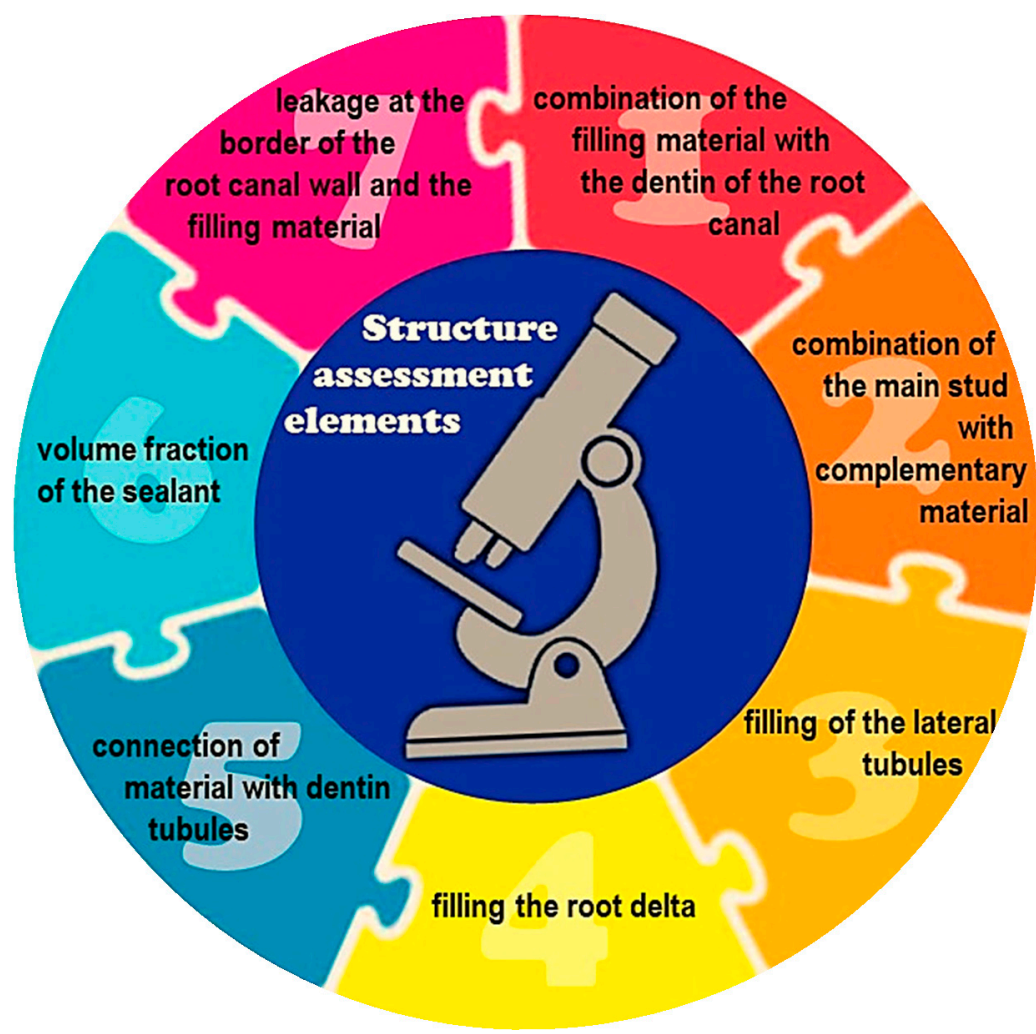

Figure 13. Criteria for the evaluation of the research material depending on the variants of development and obturation of the root canal.

There are essential factors that determine the correctness of endodontic treatment. The preparation of the root canal presented above depends not only on the dentist's experience but also on selecting tools. The second factor is also the technique of obturation discussed above, which depends mainly on the experience and skills of the dentist. Endodontic treatment is based on the optimal use of the filling material, ensuring the best sealing of the root canal with an appropriately given and required shape after removing the contents inside it and after its careful disinfection.

As experiments have shown, endodontics' goal is only "asymptotic" and hypothetic to produce a monoblock as a solid, bonded, continuous dentin material from one root canal wall to another, usually mechanically forming a homogeneous unit with the root dentin [177]. A strong connection of the monoblock elements with the reinforcing material is required, and the modulus of elasticity of the monoblock and this material should have similar values [178]. There are three types of monoblocks depending on the number of interfaces between the bulk material core and the binding substrate. The primary 
monoblock shows a single interface between the material and the root canal wall, as in the case of Hydron [179], MTA mineral trioxide aggregate [180,181], bio-gutta, and polyethene fiber core systems [97]. The secondary monoblock has two points of contact, between the core material and the cement, and the other between the cement and dentin, as in the case of gutta-percha-based filling materials due to the presence of a sealant [182], despite a too low modulus of elasticity [183-185], and adhesives as substitutes for gutta-percha [186], as well as resilon with a methacrylate-based sealant, although strong polymerization shrinkage causes leaks [168] and makes the monoblock's existence impossible. Tertiary monoblocks have a third boundary between the filler material and the bonding medium such as EndoRez or resin-coated gutta-percha with CLEARFIL LINER BOND 2V binder $[187,188]$ or using ActiV GP $[187,189]$. It was generally shown in $[190,191]$ that the monoblock concept is not true, despite its stable position in the literature. Schematically, the monoblock concept is presented in Figure 14.

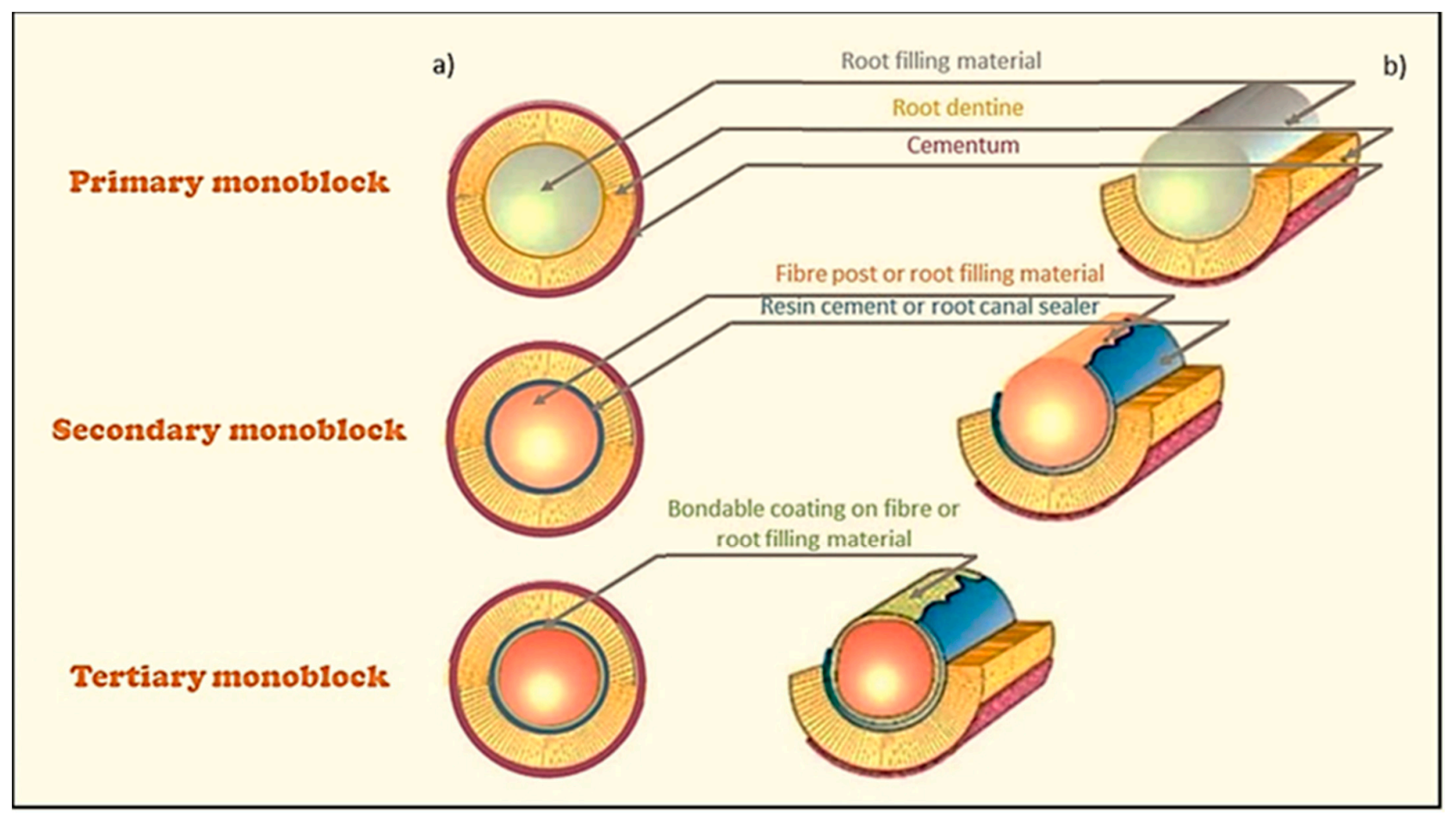

Figure 14. Diagram of monoblock construction in endodontics: (a) cross-section of a filled tooth root; (b) half-section of a tooth fragment filled with filling material with or without intermediate layers in the axonometric projection.

\section{Material for Research and Scope of Experimental Research}

The main factor determining the effectiveness of endodontic filling is the selection of filling material and an adequate obturation method. According to the program described in detail in the works $[36,96,97]$, the published detailed results of studies conducted separately for various materials were used. Eighty human teeth extracted for medical indications but not affected by caries were selected for the study. Among them, five groups of 16 teeth were distinguished [92].

Root canals were prepared with hand tools (ProTaper-Dentsply/Maillefer) and alternatively in appropriate groups with K3 rotary tools (Sybron Endo) using the X-Smart endodontic micromotor (DentSply/Maillefer) with each root canal recapitulation using the Keer tool. During the mechanical preparation of the root canals, a RC-Prep lubricant (Premier) containing glycerin, sodium edetate, and urea peroxide was used, and irrigation was performed alternately with $2.25 \%$ sodium hypochlorite solution and $0.9 \%$ saline solution between the subsequent insertion of the instruments into the root canal. 
After processing, the examined teeth were filled with material based on gutta-percha (three groups) and resilon (two groups) by cold side condensation and thermoplastic using the Thermo-Hydraulic Condensation technique using a Buchanan plugger (SybronEndo) and an Obtura III type system (SybronEndo) fixed at $160{ }^{\circ} \mathrm{C}$. In the case of the material based on gutta-percha, a thermoplastic method was also used to use a Thermafil system with the ThermaPrep Plus furnace and a Therma-Cut drill without water cooling at a speed of 300,000 rpm. After filling them with filling material, the mouths of the root canals were secured with Ketac Molar glass-ionomer cement (3M ESPE), and the teeth were stored for seven days at room temperature and wrapped with gauze soaked in physiological saline in a sealed container.

The gutta-percha-based filling material used in the research is used in endodontics in the form of studs or pellets, in which the pure $\beta$ form of gutta-percha constitutes $18-22 \%$, and the rest is a mixture of $59-75 \%$ zinc oxide, which improves plasticity and reduces brittleness, $1.1-31.2 \%$ of barium and strontium sulfate, ensuring X-ray impermeability and therefore the possibility of identification with this method, as well as $1-4.1 \%$ of other polymers and wax [36]. Gutta-percha studs and pellets (DentSply/Maillefer) and AH Plus sealant (DentSply/Maillefer) from Dentsply Maillefer, Ballaigues, Switzerland were used.

Synthetic filler material based on polyester materials consists of an organic part constituting a matrix of methacrylate resin and about $65 \%$ of inorganic fillers, including bioactive glass, barium sulfate, and bismuth oxychloride impermeable to X-rays [192-198]. This material was first introduced by Resilon Research, LLC, Madison, CT, USA [193], and hence it is mainly known under the trade name resilon. The system also includes a dual-curing resin sealant containing about $70 \%$ calcium hydroxide, bismuth oxychloride, barium glass and silica filler, and a self-etching primer containing sulfonic acid-terminated functional monomer, HEMA 2-hydroxyelylmethacrylate, water, and a polymerization initiator [191,192,199,200]. RealSeal resilon studs and pellets (SybroEndo) from Sybron Dental Specialties, Orange, CA, USA and RealSeal sealant known as epiphany from Pentron Clinical Technologies, Wallingford, CT, USA were used.

After obturation and filling with filling material, the teeth were incised with a diamond disc on one side along the root, to a depth of $1 \mathrm{~mm}$, using a prosthetic handpiece. After immersion in liquid nitrogen, a longitudinal fracture was made. Each sample was sputtered with a thin layer of gold in a BAL-TEC SCD050 sputtering machine by Oerlikon Balzers to prepare for materialographic examinations in a scanning electron microscope. Preparations for testing were also made by decalcifying for 14 days in an aqueous solution containing $7 \%$ formic acid, 3\% hydrochloric acid, and $8 \%$ sodium citrate, and after rinsing under running water, they were immersed for $12 \mathrm{~h}$ and rinsed in $99 \%$ acetic acid. The samples were then rinsed with distilled water and dehydrated each time for $30 \mathrm{~min}$ in an aqueous solution of successively increasing concentrations of $25,50,70,90,95$, and $100 \%$ ethanol to be subsequently stored in methyl salicylate.

To assess the tightness of root canal filling using materials based on gutta-percha and resilon, attention was paid to seven elements of the research material evaluation depending on root canal preparation and obturation (Figure 15) [92].

The choice of the appropriate method for assessing tightness and the other aspects mentioned above in evaluating the research material are depending on the variants of development and obturation of the root canal. In work [92], an analysis of the weighted scoring method was carried out with the development of the "meteorologi-cal" contextual attractiveness matrix, which showed that among the methods of as-sessing tightness of root canal fillings, the highest values and a clear advantage over other methods in terms of effectiveness were given to visualization methods using materialographic microscopes (Figure 10). 

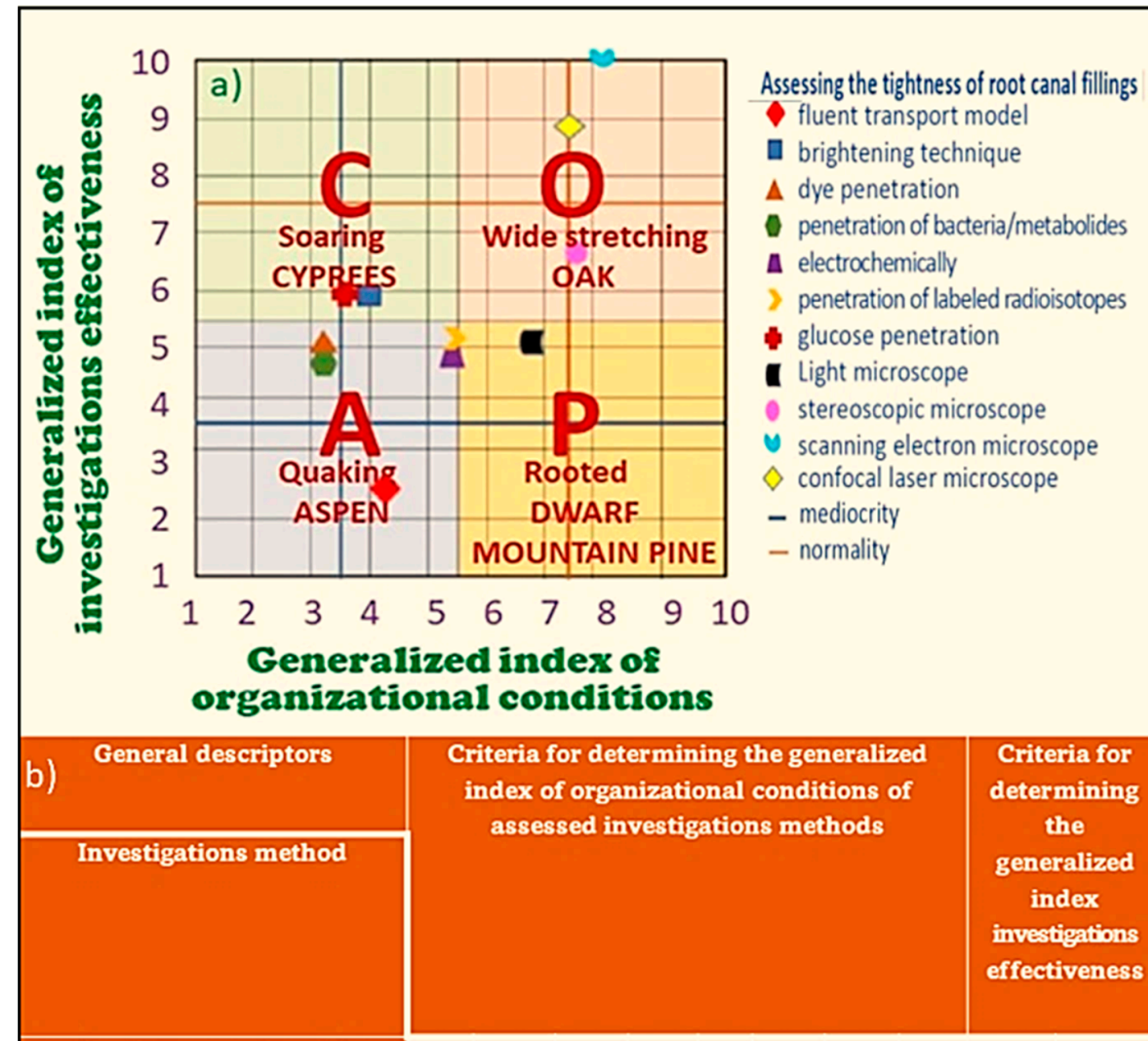

Criteria for index of organizational conditions of determining

the generalized index investigations effectiveness

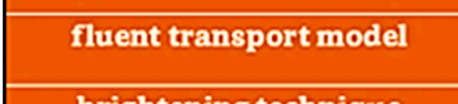

brightening technique

\begin{tabular}{|c|}
\hline dye penetration \\
\hline penetration of \\
bacteria/metabolides
\end{tabular}

\begin{tabular}{|c|}
\hline electrochemically \\
\hline penetration of labeled \\
radioisotopes \\
\hline glucose penetration \\
\hline light microscope \\
\hline stereoscopic microscope \\
\hline
\end{tabular}
scanning electron microscope
confocal laser microscope

\section{Weight}

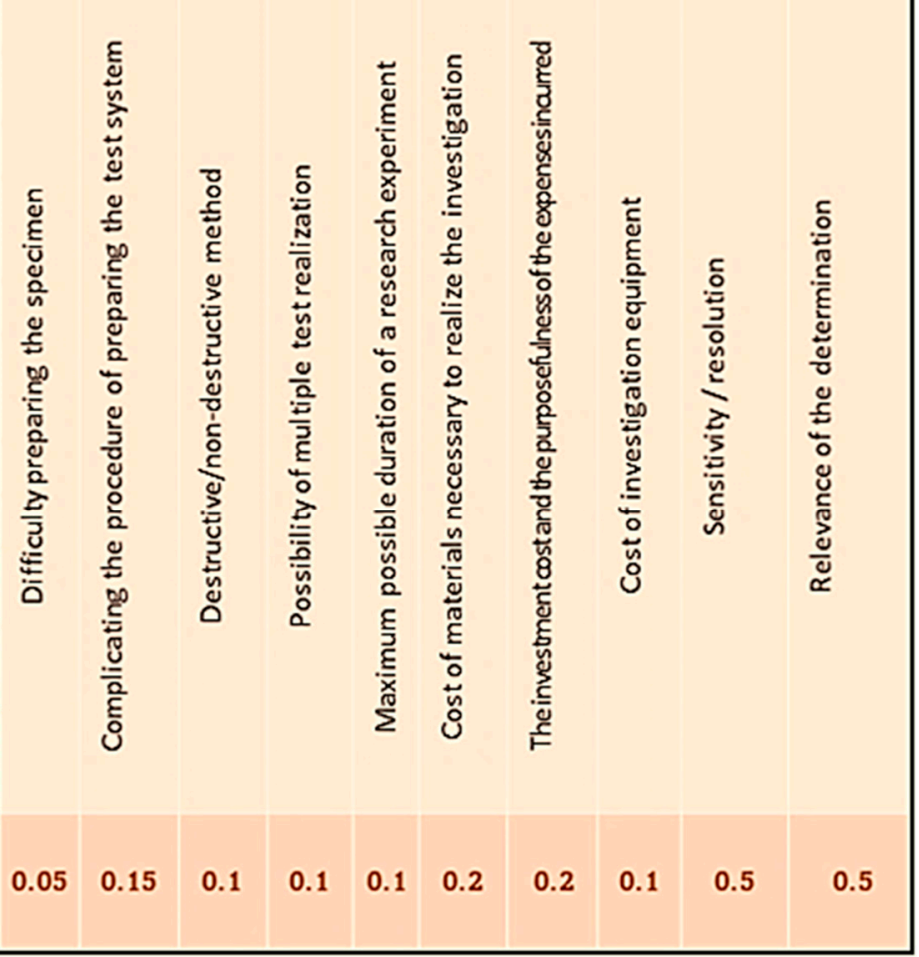

Figure 15. Contextual matrix of attractiveness (a) of the virtual contextual analysis regarding the selection of methods for assessing tightness of the root canal filling and a set of adopted criteria for expert assessment (b). 
These methods make it possible to obtain the required high resolution, ensuring the disclosure of structural details and the measurement of the changes that occur, as well as the location of the sealant and filling material in the root canal. It applies in particular to research with the use of all available materialographic microscopes, imainly the ZEISS LSM Stereo Discovery.V12 automated stereoscopic light microscope with the HRC camera and the SEM SUPRA 35 high-resolution scanning electron mi-croscope from ZEISS with the WDS, EDS spectrometer, and the EBSD TRIDENT cam-era. XM4 by EDAX. Therefore, the basic research discussed in this article was per-formed using methods appropriate for materialographic research $[96,97]$. These tests were performed in LSM with magnification up to $50 \times$ and in SEM in the range of mag-nifications up to $5000 \times$. The results of the research were digitally archived. Using SEM, measurements of the width of the slits were also made, and the results of these meas-urements were statistically processed, giving the mean value and standard deviation and analyzing the significance of the mean difference.

The results of the SWOT point analysis (strengths and weaknesses, opportunities, threats) were also compared, according to the previously described methodology and the results of analyzes contained in the works $[96,97]$, each time defining five key fac-tors relating to each aspect in this analysis, adequate to both analyzed filling materials. A contextual dendrological matrix, taken from the work [92] on endodontic filling materials, is also presented. The generalized dendrological matrix of filling materials used in endodontics is presented in the coordinate system generalized potential show-ing the real objective value of a given material—generalized attractiveness of these materials for endodontic treatment.

\section{Tightness of Root Canal Filling with Filling Materials Based on Gutta-Percha and Resilon}

In the stereoscopic light microscope, preliminary studies of the longitudinal fractures of the teeth filled with material based on gutta-percha (Figure 16G) and resilon (Figure 16R), respectively, were carried out, indicating that the root canal is tightly filled by the main stud connected to the root canal dentin with a relatively thick- or thin-layer intermediate sealant.

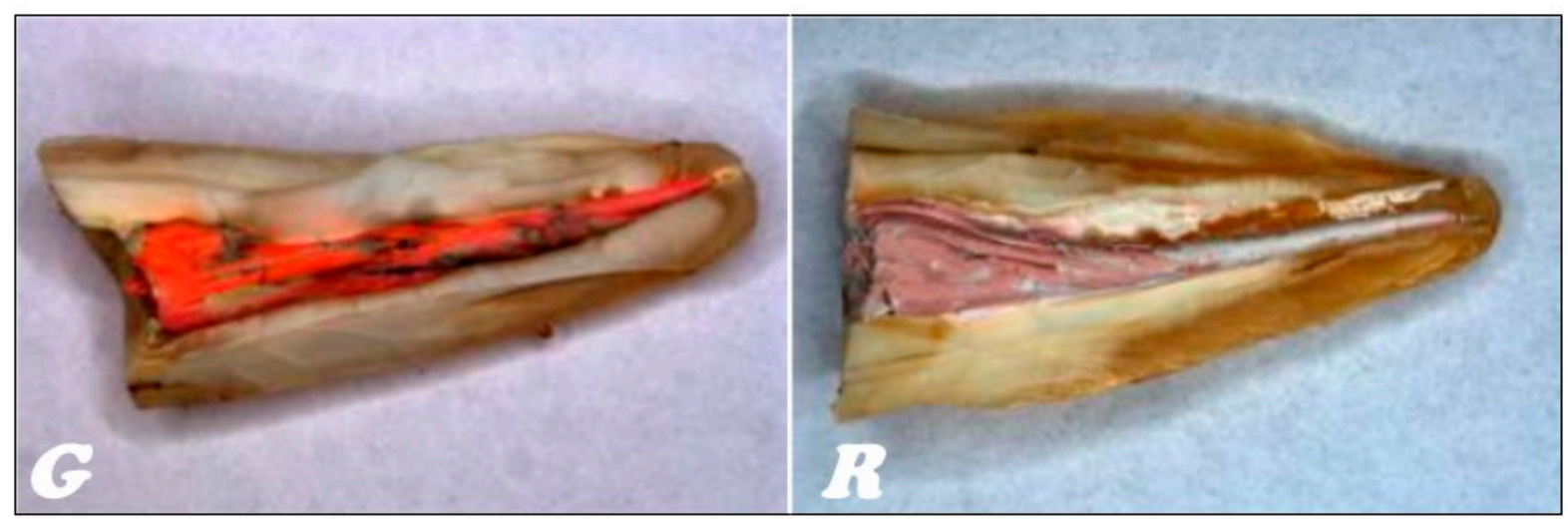

Figure 16. Longitudinal fracture of the tooth root filled by cold lateral condensation with material based on gutta-percha and sealant $(\mathbf{G})$ and resilon with sealant $(\mathbf{R})$; LCM.

Thanks to scanning electron microscopy, dentinal tubules' presence was revealed as the effectiveness of the endodontic treatment of teeth. The correct choice of filling material is significantly influenced by both the technology of root canal development and the obturation sealing materials used. These factors determine the quality of the root canal filling and the quality of the connection of the main stud of the filling material with the supplementary material.

In the cold obturation technique, the proportion of sealant tightly covering the filling material is relatively high, both when using a material based on gutta-percha and resilon (Figure 17). The sealant is used to fix the main stud and additional studs together. The sealant must surround the studs of the filling material on all sides. Local shortages of the 
sealant cause local non-adhesion of the material and leakages that significantly reduce the quality of endodontic treatment. The desired uniform filling encapsulating the root canal of any shape requires the correct connection of the central stud with additional studs. These studs are mechanically connected due to condensation and chemically bonded by a sealant.

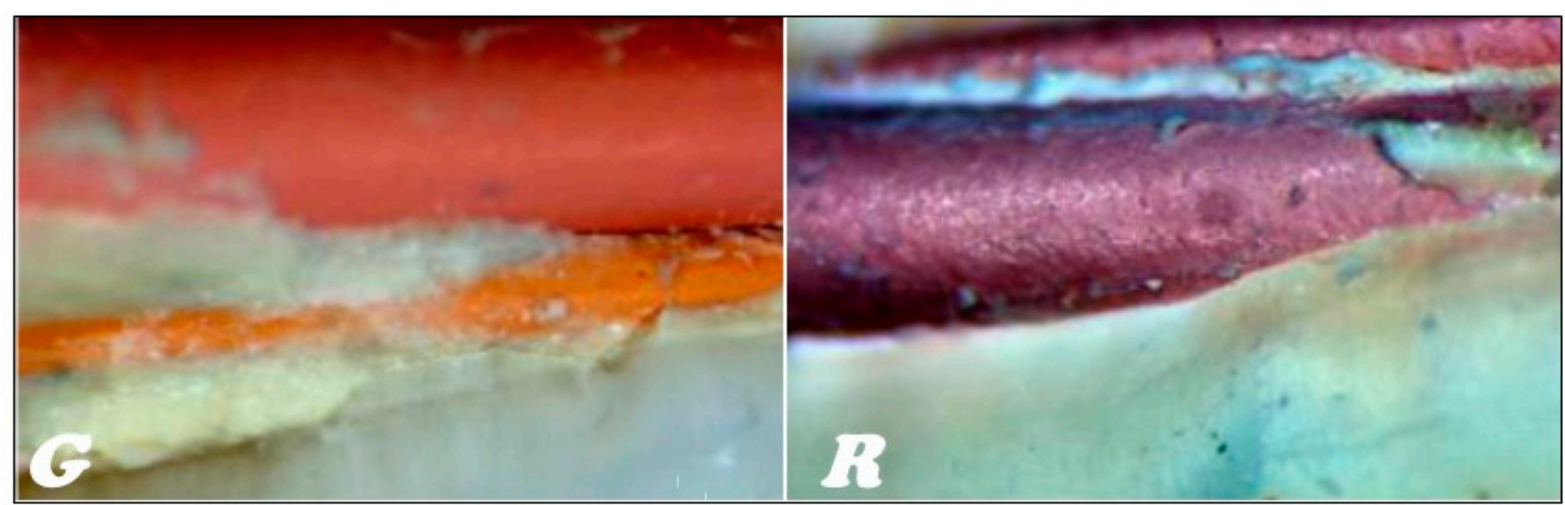

Figure 17. Middle section of the root canal sealed by cold lateral condensation $(\mathbf{G})$ using gutta-percha studs with a thick intermediate layer of sealant on the border of the dentin of the root canal and complementary studs and a thick intermediate layer of sealant on the border of the complementary studs and the central stud with visible leak (R) connection of the main stud made of resilon with the additional stud; LSM.

Unfavorable non-connection of the material occurs (Figure 18) if the sealant is present between the main stud and the additional studs. This effect is more often observed when resilon is used as a filling material than in the case of using a material based on gutta-percha. Similar effects of the delamination and separation of the filling material from the dentin of the root canal and the resulting leaks may be caused by an excessively thick layer of sealant, and therefore its share is too high.

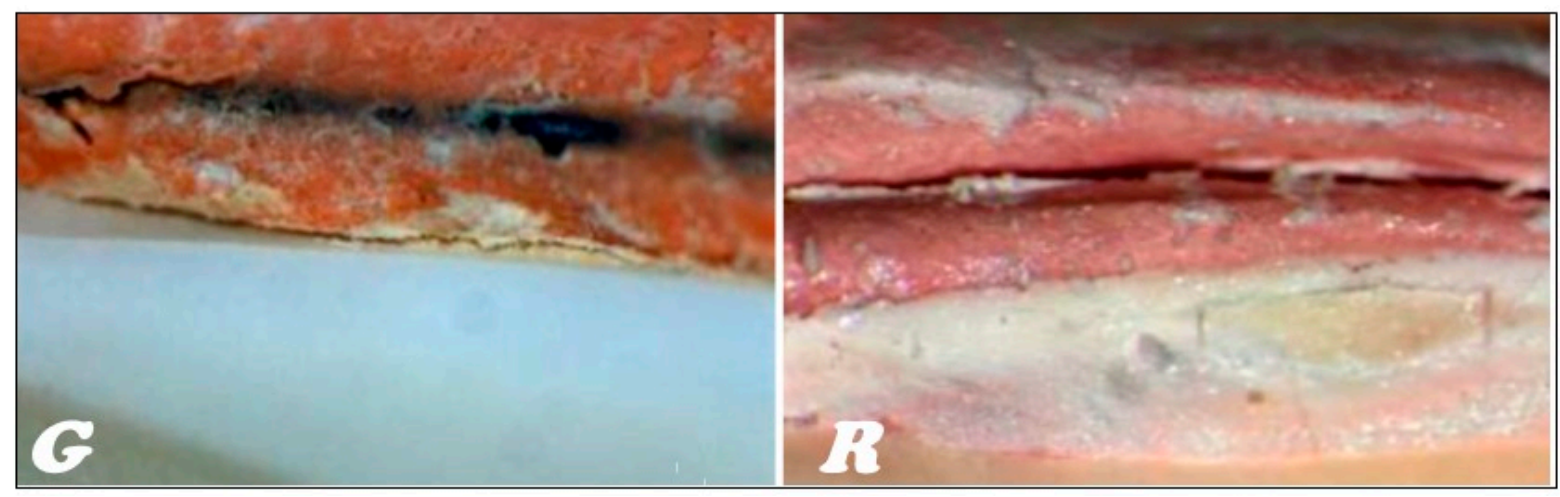

Figure 18. Leakage between the central stud and additional studs of the filling material due to insufficient share of the sealant and thus non-fusing of the central and additional studs, and with the dentin wall after obturation with material based on gutta-percha $(\mathbf{G})$ and resilon $(\mathbf{R})$; LSM.

Thanks to the scanning electron microscope tests, the presence of dentinal tubules was revealed as the smallest anatomical structures in teeth's longitudinal or transverse sections, respectively. The tightness of the connection of the filling material with the dentin of the root canal after obturation using the cold lateral condensation method was demonstrated. The disinfection of the internal space was confirmed, and the tight, three-dimensional hermetization was manifested by the correct combination of dentin and filling material based on gutta-percha or resilon, respectively, with a thin intermediate layer of sealant, closely adjacent to the border of the root canal wall (Figure 19). 


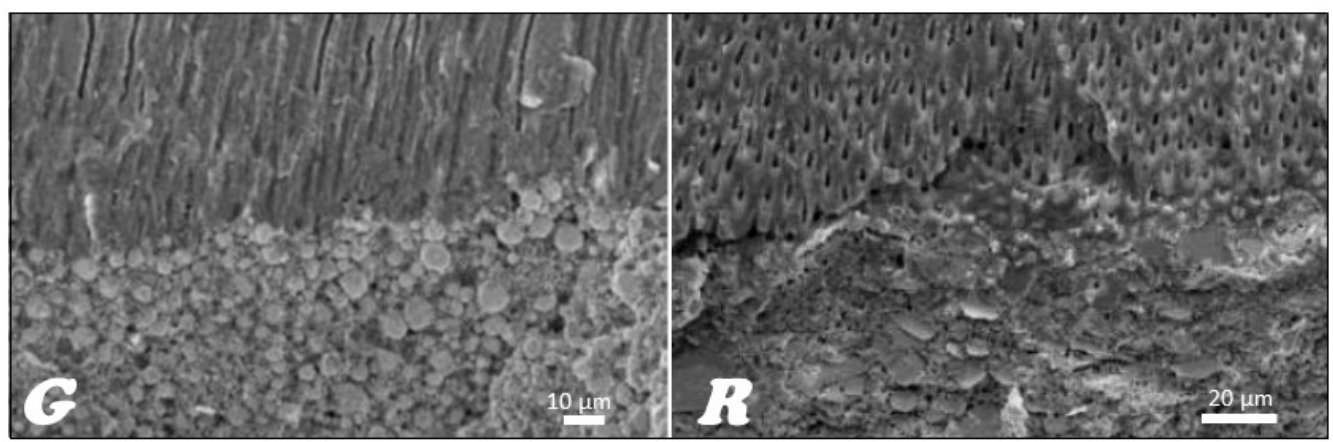

Figure 19. Tight connection as a result of cold lateral condensation of the root dentin with the filling material covered with an intermediate layer of sealant with a visible cross-section of the dentinal tubules; material based on gutta-percha with visible dental tubules along their axis transverse to the root canal (G); resilon with a visible cross-section of the tooth tubules transverse to their axis, transverse to the axis of the root canal with a thin intermediate layer of sealant (R); SEM.

The quality of the connection of the filling material with the dentin of the root canal, in fact, determines the tightness of the root canal filling and the related tightness of the filling, and in practice, the low surface density of the leaks and their small size. In both compared filling materials, despite their tight filling, there is no penetration of sealant particles into the dental tubules. Thus, cold condensation makes the three-dimensional obturation of the root canal and the penetration of filling material and sealant into depressions and niches that may appear along the entire length of the root canal impossible (Figure 20).

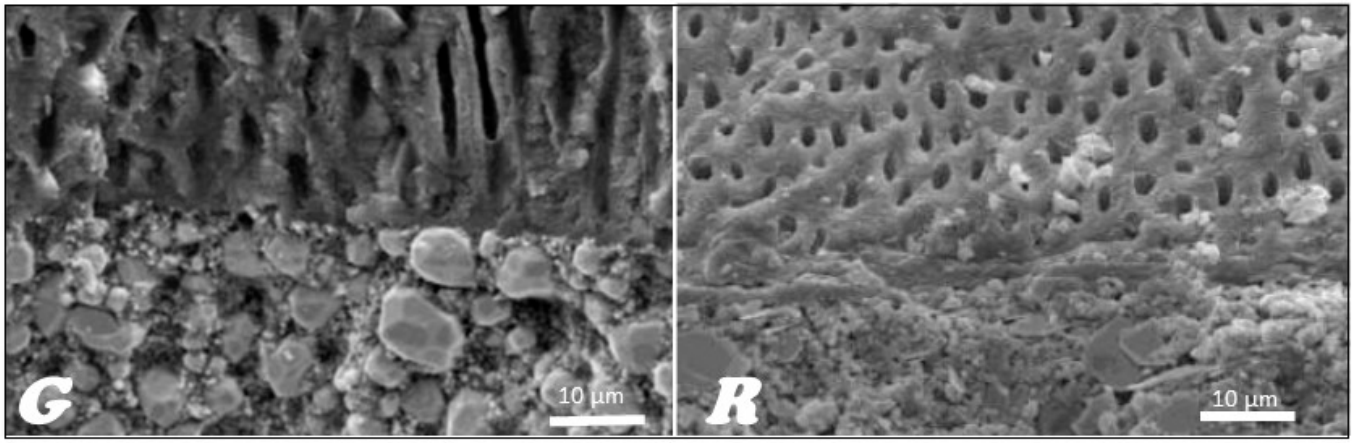

Figure 20. Connection of the dentin of the root canal with the visible dentin tubules after cold lateral condensation after filling the root canal with a material based on gutta-percha $(\mathbf{G})$ and resilon (R) covered with sealant; SEM.

Hot root canal obturation by thermoplastic condensation using the Thermo-Hydraulic Condensation (THC) technique [105-110] ensures tight and desirable adherence of the filling material, regardless of whether it is based on gutta-percha or resilon, covered with an appropriate uniform intermediate layer of root dentin sealant in each of the assessed sections of the root canal (Figure 21), which was confirmed by the results of scanning electron microscopy tests.

The tight connection of the two compared filling materials, evenly covered with the intermediate layer of the sealant, with the root canal dentin is ensured by thermoplastic application of the hot filling material using the THC technique $[96,97]$. Especially when resilon is used, the filling material is applied to the root canal by dividing it into three or four parts, between the application of which there is a vertical condensation of the material during its cooling. In this case, when joining two different parts of the filling material, correct vertical condensation occurs as the individual sections are pressed against each other by a cold piston. This minimizes the polymerization shrinkage of the filler material studs, which is particularly important when resilon is used. Obturation performed in this way prevents leaks at the boundary of the filling material covered with a thin layer of 
sealant and the root canal wall. Under these conditions, the sealant adheres closely to the root dentin in the root canal (Figure 22).
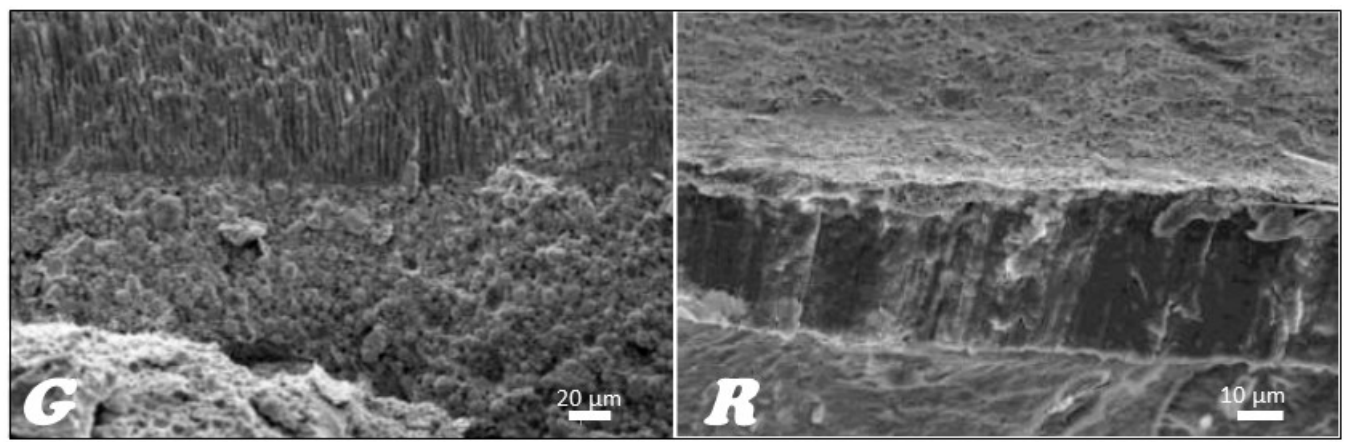

Figure 21. Tight connection of filling material covered with an intermediate layer of sealant and root canal dentin after hot thermoplastic obturation using the THC technique: (G) gutta-percha-based filling material; (R) resilon; SEM.

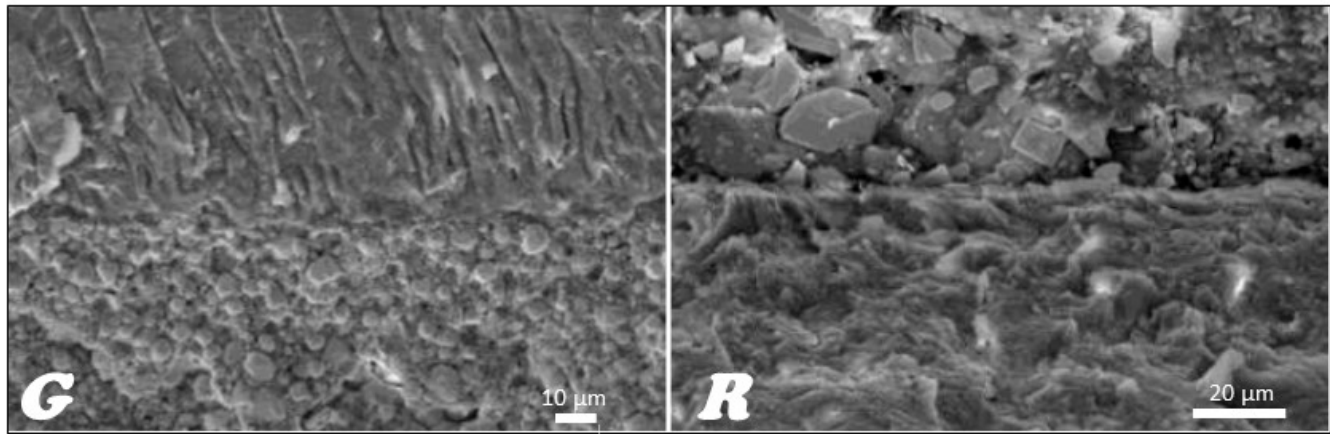

Figure 22. The borderline of the root canal wall, a thin intermediate layer of sealant and THC thermoplastically placed filling material: (G) gutta-percha-based filling material with a visible cross-section of dentinal tubules along their transverse to the axis of the root canal; $(\mathbf{R})$ resilon with visible flake structure in the sealant interlayer; SEM.

Despite the controversies presented earlier [180,181], it could be concluded that the tight connection of the sealant with the canal dentin after hot obturation with the thermoplastic THC technique, regardless of the filling material used among the two compared (Figures 23 and 24), corresponds to the concept of tertiary monoblock [187-189]. The mouths of the dental tubules are closed with sealant flakes, and the filling material adheres closely to the root canal wall $[96,97]$.
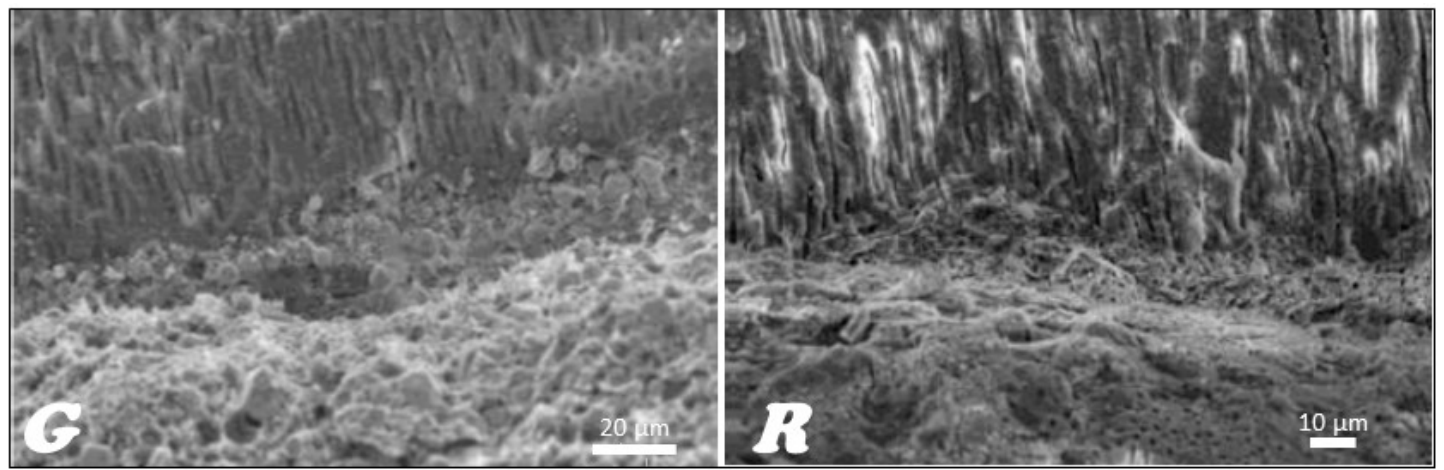

Figure 23. The structure of the connection of the root dentin with the filling material using hot thermoplastic condensation using the THC technique, covered with a thin interlayer of the sealant with its fine-flake structure and the cross-section of the tooth tubules along their axis transverse to the root canal axis after obturation with a gutta-percha-based material (G) and resilon (R); SEM. 


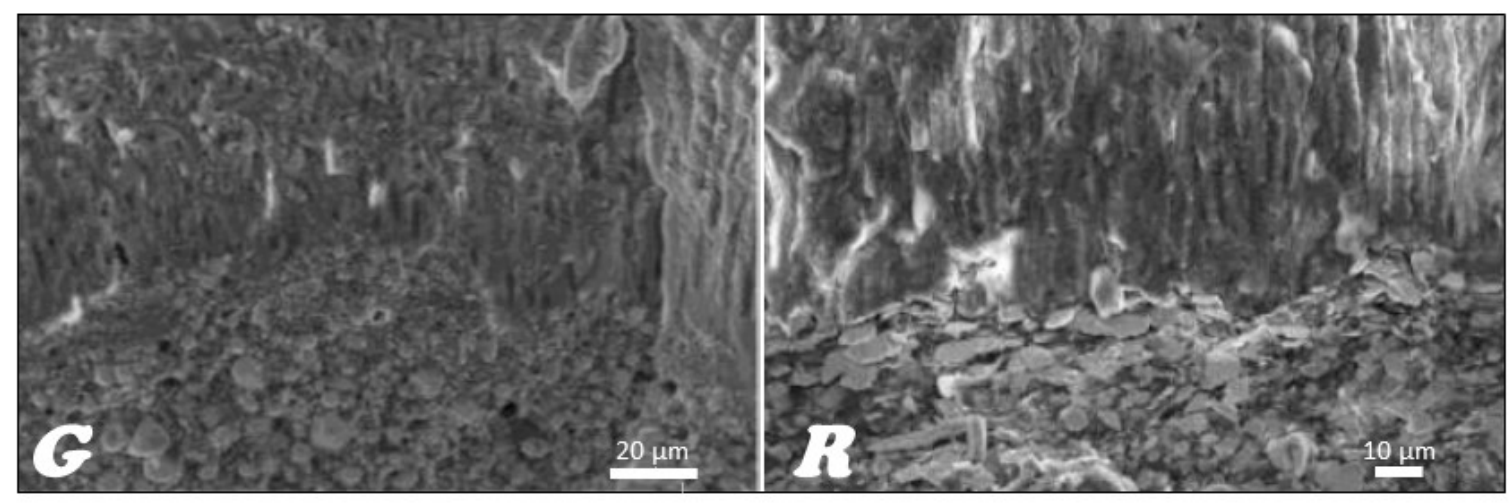

Figure 24. Tight connection of the sealant with the root canal dentin after hot obturation using the thermoplastic THC technique: (G) fine particles of the sealant in the view of the longitudinal course of the dentinal tubules on the border with a tight connection of the sealant with the root canal wall after filling with a gutta-percha-based material; (R) even distribution of the sealant on the root canal adjacent to the dentin, closing the mouths of the dentinal tubules after resilon obturation; SEM.

Using a filling material based on gutta-percha, a tight three-layer connection of the root dentin filling material takes place with the participation of a sealant interlayer, the flake structure of which allows it to close the dentinal tubules (Figure 24). The analysis of the filling of the dentinal tubules by the sealant in the apical, medial, and coronary sections shows that this penetration is statistically shallower in the apical area than in the remaining sections of the root canal.

Both methods of thermoplastic hot obturation using the THC technique applied to the filling material based on gutta-percha and resilon, and the Thermafil methods applied to the filling material based on gutta-percha, require a much lower proportion of the sealant compared to the actual filling material in the root canal, compared to the method of cold obturation on the root canal (Figure 25). There is often a tight monoblock of dentin, sealant, and main filling material, despite claims contested this concept $[190,191]$. The chance of minimizing polymerization shrinkage increases because the application of the material to the root canal is divided into three or four parts, between which there is a sealant. As a result of dividing the application of the main stud, when resilon is used, the polymerization shrinkage is also reduced, which also reduces the proportion of sealant and lack of leaks at the boundary of the filling material and the root canal wall (Figure 25). Conversely, when the Thermafil obturator is used, there is a significant build-up of sealant in the periapical area, caused by the apical movement of the sealant by the obturator pressing against the less sticky components.

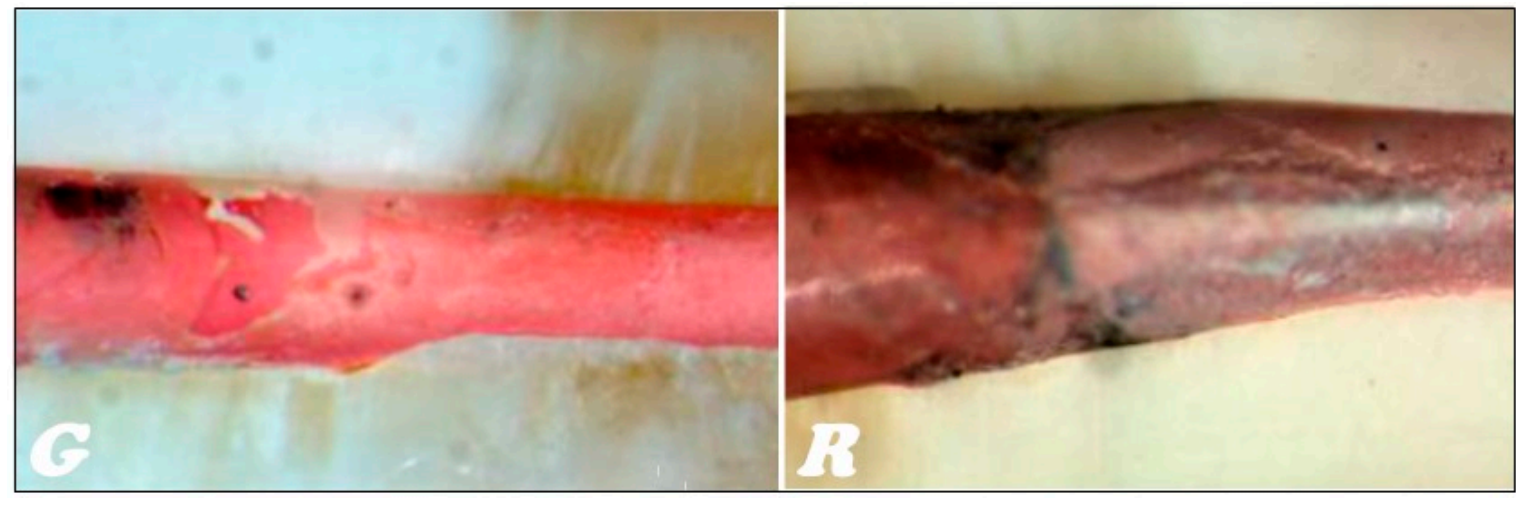

Figure 25. Longitudinal fractures of the teeth filled with hot THC technique in the middle part of the root canal (G) with gutta-percha matrix material and $(\mathbf{R})$ resilon with a visible linear connection of the main stud with the supplementary material, connected and covered with a thin layer of sealant; LSM. 
The tight connection of the sealant with the canal dentin after hot obturation with the thermoplastic THC technique is demonstrated by the AH Plus sealant based on synthetic resins, which can be used regardless of the technique of obturation with gutta-percha-based material. Due to the fine-particle structure, this sealant is characterized by the ability to penetrate deep into the dentinal tubules. As a result of THC obturation, not only the sealant but also the filling material penetrates the dentinal tubules. In this respect, the material based on gutta-percha shows slightly better properties than resilon (Figure 26).

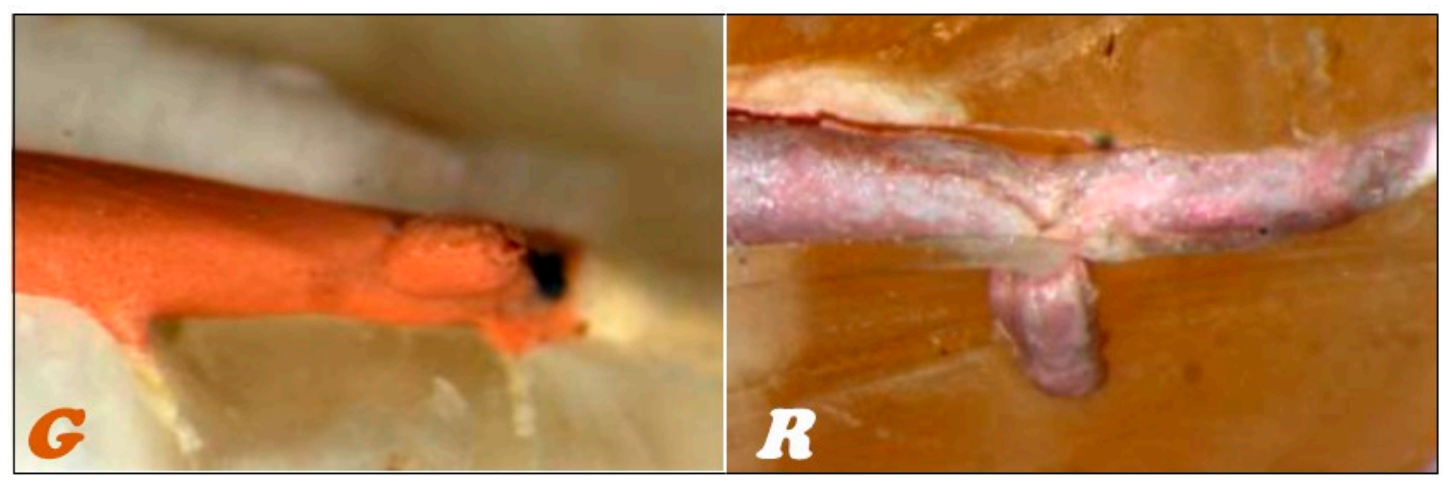

Figure 26. Lateral tubules in the apical part of the root canal filled with THC hot thermoplastic condensation (G) filled with a sealant and partially filled with material based on gutta-percha and (R) and sealant-coated resilon; LSM.

The obturation technique has a decisive impact on the possibility of providing threedimensional obturation of the root canal with filling its additional structures [86,87]. In the cold obturation method, only the sealant fills the root delta and lateral canals, while in the thermoplastic method, the root delta and lateral canals are, in turn, filled with both the sealant and the filling material, mainly when a gutta-perch-based filling material is used on the base of gutta-percha. Both thermoplastic methods, THC and Thermafil, applied to the filling material based on gutta-percha provide three-dimensional obturation of the root canal with filling its additional structures [86].

In the case of the THC thermoplastic method with the use of System B and Obtura III with gutta-percha as the filling material, the side canals, especially in the delta zone of the root canal, are filled with material based on gutta-percha concentrically in relation to the central canal, while at the same time there is a centrifugal filling with sealant in relation to the main canal (Figure 27). At the same time, the closer the root canal is to the coronary part, the more likely it will be filled with gutta-percha-based material in both thermoplastic methods [86,87]. As one approaches the apical region, the tubules are filled with sealant centrifugally to the root canal and concentrically filled with gutta-percha-based material. Directly at the apex, the side canals are filled only with sealant.

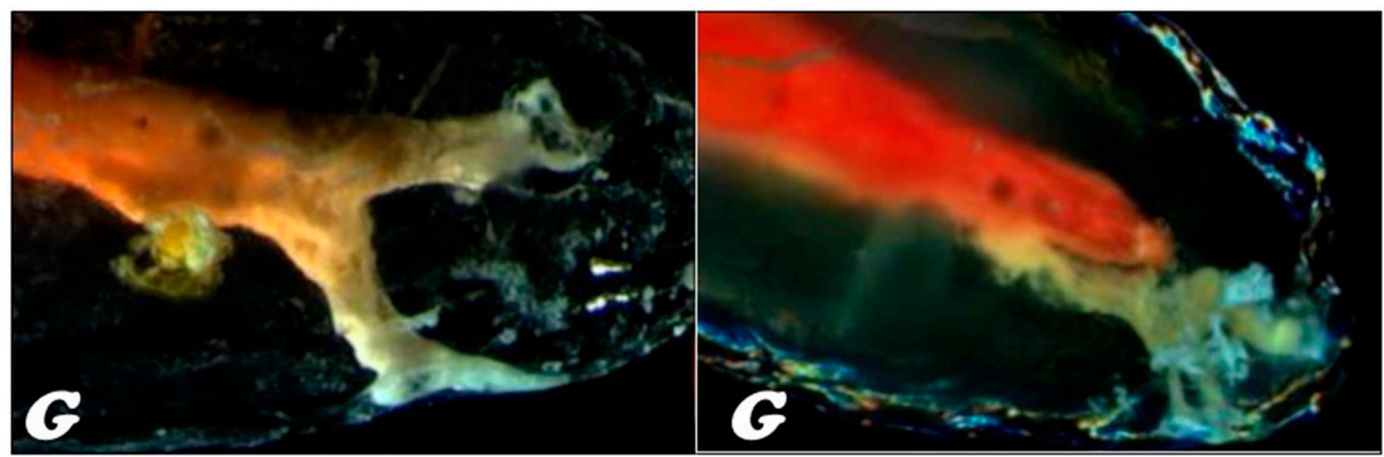

Figure 27. The structure of filling the delta zone of the root canal after obturation with the THC technique of hot thermoplastic condensation with the use of a filling material based on gutta-percha $(\mathbf{G})$ in teeth subjected to decalcification with a sealant; LSM. 
Even in the case of tight obturation of the root canal using the THC technique, both with the use of gutta-percha-based filling material and resilon, there are gaps between the root dentin and the filling material covered with a sealant (Figure 28).

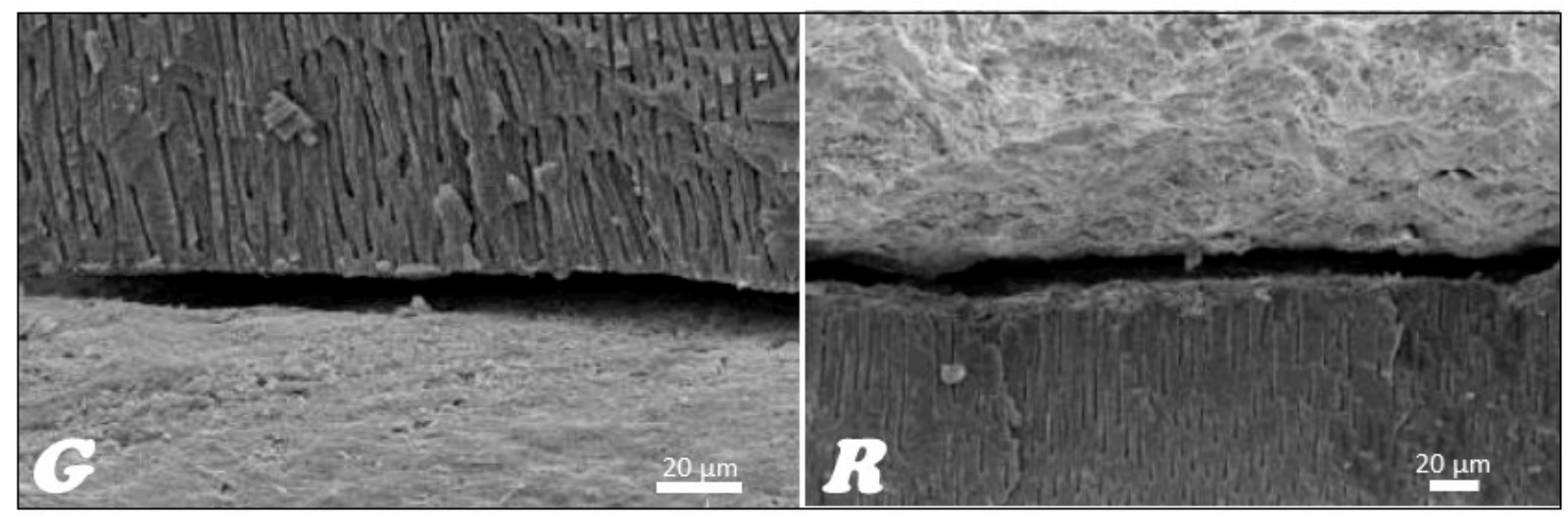

Figure 28. Picture of the leak on the border of the sealant and the dentin of the root canal filled with filling material (G) based on hot gutta-percha using the thermoplastic technique THC; (R) resilon through cold lateral condensation; SEM.

Leaks in the case of obturation using a gutta-percha-based material have a width in the range of $1.061-8.131 \mu \mathrm{m}$, while in the case of using resilon they reach $3.535-7.070 \mu \mathrm{m}$ (Figure 29). These leaks can occur on the border of the filler material where the sealant and the root dentin have not been found, as well as in the sealant layer itself, closely connected on one side to the root dentin and on the other side to the filler material.

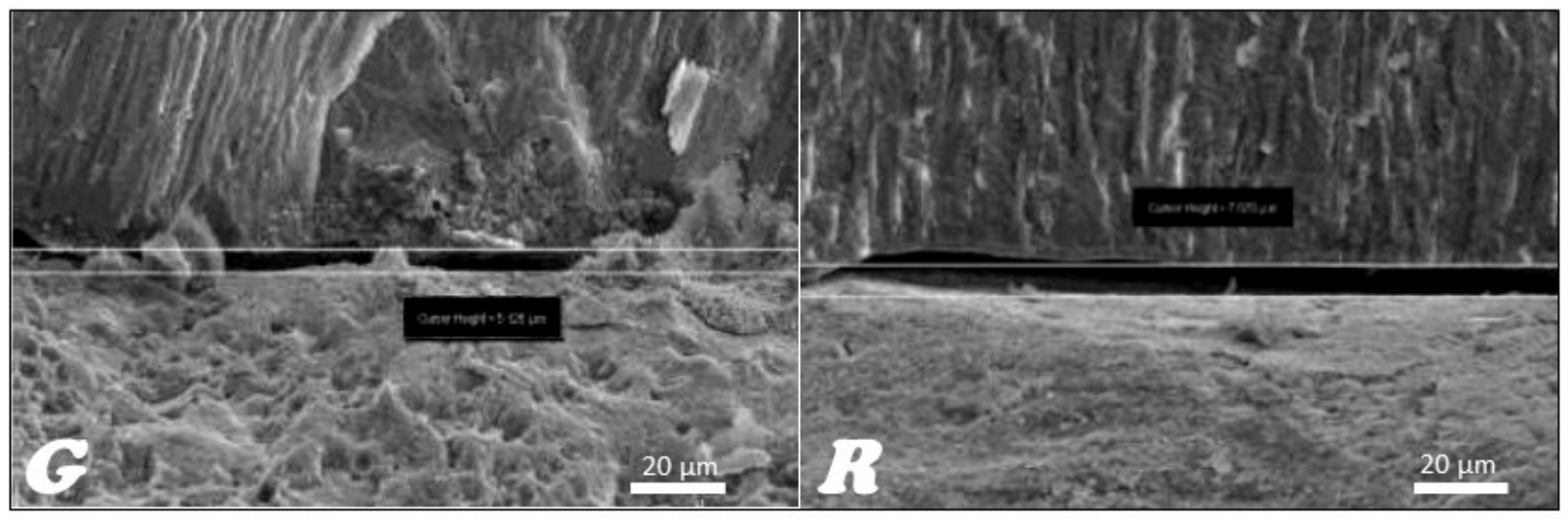

Figure 29. Examples of leakage on the border of the sealant and dentin of the root canal hot-filled with the thermoplastic technique THC $(\mathbf{G})$ with a width of $5.126 \mu \mathrm{m}$ in the case of using a material based on gutta-percha and (R) with a width of $7.070 \mu \mathrm{m}$ with the use of resilon; SEM.

The preparation and obturation of the root canal using the THC method ensure, along the entire length of the root canal, the average value of the fissure width in the case of material based on gutta-percha $4.76 \pm 0.66 \mu \mathrm{m}$ and in the case of resilon $7.86 \pm 1.19 \mu \mathrm{m}$. These values differ for individual sections of the root canal. In the case of the coronary section, the mean values of the fissure width are $5.74 \pm 0.85 \mu \mathrm{m}$ for gutta-percha and $8.70 \pm 1.56 \mu \mathrm{m}$ for resilon, respectively. The widths of the fissure in the middle section of the root canal are $4.88 \pm 1.02 \mu \mathrm{m}$ in the case of gutta-percha and $7.96 \pm 1.87 \mu \mathrm{m}$ in the case of resilon. Measurements of the apical section of the root canal indicate that the widths of the gaps are $2.33 \pm 0.87 \mu \mathrm{m}$ in the case of gutta-percha and $2.77 \pm 1.83 \mu \mathrm{m}$ in the case of resilon.

The detailed results of the measurements are presented in Figure 29. The analysis of the significance level of the differences between the widths of the fissures in all analyzed 
sections for the entire root (Figure 30) shows that in all sections along the entire length, the differences between the THC method of root canal preparation and obturation and other methods are significant. It means that in this case the best endodontic treatment results are obtained among all the analyzed techniques of preparation and obturation.

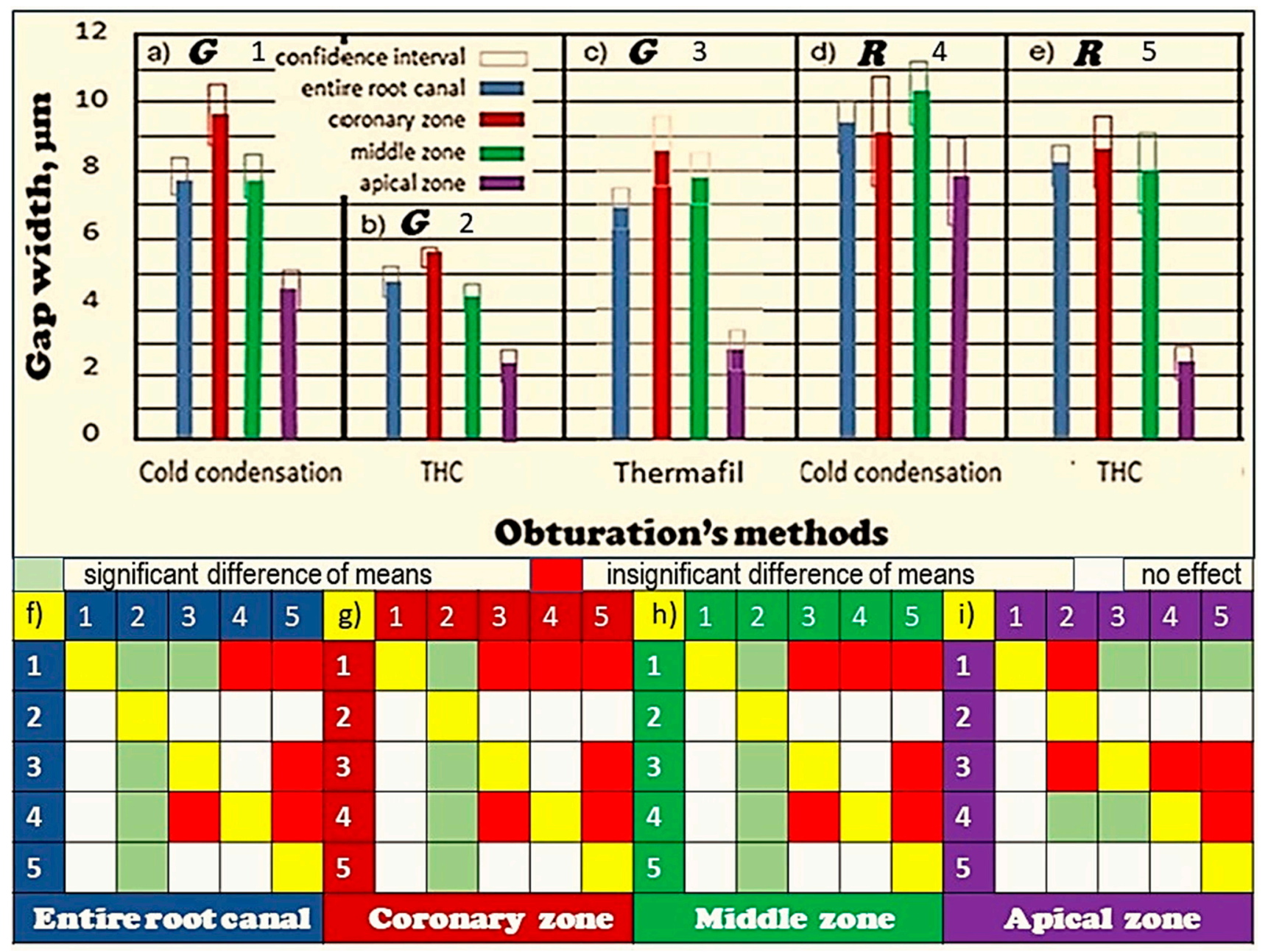

Figure 30. Generalization of the measurement results: $(\mathbf{a}-\mathbf{c})$ statistical analysis of the measurement results of the gap between the sealant and dentin of root canals filled with gutta-percha-based material $(\mathbf{a}-\mathbf{c})(1-3)$ and resilon $(\mathbf{d}, \mathbf{e})(4,5)$ after filling with the following methods: $(\mathbf{a}, \mathbf{d})$ cold; $(\mathbf{b}, \mathbf{c}, \mathbf{e})$ thermoplastic method using: (b,e) THC; (c) Thermafil; (f-i) a summary of the significance level of the differences between the average width of the gaps for the studied groups: (f) entire root canal; (g) coronary zone; (h) middle zone; (i) apical zone.

Similarly, the analysis of the significance of mean differences indicates that the width of the gaps in each case is statistically significantly different, and in each case of using resilon is greater than when using a material based on gutta-percha.

A method consisting of the preparation of root canals with K3 rotary tools (Sybron Endo), up to the size of 40 ISO using the X-Smart endodontic micromotor (DentSply/Maillefer) in two stages, and the filling of the teeth with the THC thermoplastic method using the System B and Obtura III devices (SybronEndo) with studs and pellets made of material based on gutta-percha after covering the root canal walls with a paper filter with a thin layer of AH Plus sealant (DentSply/Maillefer) shows the best results both in terms of the width of the gaps in all analyzed sections and on average for the entire root canal (Figure 30). 


\section{Description of the Results of Comparative Analyses Using the Contextual Matrix and SWOT Methods}

A comparative analysis was performed using a dendrological context matrix to compare the seven most commonly used materials for filling root canals to close them [92]. On the vertical axis of the dendrological matrix, a generalized index of material strength in the canal is placed, taking into account the strengthening of the root canal and preserving mechanical strength against fracture in combination with the tightness of the filling and its minimum resorption over time.

On the horizontal axis, there is a generalized indicator of the quality of the material in the root canal, related to, e.g., the influence of this material on the patient's body and the possibility of eliminating bacteria from the filled canal. Figure 31 shows the appropriate dendrological matrix and the criteria of mechanical strength influencing the potential root fracture and the quality of root canal filling. The results of the analysis showed that there are no filler materials that would meet all the requirements. The results of the analysis confirmed, however, that only two filling materials, i.e., gutta-percha-based material and resilon, are of real practical importance. The material based on gutta-percha achieved a high score in terms of strength and a relatively high level of filling quality, in contrast to resilon, which has a comparable strength index, but loses on the quality rating.

Based on the results of studies and analyses included, among others in the works $[92,96,97]$, the results of the SWOT point analysis (strengths, weaknesses, opportunities, threats) were used as a method of integrated determination and comparison of the strengths and weaknesses of each of these filling materials based on gutta-percha and resilon, as well as opportunities and threats, that flow for them from the environment. Each time and for each of the compared filler materials, five key internal and external SWOT factors were determined (Figure 33). These factors are of the greatest importance for the development of the analyzed filling materials, which were assigned weights reflecting their importance. The universal scale of relative states described earlier (Figure 13) was used. Based on each of the criteria factors, the compared materials were assessed by multiplying the awarded expert assessment by the weight assigned to each of the criteria. The sum of the weighted scores was obtained in this way for each group of SWOT factors for each filling material. Thanks to this, it becomes possible to choose a strategy for the individual filling materials used in endodontics to fill root canals.

The adopted evaluation criteria take into account the specificity of each of the compared filling materials, and the weights assigned to them are not identical in each of the analyzed cases; therefore, the results of the analyses cannot be compared directly and uncritically. Despite the fact that the scoring of strengths and opportunities is similar for each of the analyzed materials, there are fundamental differences in assessments for both weaknesses and threats. The matrix of possible development strategies for each material may be the only platform for comparing the development prospects of both these filling materials (Figure 32). 


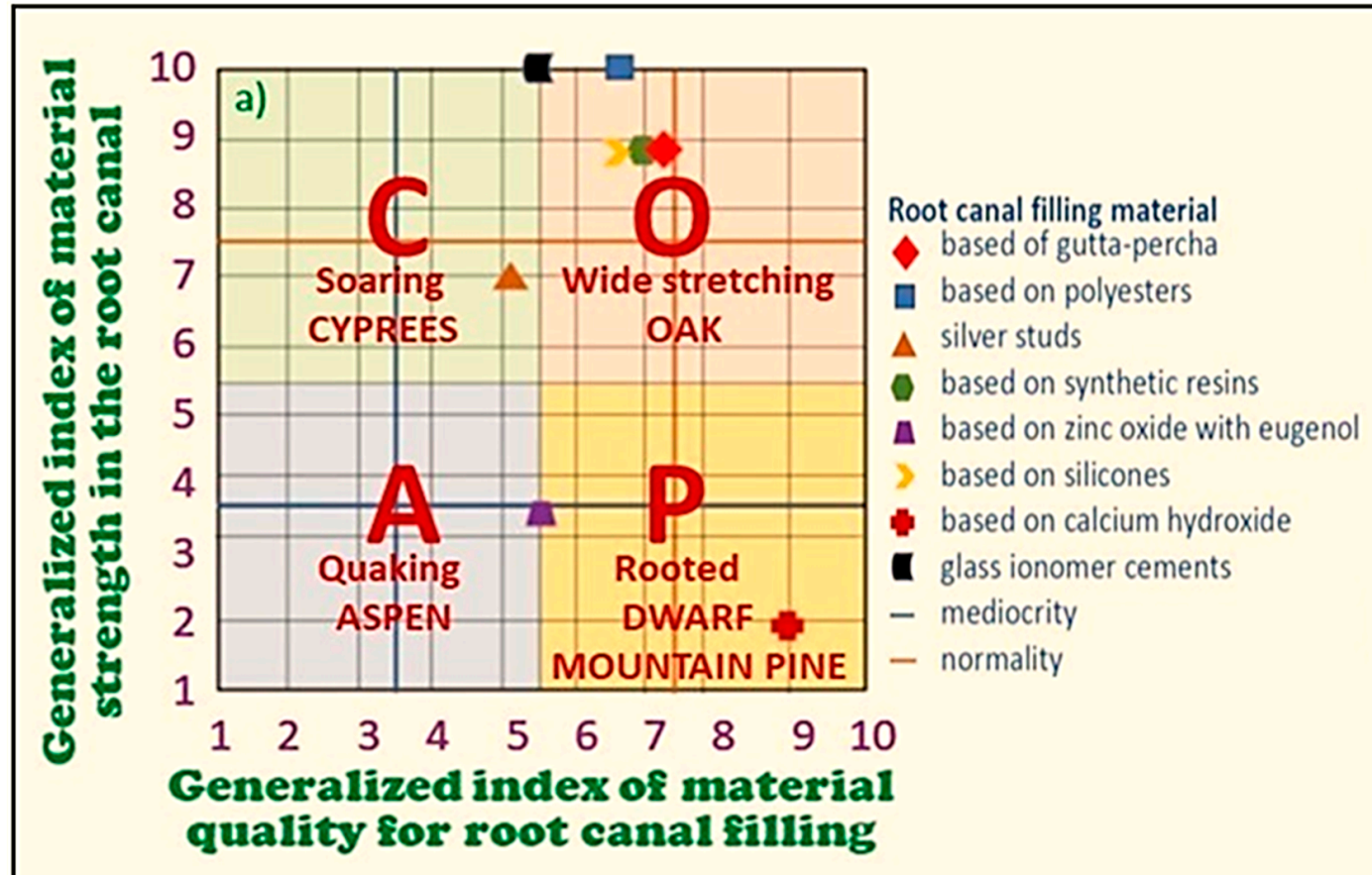

b)

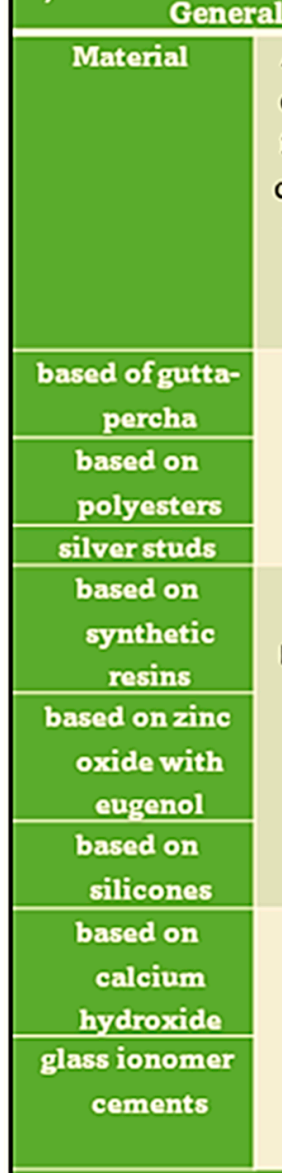

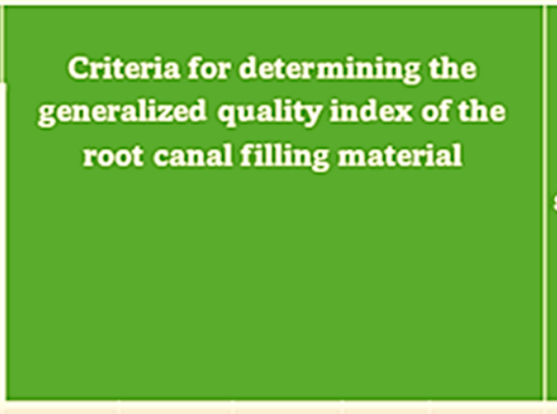

Griteria for

determining

the

generalized

strength index

of the root

canalfilling

material

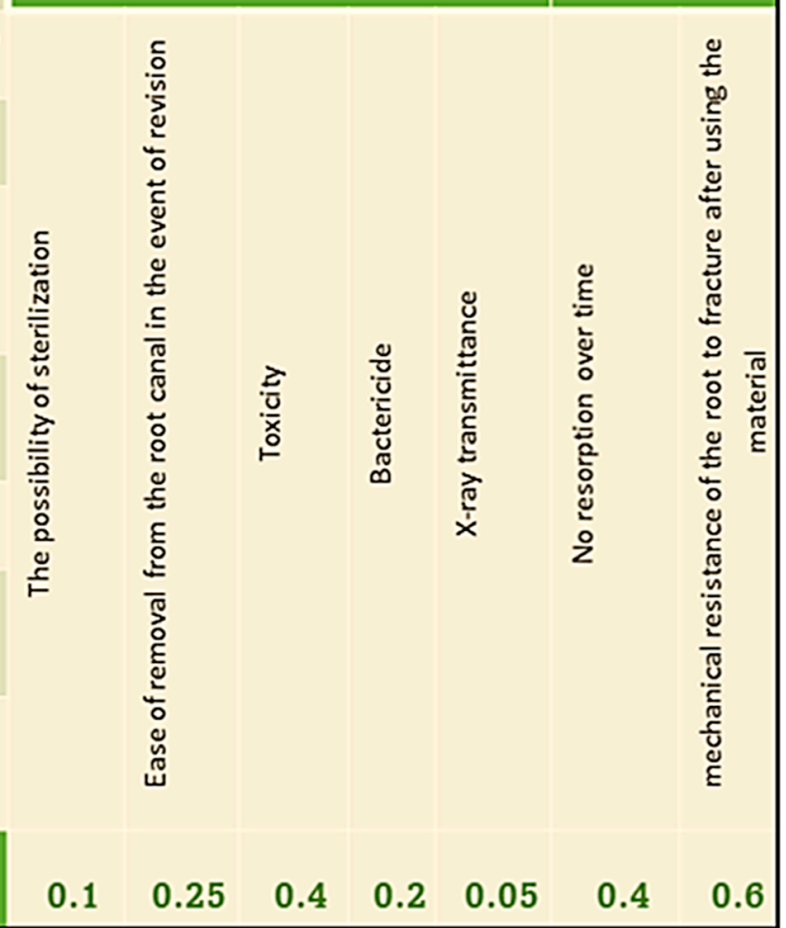

Figure 31. Contextual matrix of attractiveness (a) of virtual contextual analysis concerning the selection of root canal filling material and a set of adopted evaluation criteria $(\mathbf{b})$. 


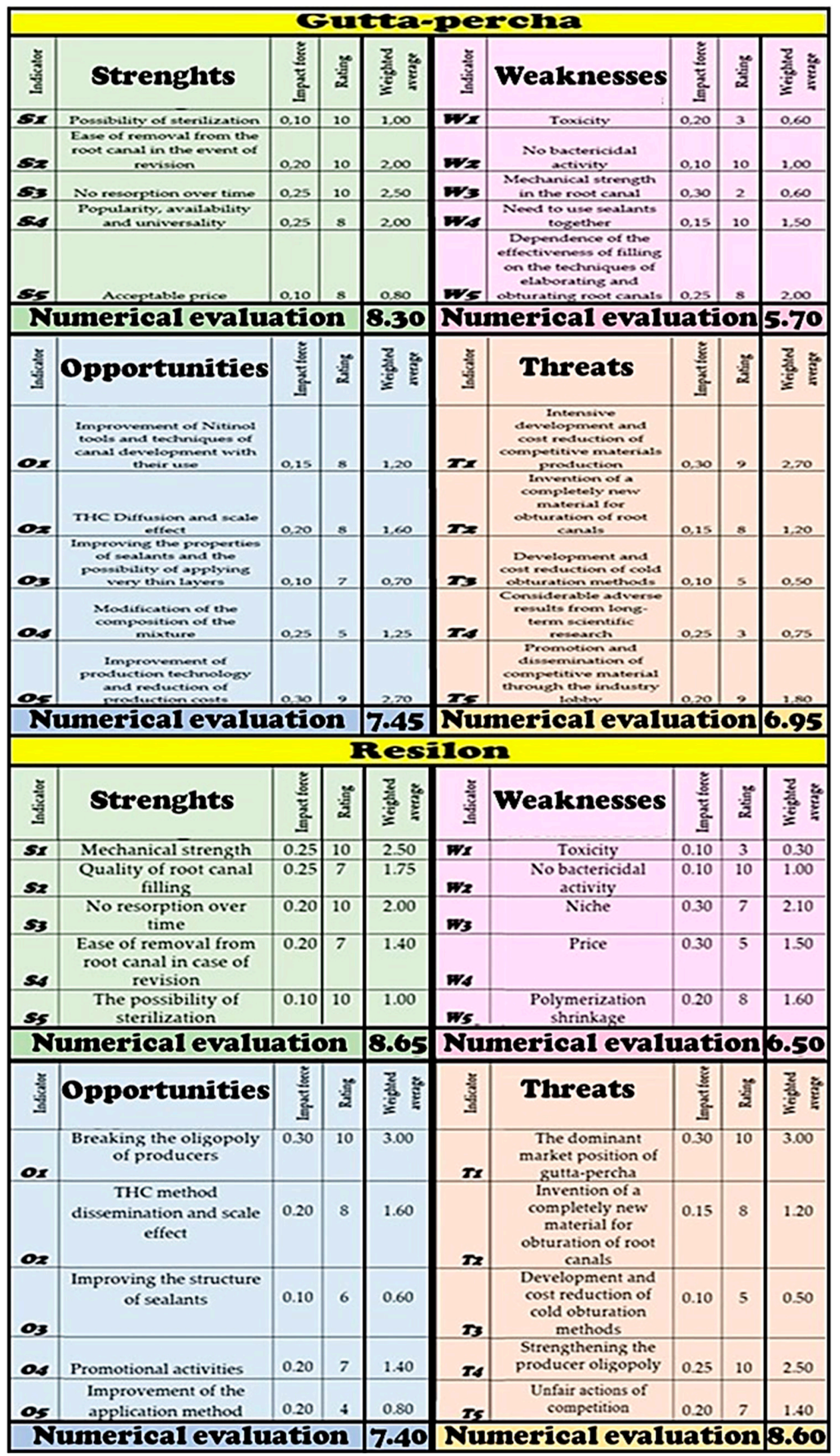

Figure 32. Criteria and results of the SWOT (strengths, weaknesses, opportunities, threats) point analysis concerning materials based on gutta-percha and resilon as materials used for filling root canals in endodontics. 
For obturation using gutta-percha-based material, a multi-criteria SWOT analysis indicates that strengths are rated as (8.30) and (8.65) for obturation with resilon. The weakness rating is (5.70) for obturation with material based on gutta-percha, while if resilon is used, the value is (6.80). In the case of using filling material based on gutta-percha, the opportunities were assessed as (7.45), while when using resilon the opportunities were (7.40). The threats of using a material based on gutta-percha are (6.95), while the environmental threats of resilon correspond to the assessment (8.60) (Figure 33).

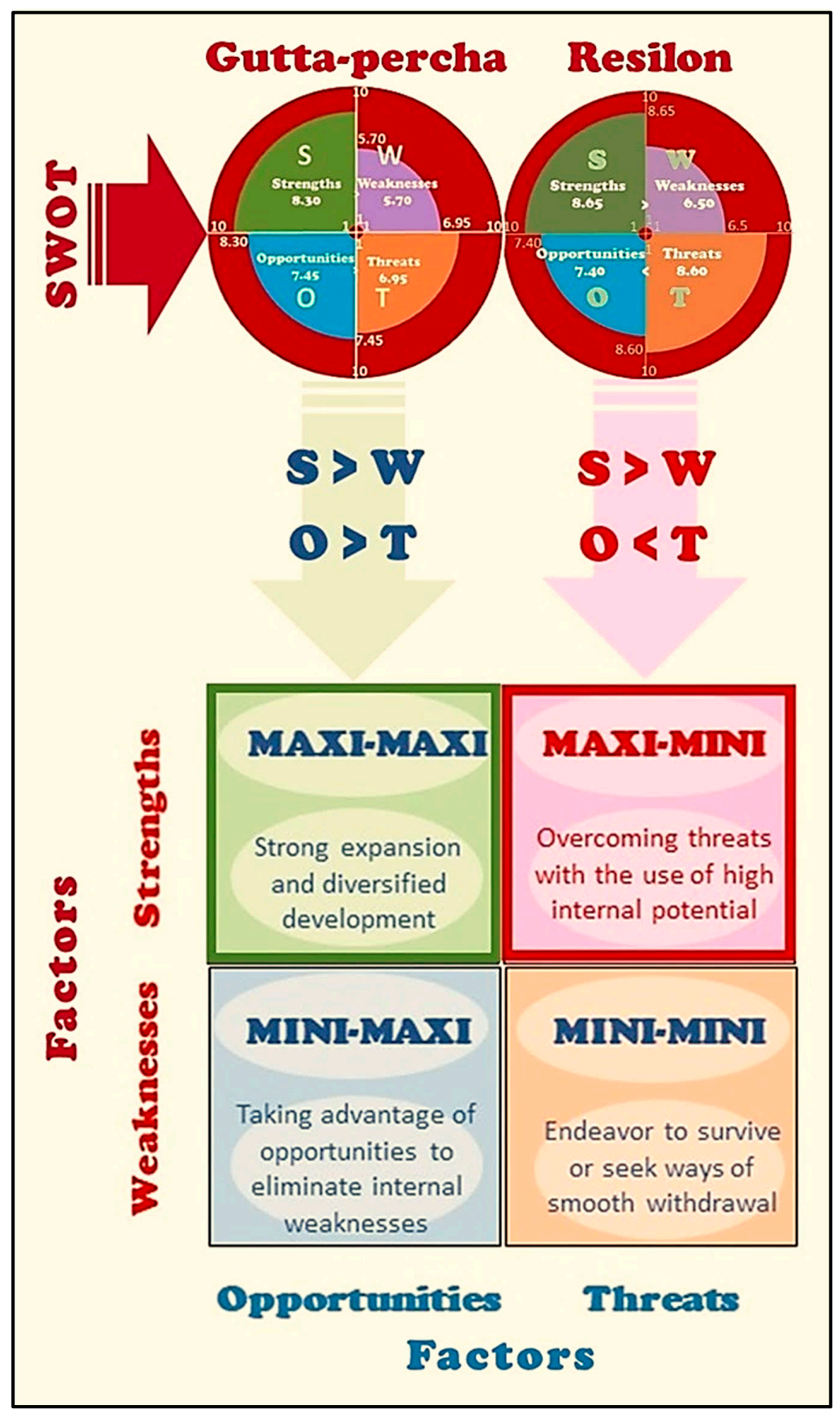

Figure 33. Results of contextual analysis SWOT (strengths-weaknesses-opportunities-threats) concerning material based on gutta-percha and resilon as the filling materials and adequate development strategies for these filling materials MAXI-MAXI and MAXI-MINI from among four possible. 
The presented data indicate that the situation of each of the analyzed materials is different from that of the other. In the case of a material based on gutta-percha, the weaknesses are significantly smaller than the strengths of this filling material $\mathrm{S}>\mathrm{W}$, and at the same time, the threats are slightly lower than the opportunities of $\mathrm{O}>\mathrm{T}$. Therefore, the predominance of positive analysis factors, both internal and external, indicates the aggressive MAXI-MAXI strategy as an adequate strategy for the development of gutta-percha-based filling material. With regard to the gutta-percha-based material, full utilization and the resulting market diversification combined with strong market expansion are required. It is highly desirable to search for new customer groups and new geographical outlets.

In the case of resilon, the strategy is quite different. Although the strengths of resilon have a significant advantage over its weaknesses $\mathrm{S}>\mathrm{W}$, the opportunities are much smaller than the threats from the environment $\mathrm{O}<\mathrm{T}$. In this case, it is only possible to apply the conservative MAXI-MINI strategy of resilon development. Such a strategy requires overcoming considerable environmental threats, with the necessary use of the considerable potential of this filling material. In such a case, a spectacular failure cannot be ruled out, and the state of threat to its development is not eliminated by the possible unexpected success.

\section{Recapitulation of the Problems}

The review of the literature contained in this paper was aimed at a comprehensive presentation of the design conditions of engineering filling materials used in endodontics as one of the typical dedicated engineering materials groups and multi-faceted analysis of the conditions of their use and the quality and durability of endodontic fillings made with their participation. This issue is important because, since caries, periodontal disease, and other oral diseases affect 3 to 5 billion people worldwide, and at least $20 \%$ of them could be qualified for endodontic treatment, the problem of appropriate material selection arises in each case. It is mainly an engineering problem, although, in the end, every dentist has to face it in relation to each patient, and in the event of a wrong decision made, it can be responsible for a serious ethical tort. It is an original approach, requiring a consistent analysis of the effect of all the component factors. For this analysis, a wide set of methods was used, not only in manufacturing engineering and materials engineering, but also in engineering and knowledge management and technology foresight. Thus, both the scope of the development of manufacturing technologies and engineering materials, taking into account the specificity of dental engineering, and the scope of oral cavity diseases and endodontics within the concept of sustainable dentistry development are presented. Endodontics, which is undoubtedly an interventionist branch of dentistry, fits into its own concept of the Sustainable Development Dentistry (DSD) $>2020$ model, consisting of Global Dental Prevention (GDP), Advanced Interventionist Dentistry 4.0 (AID 4.0), and the Dentistry Safety System (DSS). This approach is contrary to the view that there is a need to abandon interventionist treatment in favor of very comprehensive and universal prophylaxis, requiring the egalitarian reach of almost every inhabitant of the globe with dental care. The extent of caries, which covers well over $50 \%$ of the world's population, proves that interventionist treatment is an indispensable necessity.

In addition to the data from the literature on these issues, the results of experimental studies are discussed in detail to compare the appropriateness of selecting the most commonly used endodontic filling materials, respectively, based on gutta-percha or polymeric polyester materials, commonly known as resilon. The results of experimental studies with the use of stereoscopic and scanning electron microscopes as well as the results of the SWOT analysis (Strengths-Weaknesses-Opportunities-Threats) and the analysis of the dendrological matrix are presented. It has been shown that due to the possibility of obtaining a sufficiently high resolution with which the examined preparations can be observed, the methods of visualization with the use of materialographic microscopes are the most useful for assessing the effectiveness of in vitro and ex post endodontic treatment methods and techniques. The main factor determining the effectiveness of endodontic filling is the selection of the filling material and the appropriate method of obturation. The tight 
connection of the filling material is evenly covered with an intermediate layer of sealant, and the dentin of the root canal takes place only in the case of thermal obturation with the filling material using the THC method using the Obtura III and System B devices.

\section{Conclusions}

Since none of the filling materials fully meet the expectations of endodontics, the introduction of a completely new filling material would undoubtedly be a breakthrough. The challenge in the present reality, however, seems only hypothetical. The comparison of the experimental results and the analyses performed allowed for the identification of the development strategy of MAXI-MAXI concerning the filling material based on guttapercha and MAXI-MINI in the case of resilon. This indicates the decisive advantage of the gutta-percha filling material. The analysis of these experimental data does not indicate the actual competitiveness of resilon against the gutta-percha-based material, which deservedly maintains its strong position as the "gold standard of endodontics".

Author Contributions: Conceptualization, literature review, presentation, design, resources, data curation, software, formal analysis, writing, original draft preparation, visualization-J.D., L.B.D., L.A.D. and A.D.D.-D.; practical verification-J.D., L.B.D. and K.G.; writing-review and editingL.A.D., L.B.D. and A.D.D.-D.; supervision, project administration, funding acquisition-L.A.D., L.B.D. and J.D. All authors have read and agreed to the published version of the manuscript.

Funding: This research was not directly financed by external funding.

Note: The paper is prepared due to implement Project POIR.01.01-00-0485/16-00 on "IMSKA-MAT In-novative dental and maxillofacial implants manufactured using the innovative additive technology supported by computer-aided materials design ADD-MAT" realized by the Medical and Dental Engineering Center for Research, Design, and Production ASKLEPIOS in Gliwice, Poland. The project was implemented in 2017-2021 and is co-financed by the Operational Program Intelligent Development of the European Union.

Conflicts of Interest: The authors declare no conflict of interest.

\section{References}

1. UNSSC Knowledge Centre for Sustainable Development. The 2030 Agenda for Sustainable Development. Available online: https://www.unssc.org/sites/unssc.org/files/2030_agenda_for_sustainable_development_kcsd_primer_en.pdf\#: $\sim\{\}:$ text $=$ At $\% 20 \% 20$ the $\% 20 \% 20$ heart $\% 20 \% 20$ of $\% 20 \%$ 20known $\% 20 \% 20$ as $\% 20 \% 20$ the $\% 20 \% 205 \mathrm{P} \%$ E2\%80\%99s (accessed on 20 September 2021).

2. The 17 Goals. Available online: https://sdgs.un.org/goals (accessed on 1 March 2021).

3. Proposal for a Regulation of the European Parliament and of the Council on the Establishment of a Programme for the Union's Action in the Field of Health-For the Period 2021-2027 and Repealing Regulation (EU) No. 282/2014 ("EU4Health Programme"). Available online: https:/ / eur-lex.europa.eu/legal-content/EN/TXT/?uri=CELEX:52020PC0405 (accessed on 1 March 2021).

4. EU Health Policy. Available online: https://ec.europa.eu/health/policies/overview_pl (accessed on 1 March 2021).

5. Dobrzański, L.A. Materiały Inżynierskie i Projektowanie Materiałowe: Podstawy Nauki o Materiałach i Metaloznawstwo, 2nd ed.; WNT: Warsaw, Poland, 2006.

6. Dobrzański, L.A. Significance of materials science for the future development of societies. J. Mater. Proc. Tech. 2006, 175, 133-148. [CrossRef]

7. Dobrzański, L.A. Metale i ich stopy. In Open Access Library; International OCSCO World Press: Gliwice, Poland, 2017; Volume VII, pp. 1-982.

8. Dobrzański, L.A.; Dobrzańska-Danikiewicz, A.D. Inżynieria powierzchni materiałów: Kompendium wiedzy i podręcznik akademicki. In Open Access Library; International OCSCO World Press: Gliwice, Poland, 2018; Volume VIII, pp. 1-1138.

9. Dobrzański, L.A.; Dobrzański, L.B. Approach to the Design and Manufacturing of Prosthetic Dental Restorations According to the Rules of Industry 4.0. Mater. Perform. Charact. 2020, 9, 394-476. [CrossRef]

10. Dobrzański, L.A.; Dobrzańska-Danikiewicz, A.D.; Dobrzański, L.B. Effect of Biomedical Materials in the Implementation of a Long and Healthy Life Policy. Processes 2021, 9, 865. [CrossRef]

11. Pitts, N.B.; Zero, D.T. White Paper on Dental Caries Prevention and Management; FDI World Dental Federation: Geneva, Switzerland, 2016. Available online: https://www.fdiworlddental.org/resource/white-paper-dental-caries-prevention-and-management (accessed on 23 July 2021).

12. Yadav, K.; Prakash, S. Dental caries: A microbiological approach. J. Clin. Infect. Dis. Pract. 2017, 2, 1000118. [CrossRef] 
13. Psoter, W.J.; Reid, B.C.; Katz, R.V. Malnutrition and dental caries: A review of the literature. Caries Res. 2005, 39, 441-447. [CrossRef] [PubMed]

14. Twetman, S.; Banerjee, A. Caries risk assessment. In Risk Assessment in Oral Health; Chapple, I., Papapanou, P., Eds.; Springer: Cham, Switzerland, 2020. [CrossRef]

15. Fejerskov, O. Changing paradigms in concepts on dental caries: Consequences for oral health care. Caries Res. 2004, 38, 182-191. [CrossRef] [PubMed]

16. Mejàre, I.; Axelsson, S.; Dahlén, G.; Espelid, I.; Norlund, A.; Tranæus, S.; Twetman, S. Caries risk assessment. A systematic review. Acta Odontol. Scand. 2014, 72, 81-91. [CrossRef] [PubMed]

17. Selwitz, R.H.; Ismail, A.I.; Pitts, N.B. Dental caries. Lancet 2007, 369, 51-59. [CrossRef]

18. Pitts, N.B.; Zero, D.T.; Marsh, P.D.; Ekstrand, K.; Weintraub, J.A.; Ramos-Gomez, F.; Tagami, J.; Twetman, S.; Tsakos, G.; Ismail, A Dental caries. Nat. Rev. Dis. Prim. 2017, 3, 17030. [CrossRef] [PubMed]

19. Zero, D.T.; Zandona, A.F.; Vail, M.M.; Spolnik, K.J. Dental caries and pulpal disease. Dent. Clin. N. Am. 2011, 55, 29-46. [CrossRef]

20. Fejerskov, O. Concepts of dental caries and their consequences for understanding the disease. Community Dent. Oral. Epidemiol. 1997, 25, 5-12. [CrossRef] [PubMed]

21. Van Houte, J. Role of micro-organisms in caries etiology. J. Dent. Res. 1994, 73, 672-681. [CrossRef] [PubMed]

22. Pitts, N. "ICDAS" - An international system for caries detection and assessment being developed to facilitate caries epidemiology, research and appropriate clinical management. Community Dent. Health 2004, 21, 193-198. [PubMed]

23. Bolin, A.K.; Bolin, A.; Jansson, L.; Calltorp, J. Children's dental health in Europe. Swed. Dent. J. 1997, $21,25-40$.

24. Zero, D.T. Dental caries process. Dent. Clin. N. Am. 1999, 43, 635-664.

25. Kassebaum, N.J.; Bernabé, E.; Dahiya, M.; Bhandari, B.; Murray, C.J.; Marcenes, W. Global burden of untreated caries: A systematic review and metaregression. J. Dent. Res. 2015, 94, 650-658. [CrossRef]

26. Thomson, W.M. Epidemiology of oral health conditions in older people. Gerodontology 2014, 31 (Suppl. S1), 9-16. [CrossRef]

27. Biguzzi, E.; Dougall, A.; Romero-Lux, O. Non-gynaecological issues in women with bleeding disorders. J. Haemophil. Pract. 2019, 6, 39-43. [CrossRef]

28. López, N.J.; Smith, P.C.; Gutierrez, J. Periodontal therapy reduce the risk of preterm low birth weight in women with periodontal disease: A randomized controlled trial. J. Periodontol. 2002, 73, 911-924. [CrossRef]

29. Albandar, J.M.; Tinoco, E.M. Global epidemiology of periodontal diseases in children and young persons. Periodontol. 2000 2002, 29, 153-176. [CrossRef]

30. Al-Nawas, B.; Maeurer, M. Severe versus local odontogenic bacterial infections: Comparison of microbial isolates. Eur. Surg. Res. 2008, 40, 220-224. [CrossRef] [PubMed]

31. Sheiham, A.; Netuveli, G.S. Periodontal diseases in Europe. Periodontol. 2000 2002, 29, 104-121. [CrossRef] [PubMed]

32. Chapple, I.L.C.; Genco, R.; Working Group 2 of the Joint EFP/AAP Workshop. Diabetes and periodontal diseases: Consensus report of the Joint EFP/AAP Workshop on Periodontitis and Systemic Diseases. J. Periodontol. 2013, 84, S106-S112. [CrossRef] [PubMed]

33. Albandar, J.M.; Rams, T.E. Global epidemiology of periodontal diseases: An overview. Periodontol. 2000 2002, 29, 7-10. [CrossRef] [PubMed]

34. Fuller, E.; Steele, J.; Watt, R.; Nuttal, N. 1: Oral Health and Function-A Report from the Adult Dental Health Survey 2009; NHS Health and Social Care Information Centre: London, UK, 2011. Available online: https://files.digital.nhs.uk/publicationimport/pub0 1xxx/pub01086/adul-dent-heal-surv-summ-them-the1-2009-rep3.pdf (accessed on 23 July 2021).

35. Papapanou, P.N. Commentary: Advances in periodontal disease epidemiology: A retrospective commentary. J. Periodontol. 2014, 85, 877-879. [CrossRef] [PubMed]

36. Dobrzański, L.A.; Dobrzański, L.B.; Dobrzańska-Danikiewicz, A.D.; Dobrzańska, J. The Concept of Sustainable Development of Modern Dentistry. Processes 2020, 8, 1605. [CrossRef]

37. Watt, R.G.; Daly, B.; Allison, P.; Macpherson, L.M.D.; Venturelli, R.; Listl, S.; Weyant, R.J.; Mathur, M.R.; Guarnizo-Herreño, C.C.; Celeste, R.K. Ending the neglect of global oral health: Time for radical action. Lancet 2019, 394, 261-272. [CrossRef]

38. Peres, M.A.; Macpherson, L.M.D.; Weyant, R.J.; Daly, B.; Venturelli, R.; Mathur, M.R.; Listl, S.; Celeste, R.K.; Guarnizo-Herreño, C.C.; Kearns, C. Oral diseases: A global public health challenge. Lancet 2019, 394, 249-260. [CrossRef]

39. Featherstone, J.D. The continuum of dental caries-Evidence for a dynamic disease process. J. Dent. Res. 2004, 83, C39-C42. [CrossRef]

40. Pitts, N.B. A review of the current knowledge of the progress of approximal lesions. In Proceedings of the Scientific Proceedings of the 10th Asian Pacific Dental Congress, Singapore, 26-31 March 1981; Singapore Dental Association: Singapore, 1983; pp. 31-36.

41. Reisine, S.; Litt, M. Social and psychological theories and their use for dental practice. Int. Dent. J. 1993, 43 (Suppl. S1), $279-287$.

42. Takahashi, N.; Nyvad, B. Caries ecology revisited: Microbial dynamics and the caries process. Caries Res. 2008, 42, 409-418. [CrossRef]

43. Marsh, P.D. Microbial ecology of dental plaque and its significance in health and disease. Adv. Dent. Res. 1994, 8, $263-271$. [CrossRef] [PubMed]

44. Zero, D.T. Adaptations in dental plaque. In Cariology for the Nineties; Bowen, W.H., Tabak, L., Eds.; University of Rochester Press: Rochester, NY, USA, 1993; pp. 333-350. 
45. Aas, J.A.; Griffen, A.L.; Dardis, S.R.; Lee, A.M.; Olsen, I.; Dewhirst, F.E.; Leys, E.J.; Paster, B.J. Bacteria of dental caries in primary and permanent teeth in children and young adults. J. Clin. Microbiol. 2008, 46, 1407-1417. [CrossRef] [PubMed]

46. Kleinberg, I. A mixed-bacteria ecological approach to understanding the role of the oral bacteria in dental caries causation: An alternative to Streptococcus mutans and the specific-plaque hypothesis. Crit. Rev. Oral Biol. Med. 2002, 13, 108-125. [CrossRef] [PubMed]

47. Arif, N.; Sheehy, E.C.; Do, T.; Beighton, D. Diversity of Veillonella spp. from sound and carious sites in children. J. Dent. Res. 2008, 87, 278-282. [CrossRef]

48. Sheiham, A.; James, W.P.T. Diet and Dental Caries: The Pivotal Role of Free Sugars Reemphasized. J. Dent. Res. 2015, 94, 1341-1347. [CrossRef]

49. Moynihan, P.J.; Kelly, S.A. Effect on caries of restricting sugars intake: Systematic review to inform WHO guidelines. J. Dent. Res. 2014, 93, 8-18. [CrossRef]

50. Sheiham, A.; James, W.P. A reappraisal of the quantitative relationship between sugar intake and dental caries: The need for new criteria for developing goals for sugar intake. BMC Public Health 2014, 14, 863. [CrossRef]

51. Liu, Y.-L.; Nascimento, M.; Burne, R.A. Progress toward understanding the contribution of alkali generation in dental biofilms to inhibition of dental caries. Int. J. Oral Sci. 2012, 4, 135-140. [CrossRef]

52. Zero, D.T. Sugars-The arch criminal? Caries Res. 2004, 38, 277-285. [CrossRef]

53. Walsh, T.; Worthington, H.V.; Glenny, A.M.; Appelbe, P.; Marinho, V.C.; Shi, X. Fluoride toothpastes of different concentrations for preventing dental caries in children and adolescents. Cochrane Database Syst. Rev. 2010, 1, CD007868, Update in Cochrane Database Syst. Rev. 2019, 3, CD007868. [CrossRef]

54. Marinho, V.C.; Higgins, J.P.; Logan, S.; Sheiham, A. Topical fluoride (toothpastes, mouthrinses, gels or varnishes) for preventing dental caries in children and adolescents. Cochrane Database Syst. Rev. 2003, 4, CD002782. [CrossRef] [PubMed]

55. Pollick, H.F. Salt fluoridation: A review. J. Calif. Dent. Assoc. 2013, 41, 395-404. [PubMed]

56. Zero, D.T. The role of dietary control. In Dental Caries: The Disease and its Clinical Management, 2nd ed.; Fejerskov, O., Kidd, E., Eds.; Blackwell Munksgaard: Oxford, UK, 2008; pp. 329-352.

57. Holmgren, C.; Gaucher, N.; Decerle, N.; Doméjean, S. Minimal intervention dentistry II: Part 3. Management of non-cavitated (initial) occlusal caries lesions-Non-invasive approaches through remineralization and therapeutic sealants. Br. Dent. J. 2014, 216, 237-243. [CrossRef] [PubMed]

58. Zero, D.T. Dentifrices, mouthwashes, and remineralization/caries arrestment strategies. BMC Oral Health 2006, 6, S9. [CrossRef]

59. Amaechi, B.T. Remineralization therapies for initial caries lesions. Curr. Oral Health Rep. 2015, 2, 95-101. [CrossRef]

60. Margolis, H.C.; Moreno, E.C. Composition and cariogenic potential of dental plaque fluid. Crit. Rev. Oral Biol. Med. 1994, 5, 1-25. [CrossRef]

61. Kidd, E.A.M.; Fejerskov, O. What constitutes dental caries? Histopathology of carious enamel and dentin related to the action of cariogenic biofilms. J. Dent. Res. 2004, 83, C35-C38. [CrossRef]

62. Reynolds, E.C.; Cai, F.; Shen, P.; Walker, G.D. Retention in plaque and remineralization of enamel lesions by various forms of calcium in a mouthrinse or sugar-free chewing gum. J. Dent. Res. 2003, 82, 206-211. [CrossRef]

63. Kitasako, Y.; Sadr, A.; Hamba, H.; Ikeda, M.; Tagami, J. Gum containing calcium fluoride reinforces enamel subsurface lesions in situ. J. Dent. Res. 2012, 91, 370-375. [CrossRef]

64. Hamba, H.; Nikaido, T.; Inoue, G.; Sadr, A.; Tagami, J. Effects of CPP-ACP with sodium fluoride on inhibition of bovine enamel demineralization: A quantitative assessment using micro-computed tomography. J. Dent. 2011, 39, 405-413. [CrossRef] [PubMed]

65. Amaechi, B.T.; van Loveren, C. Fluorides and non-fluoride remineralization systems. Monogr. Oral Sci. 2013, 23, 15-26. [CrossRef] [PubMed]

66. Lee, Y.E.; Baek, H.J.; Choi, Y.H.; Jeong, S.H.; Park, Y.D.; Song, K.B. Comparison of remineralization effect of three topical fluoride regimens on enamel initial carious lesions. J. Dent. 2010, 38, 166-171. [CrossRef]

67. Iheozor-Ejiofor, Z.; Worthington, H.V.; Walsh, T.; O’Malley, L.; Clarkson, J.E.; Macey, R.; Alam, R.; Tugwell, P.; Welch, V.; Glenny, A.M. Water fluoridation for the prevention of dental caries. Cochrane Database Syst. Rev. 2015, 2015, CD010856. [CrossRef] [PubMed]

68. Ten Cate, J.M.; Featherstone, J.D. Mechanistic aspects of the interactions between fluoride and dental enamel. Crit. Rev. Oral Biol. Med. 1991, 2, 283-296. [CrossRef] [PubMed]

69. Featherstone, J.D. Prevention and reversal of dental caries: Role of low level fluoride. Community Dent. Oral Epidemiol. 1999, 27, 31-40. [CrossRef] [PubMed]

70. Tan, H.; Peres, K.G.; Peres, M.A. Retention of Teeth and Oral Health-Related Quality of Life. J. Dent. Res. 2016, 95, 1350-1357. [CrossRef]

71. Dobrzański, L.A.; Dobrzański, L.B.; Dobrzańska-Danikiewicz, A.D.; Dobrzańska, J.; Rudziarczyk, K.; Achtelik-Franczak, A. Non-antagonistic contradictoriness of the progress of advanced digitized production with SARS-CoV-2 virus transmission in the area of dental engineering. Processes 2020, 8, 1097. [CrossRef]

72. Aleksander, M.; Krishnan, B.; Shenoy, N. Diabetes mellitus and odontogenic infections-an exaggerated risk? Oral Maxillofac. Surg. 2008, 12, 129-130. [CrossRef]

73. Scannapieco, F.A.; Bush, R.B.; Paju, S. Associations between periodontal disease and risk for nosocomial bacterial pneumonia and chronic obstructive pulmonary disease, A systemic review. Ann. Periodontol. 2003, 8, 54-69. [CrossRef] 
74. Li, X.; Tornstad, L.; Olsen, I. Brain abscesses caused by oral infection. Dent. Traumatol. 1999, 15, 95-101. [CrossRef] [PubMed]

75. Scannapieco, F.A. Role of oral bacteria in respiratory infection. J. Periodontol. 1999, 70, 793-802. [CrossRef] [PubMed]

76. Mueller, A.A.; Saldami, B.; Stübinger, S.; Walter, C.; Flückiger, U.; Merlo, A.; Schwenzer-Zimmerer, K.; Zeilhofer, H.F.; Zimmerer, S. Oral bacterial cultures in nontraumatic brain abscesses: Results of a first line study. Oral Surg. Oral Med. Oral Pathol. Oral Radiol. Endod. 2009, 107, 469-476. [CrossRef] [PubMed]

77. Edwards Deming, W. Out of the Crisis; Massachusetts Institute of Technology, Center for Advanced Engineering Study: Cambridge, MA, USA, 1986.

78. Dirks, O.B.; van Amerongen, J.; Winkler, K.C. A reproducible method for caries evaluation. J. Dent. Res. 1951, 30, 346-359. [CrossRef] [PubMed]

79. Marthaler, T.M. A standardized system of recording dental conditions. Helv. Odontol. Acta 1966, 10, 1-18.

80. Ismail, A.I.; Sohn, W.; Tellez, M.; Amaya, A.; Sen, A.; Hasson, H.; Pitts, N.B. The international caries detection and assessment system (ICDAS): An integrated system for measuring dental caries. Community Dent. Oral Epidemiol. 2007, 35, 170-178. [CrossRef] [PubMed]

81. ICDAS Website. Available online: https:/ / www.icdas.org/ (accessed on 23 July 2021).

82. Pitts, N.B. How the detection, assessment, diagnosis and monitoring of caries integrate with personalized caries management. Monogr. Oral Sci. 2009, 21, 1-14. [CrossRef]

83. Pitts, N.; Melo, P.; Martignon, S.; Ekstrand, K.; Ismail, A. Caries risk assessment, diagnosis and synthesis in the context of a European core curriculum in cariology. Eur. J. Dent. Educ. 2011, 15 (Suppl. S1), 23-31. [CrossRef]

84. Pitts, N.B. Modern concepts of caries measurement. J. Dent. Res. 2004, 83, 43-47. [CrossRef]

85. Alwadani, M.; Mashyakhy, M.H.; Jali, A.; Hakami, A.O.; Areshi, A.; Daghriri, A.A.; Shaabi, F.I.; Al Moaleem, M.M. Dentists and Dental Intern's Preferences of Root Canal Treatment with Restoration Versus Extraction then Implant-Supported Crown Treatment Plan. Open Dent. J. 2019, 13, 93-100. [CrossRef]

86. Estrela, C.; Holland, R.; Estrela, C.R.; Alencar, A.H.; Sousa-Neto, M.D.; Pécora, J.D. Characterization of successful root canal treatment. Braz. Dent. J. 2014, 25, 3-11. [CrossRef] [PubMed]

87. Wang, Z.; Pan, J.; Wright, J.T.; Bencharit, S.; Zhang, S.; Everett, E.T.; Teixeira, F.B.; Preisser, J.S. Putative stem cells in human dental pulp with irreversible pulpitis: An exploratory study. J. Endod. 2010, 36, 820-825. [CrossRef] [PubMed]

88. Krupiński, J. Endodoncja Praktyczna; Wyd. Kwintesencja: Warszawa, Poland, 2008; pp. 30-44.

89. Dental Consumables Market by Product [Dental Implants (Root Form Dental Implants and Plate Form Dental Implants), Dental Prosthetics (Crowns, Bridges, Dentures, Abutments, Veneers, and Inlays \& Onlays), Endodontics (Endodontic Files, Obturators, and Permanent Endodontic Sealers), Orthodontics (Brackets, Archwires, Anchorage Appliances, and Ligatures), Periodontics (Dental Sutures and Dental Hemostats), Retail Dental Care Essentials (Specialized Dental Pastes, Dental Brushes, Dental Wash Solutions, Whitening Agents, and Dental Floss), and Other Dental Consumables (Dental Splints, Dental Sealants, Dental Burs, Dental Impression Materials, Dental Disposables, Bonding Agents, Patient Bibs, and Aspirator Tubes \& Saliva Ejectors)]—Global Opportunity Analysis and Industry Forecast, 2017-2023. Available online: https://www.alliedmarketresearch.com/dentalconsumables-market (accessed on 23 July 2021).

90. Endodontic Devices Market Size, Share \& Trends Analysis Report by Type (Instruments, Consumables), by End Use (Hospitals, Clinics, Dental Academic \& Research Institutes), and Segment Forecasts, 2019-2026. Available online: https://www. grandviewresearch.com/industry-analysis/endodontic-devices-market (accessed on 23 July 2021).

91. Dental Endodontics Market (Product-Instruments (Endodontic Scalers \& Lasers, Motors, Apex Locators, and Machine Assisted Obturation Systems) and Consumables (Obturation, Shaping and Cleaning, and Access Cavity Preparation); End User: Dental Hospitals, Dental Clinics, and Dental Academic \& Research Institutes)—Global Industry Analysis, Size, Share, Growth, Trends, and Forecast 2017-2025. Available online: https: / / www.transparencymarketresearch.com/dental-endodontics-market.html (accessed on 23 July 2021).

92. Dobrzańska, J.; Dobrzański, L.B.; Gołombek, K.; Dobrzański, L.A.; Dobrzańska-Danikiewicz, A.D. Virtual approach to the comparative analysis of biomaterials used in endodontic treatment. Processes 2021, 9, 926. [CrossRef]

93. Cohen, S.; Hargreaves, K. Pathways of the Pulp, 9th ed.; Mosby: St. Louis, MO, USA, 2006.

94. Krasner, P.; Rankow, H.J.; Abrams, E.S. Endodontics. Colleagues for Excellence. Access Opening and Canal Location; American Association of Endodontists: Chicago, IL, USA, 2010.

95. Krasner, P.; Rankow, H.J. Anatomy of the pulp-chamber floor. J. Endod. 2004, 30, 5-16. [CrossRef]

96. Dobrzańska, J.; Dobrzański, L.B.; Dobrzański, L.A.; Gołombek, K.; Dobrzańska-Danikiewicz, A.D. Is Gutta-Percha Still the “Gold Standard" among Filling Materials in Endodontic Treatment? Processes 2021, 9, 1467. [CrossRef]

97. Dobrzańska, J.; Dobrzański, L.B.; Dobrzański, L.A.; Dobrzańska-Danikiewicz, A.D.; Gołombek, K. What Are the Chances of Resilon to Dominate the Market Filling Materials for Endodontics? Metals 2021, 11, 1744. [CrossRef]

98. Moreinis, S.A. Avoiding perforation during endodontic access. J. Am. Dent. Assoc. 1979, 98, 707-712. [CrossRef]

99. Sundqvist, G.; Figdor, D.; Persson, S.; Sjörgren, U. Microbiological analysis of teeth with failed endodontic treatment and the outcome of conservative re-treatment. Oral Surg. Oral Med. Oral Pathol. Oral Radiol. Endod. 1998, 85, 86-93. [CrossRef]

100. Siqueira, J.F.; Rocas, I.N.; Lopes, H.P.; de Uzeda, M. Coronal leakage of two root canal sealers containing calcium hydroxide after exposure to human saliva. J. Endod. 1999, 25, 14-16. [CrossRef]

101. Hirsch, J.M.; Ahlstrom, U.; Henrikson, P.A.; Peterson, L.E. Periapical surgery. Int. J. Oral Surg. 1979, 8, 173-185. [CrossRef] 
102. Carrotte, P. Endodontics: Part 1. The modern concept of root canal treatment. Br. Dent. J. 2004, 197, 181-183. [CrossRef] [PubMed]

103. Castellucci, A. Endodontics Vol. 1; Il Tridente Edizioni Odontolatriche: Bologna, Italy, 2005.

104. Dobrzański, L.A.; Dobrzański, L.B.; Dobrzańska, J.; Dobrzański, J.; Dobrzańska-Danikiewicz, A.D. Application of nitinol type alloys in teeth endodontic treatment. Processes 2021. prepared for printing.

105. Serafin, M.; De Biasi, M.; Franco, V.; Angerame, D. In vitro comparison of cyclic fatigue resistance of two rotary single-file endodontic systems: OneCurve versus OneShape. Odontology 2019, 107, 196-201. [CrossRef] [PubMed]

106. Serafin, M.; De Biasi, M.; Franco, V.; Generali, L.; Angerame, D. Influence of different motions on the cyclic fatigue resistance of Reciproc and Reciproc Blue endodontic instruments. J. Conserv. Dent. 2019, 22, 449-453. [CrossRef]

107. Barattolo, R.; Santarcangelo, F. Otturazione del sistema dei canali radicolari con guttaperca termoplasticizzata: Principi, materiali e tecniche. G. Italia. Endod. 2011, 25, 112-124. [CrossRef]

108. Nahmias, Y.; Mab, T.; Dovgan, J.S. The Thermo Hydraulic Condensation Technique. Oral Health 2001, 91, 11-18.

109. Carvalho-Sousa, B.; Almeida-Gomes, F.; Carvalho, P.R.; Maníglia-Ferreira, C.; Gurgel-Filho, E.D.; Albuquerque, D.S. Filling lateral canals: Evaluation of different filling techniques. Eur. J. Dent. 2010, 4, 251-256. [CrossRef]

110. Nahmias, Y.; Serota, K.S.; Watson, W.R., Jr. Predictable Endodontic Success: Part II—Microstructural Replication. Available online: http:/ / www.ecoweek.ca/issues/PrinterFriendly.asp?aid=1000156065\&RType=\&PC=\&issue=12012003 (accessed on 23 July 2021).

111. Dobrzański, L.A.; Dobrzański, L.B.; Dobrzańska-Danikiewicz, A.D. Overview of conventional technologies using the powders of metals, their alloys and ceramics in Industry 4.0 stage. J. Achiev. Mater. Manuf. Eng. 2020, 98, 56-85. [CrossRef]

112. Dobrzański, L.A.; Dobrzańska-Danikiewicz, A.D. Why Are Carbon-Based Materials Important in Civilization Progress and Especially in the Industry 4.0 Stage of the Industrial Revolution. Mater. Perform. Charact. 2019, 8, 337-370. [CrossRef]

113. Hermann, M.; Pentek, T.; Otto, B. Design Principles for Industrie 4.0 Scenarios: A Literature Review; Technische Universität Dortmund: Dortmund, Germany, 2015.

114. Dobrzański, L.A. Role of materials design in maintenance engineering in the context of industry 4.0 idea. J. Achiev. Mater. Manuf. Eng. 2019, 96, 12-49. [CrossRef]

115. Dobrzański, L.A.; Dobrzański, L.B.; Dobrzańska-Danikiewicz, A.D.; Kraszewska, M. Manufacturing powders of metals, their alloys and ceramics and the importance of conventional and additive technologies for products manufacturing in Industry 4.0 stage. Arch. Mater. Sci. Eng. 2020, 102, 13-41. [CrossRef]

116. Dobrzański, L.A.; Dobrzańska-Danikiewicz, A.D. Applications of Laser Processing of Materials in Surface Engineering in the Industry 4.0 Stage of the Industrial Revolution, Mater. Perform. Charact. 2019, 8, 1091-1129. [CrossRef]

117. Rüßmann, M.; Lorenz, M.; Gerbert, P.; Waldner, M.; Justus, J.; Engel, P.; Harnisch, M. Industry 4.0: The Future of Productivity and Growth in Manufacturing Industries; Boston Consulting Group: Boston, MA, USA, 2015.

118. Jose, R.; Ramakrishna, S. Materials 4.0: Materials Big Data Enabled Materials Discovery. Appl. Mat. Today. 2018, 10, 127-132. [CrossRef]

119. Kagermann, H.; Wahlster, W.; Helbig, J. Recommendations for Implementing the Strategic Initiative INDUSTRIE 4.0: Final Report of the Industrie 4.0 Working Group; Federal Ministry of Education and Research: Bonn, Germany, 2013.

120. Brettel, M.; Friederichsen, N.; Keller, M.; Rosenberg, M. How Virtualization, Decentralization, and Network-Building Change the Manufacturing Landscape: An Industry 4.0 Perspective. Int. J. Mech. Aerospac. Indust. Mechatron. Manuf. Eng. 2014, 8, 37-44.

121. Lee, J.; Kao, H.-A.; Yang, S. Service Innovation and Smart Analytics for Industry 4.0 and Big Data Environment. Proc. CIRP 2014, 16, 3-8. [CrossRef]

122. Posada, J.; Toro, C.; Barandiaran, I.; Oyarzun, D.; Stricker, D.; de Amicis, R.; Pinto, E.B.; Eisert, P.; Döllner, J.; Vallarino, I. Visual Computing as a Key Enabling Technology for Industrie 4.0 and Industrial Internet. IEEE Comp. Graph Appl. 2015, 35, 26-40. [CrossRef]

123. Tay, S.I.; Lee, T.C.; Hamid, N.A.A.; Ahmad, A.N.A. An Overview of Industry 4.0: Definition, Components, and Government Initiatives. J. Adv. Res. Dyn. Control Syst. 2018, 10, 1379-1387.

124. Kagermann, H. Chancen von Industrie 4.0 Nutzen. In Industrie 4.0 in Produktion, Automatisierung und Logistik; Springer Fachmedien Wiesbaden: Wiesbaden, Germany, 2014; pp. 603-614.

125. Sipsas, K.; Alexopoulos, K.; Xanthakis, V.; Chryssolouris, G. Collaborative Maintenance in Flow-Line Manufacturing Environments: An Industry 4.0 Approach. Proc. CIRP 2016, 55, 236-241. [CrossRef]

126. Bahrin, M.A.K.; Othman, M.F.; Azli, N.H.N.; Talib, M.F. Industry 4.0: A Review on Industrial Automation and Robotic. J. Teknol. 2016, 78, 137-143. [CrossRef]

127. Buer, S.-V.; Strandhagen, J.O.; Chan, F.T.S. The Link between Industry 4.0 and Lean Manufacturing: Mapping Current Research and Establishing a Research Agenda. Int. J. Prod. Res. 2018, 56, 2924-2940. [CrossRef]

128. Xu, X. Machine Tool 4.0 for the New Era of Manufacturing. Int. J. Adv. Manuf. Technol. 2017, 92, 1893-1900. [CrossRef]

129. Hozdic, E. Smart Factory for Industry 4.0: A Review. Int. J. Mod. Manuf. Technol. 2015, 7, $28-35$.

130. Stock, T.; Seliger, G. Opportunities of Sustainable Manufacturing in Industry 4.0. Proc. CIRP 2016, 40, 536-541. [CrossRef]

131. Almada-Lobo, F. The Industry 4.0 Revolution and the Future of Manufacturing Execution Systems (MES). J. Innov. Manag. 2015, 3, 16-21. [CrossRef]

132. Lee, J.; Bagheri, B.; Kao, H.-A. A Cyber-Physical Systems Architecture for Industry 4.0-Based Manufacturing Systems. Manuf. Lett. 2015, 3, 18-23. [CrossRef] 
133. Thoben, K.-D.; Wiesner, S.; Wuest, T. 'Industrie 4.0' and Smart Manufacturing-A Review of Research Issues and Application Examples. Int. J. Autom. Technol. 2017, 11, 4-16. [CrossRef]

134. Zhong, R.Y.; Xu, X.; Klotz, E.; Newman, S.T. Intelligent Manufacturing in the Context of Industry 4.0: A Review. Engineering 2017, 3, 616-630. [CrossRef]

135. Vaidya, S.; Ambad, P.; Bhosle, S. Industry 4.0-A Glimpse. Proc. Manuf. 2018, 20, 233-238. [CrossRef]

136. Wang, S.; Wan, J.; Zhang, D.; Li, D.; Zhang, C. Towards Smart Factory for Industry 4.0: A Self-Organized Multi-Agent System with Big Data Based Feedback and Coordination. Comput. Netw. 2016, 101, 158-168. [CrossRef]

137. Kumar, K.; Zindani, D.; Davim, J.P. Industry 4.0: Developments towards the Fourth Industrial Revolution; Springer Nature: Singapore, 2019.

138. Qin, J.; Liu, Y.; Grosvenor, R. A Categorical Framework of Manufacturing for Industry 4.0 and Beyond. Proc. CIRP 2016, 52, 173-178. [CrossRef]

139. Ardito, L.; Petruzzelli, A.M.; Panniello, U.; Garavelli, A.C. Towards Industry 4.0: Mapping Digital Technologies for Supply Chain Management-Marketing Integration. Bus. Proc. Manag. J. 2019, 25, 323-346. [CrossRef]

140. Schumacher, A.; Erol, S.; Sihn, W. A Maturity Model for Assessing Industry 4.0 Readiness and Maturity of Manufacturing Enterprises. Proc. CIRP 2016, 52, 161-166. [CrossRef]

141. Mosterman, P.J.; Zander, J. Industry 4.0 as a Cyber-Physical System Study. Softw. Syst. Modeling 2016, 15, 17-29. [CrossRef]

142. Pfeiffer, S. Robots, Industry 4.0 and Humans, or Why Assembly Work Is More than Routine Work. Societies 2016, 6, 16. [CrossRef]

143. Lu, Y. Industry 4.0: A Survey on Technologies, Applications and Open Research Issues. J. Ind. Inf. Integr. 2017, 6, 1-10. [CrossRef]

144. Łobaziewicz, M. Zarzadzanie Inteligentnym Przedsiębiorstwem w Dobie Przemystu 4.0; Towarzystwo Naukowe Organizacji i Kierownictwa: Torun, Poland, 2019.

145. Dobrzański, L.A.; Dobrzański, L.B. Dentistry 4.0 Concept in the Design and Manufacturing of Prosthetic Dental Restorations. Processes 2020, 8, 525. [CrossRef]

146. Dobrzański, L.A.; Dobrzański, L.B.; Achtelik-Franczak, A.; Dobrzańska, J. Application Solid Laser-Sintered or Machined Ti6Al4V Alloy in Manufacturing of Dental Implants and Dental Prosthetic Restorations According to Dentistry 4.0 Concept. Processes 2020, 8, 664. [CrossRef]

147. Dobrzański, L.B.; Achtelik-Franczak, A.; Dobrzańska, J.; Dobrzański, L.A. Comparison of the Structure and Properties of the Solid Co-Cr-W-Mo-Si Alloys Used for Dental Restorations CNC Machined or Selective Laser-Sintered. Mater. Perform. Charact. 2020, 9. [CrossRef]

148. Dobrzańska-Danikiewicz, A.D. Foresight of Material Surface Engineering as a Tool Building a Knowledge-Based Economy. Mater Sci. Forum 2012, 706-709, 2511-2516. [CrossRef]

149. Dobrzański, L.A.; Dobrzański, L.B.; Dobrzańska-Danikiewicz, A.D. Manufacturing technologies thick-layer coatings on various substrates and manufacturing gradient materials using powders of metals, their alloys and ceramics. J. Achiev. Mater. Manuf. Eng. 2020, 99, 14-41. [CrossRef]

150. Dobrzańska-Danikiewicz, A.D. Metodologia komputerowo zintegrowanego prognozowania rozwoju inżynierii powierzchni materiałów. In Open Access Library; Dobrzański, L.A., Ed.; International OCSCO World Press: Gliwice, Poland, 2012; Volume 1, pp. $1-289$.

151. Dobrzańska-Danikiewicz, A. The methodological fundaments of development state analysis of surface engineering technologies. J. Achiev. Mater. Manuf. Eng. 2010, 40, 203-210.

152. Dobrzańska-Danikiewicz, A.D.; Dobrzański, L.A.; Szindler, M.; Achtelik-Franczak, A.; Dobrzański, L.B. Obróbka powierzchni materiałów mikroporowatych wytworzonych metodą selektywnego spiekania laserowego w celu uefektywnienia proliferacji żywych komórek. In Metalowe Materiały Mikroporowate i Lite do Zastosowań Medycznych i Stomatologicznych; Open Access Library Volume VII, 1; Dobrzański, L.A., Dobrzańska-Danikiewicz, A.D., Eds.; International OCSCO World Press: Gliwice, Poland, 2017; pp. 289-375.

153. Dobrzańska-Danikiewicz, A.D.; Hajduczek, E.; Polok-Rubiniec, M.; Przybył, M.; Adamaszek, K. Evaluation of selected steel thermochemical treatment technologies using foresight methods. J. Achiev. Mater. Manuf. Eng. 2011, 46, 115-146.

154. Dobrzańska-Danikiewicz, A.D.; Tański, T.; Malara, S.; Domagała-Dubiel, J. Technology Foresight Results Concerning Laser Surface Treatment of Casting Magnesium Alloys. In New Features on Magnesium Alloys; Monteiro, W.A., Ed.; IntechOpen: Rijeka, Croatia, 2012; pp. 1-30. [CrossRef]

155. Dobrzańska-Danikiewicz, A.D. The development perspectives of Physical Vapour Deposition technologies. J. Achiev. Mater. Manuf. Eng. 2012, 54, 103-109.

156. Dobrzańska-Danikiewicz, A.D. Księga technologii krytycznych kształtowania struktury i własności powierzchni materiałów inżynierskich. In Open Access Library; Dobrzański, L.A., Ed.; International OCSCO World Press: Gliwice, Poland, 2013; Volume 8, pp. $1-823$.

157. Dobrzański, L.A.; Achtelik-Franczak, A. Struktura i własności tytanowych szkieletowych materiałów mikroporowatych wytworzonych metodą selektywnego spiekania laserowego do zastosowań w implantologii oraz medycynie regeneracyjnej. In Metalowe Materiały Mikroporowate i Lite do Zastosowań Medycznych i Stomatologicznych; Dobrzański, L.A., Dobrzańska-Danikiewicz, A.D., Eds.; International OCSCO World Press: Gliwice, Poland, 2017; Open Access Library Volume VII, pp. 186-244.

158. Dobrzańska-Danikiewicz, A.D. (Ed.) Materials surface engineering development trends. In Open Access Library; International OCSCO World Press: Gliwice, Poland, 2011; Volume 6, pp. 1-594. 
159. Dobrzański, L.A. Effect of heat and surface treatment on the structure and properties of the Mg-Al-Zn-Mn casting alloys. In Magnesium and Its Alloys; Dobrzański, L.A., Totten, G.E., Bamberger, M., Eds.; CRC Press: Boca Raton, FL, USA, 2019 ; pp. 91-202.

160. Dobrzańska-Danikiewicz, A.D.; Dobrzański, L.A.; Sękala, A. Results of Technology Foresight in the Surface Engineering Area. Appl. Mech. Mater. 2014, 657, 916-920. [CrossRef]

161. Dobrzański, L.A.; Dobrzańska-Danikiewicz, A.D. Foresight of the Surface Technology in Mnufacturing. In Handbook of Manufacturing Engineering and Technology; Nee, A.Y.C., Ed.; Springer-Verlag: London, UK, 2016; ISBN 1-4471-4671-1.

162. Dobrzańska-Danikiewicz, A.D.; Dobrzański, L.A.; Mazurkiewicz, J.; Tomiczek, B.; Reimann, Ł. E-transfer of materials surface engineering e-foresight results. Arch. Mater. Sci. Eng. 2011, 52, 87-100.

163. Dobrzański, L.A. (Ed.) 1st Workshop on Foresight of Surface Properties Formation Leading Technologies of Engineering Materials and Biomaterials; International OCSCO World Press: Gliwice, Poland, 2009; pp. 1-272.

164. Dobrzański, L.A.; Dobrzańska-Danikiewicz, A.D. (Eds.) 3rd Workshop on Foresight of Surface Properties Formation Leading Technologies of Engineering Materials and Biomaterials; Raport z realizacji zadania 2. "Analiza istniejacej sytuacji w zakresie rozwoju technologii oraz uwarunkowań społeczno-gospodarczych w odniesieniu do przedmioty foresightu pt. FORSURF-foresight wiodących technologii kształtowania własności powierzchni materiałów inżynierskich i biomedycznych"; International OCSCO World Press: Gliwice, Poland, 2010; pp. 1-184.

165. Dobrzański, L.A. (Ed.) 2nd Workshop on Foresight of Surface Properties Formation Leading Technologies of Engineering Materials and Biomaterials; International OCSCO World Press: Gliwice, Poland, 2009; pp. 1-324.

166. Henderson, B. The Product Portfolio. Available online: https://www.bcg.com/publications/1970/strategy-the-product-portfolio (accessed on 23 July 2021).

167. Dobrzański, L.B. Struktura i Własności Materiałów Inżynierskich na Uzupełnienia Protetyczne Układu Stomatognatycznego Wytwarzane Metodami Przyrostowymi i Ubytkowymi. Ph.D. Thesis, Akademia Górniczo-Hutnicza im. Stanisława Staszica w Krakowie, Kraków, Poland, 2017.

168. Dobrzański, L.A.; Hudecki, A.; Chladek, G.; Król, W.; Mertas, A. Biodegradable and antimicrobial polycaprolactone nanofibers with and without silver precipitates. Arch. Mater. Sci. Eng. 2015, 76, 5-26.

169. Dobrzański, L.A.; Nieradka-Buczek, B. Transparent conductive nanocomposite layers with polymer matrix and silver nanowires reinforcement. Arch. Mater. Sci. Eng. 2018, 93, 59-84. [CrossRef]

170. Dobrzański, L.A.; Prokopiuk vel Prokopowicz, M. The influence of reduced graphene oxide on the structure of the electrodes and the properties of dye-sensitized solar cells. Arch. Mater. Sci. Eng. 2016, 77, 12-30. [CrossRef]

171. Dobrzański, L.A.; Dobrzańska-Danikiewicz, A.D.; Czuba, Z.P.; Dobrzański, L.B.; Achtelik-Franczak, A.; Malara, P.; Szindler, M.; Kroll, L. Metallic skeletons as reinforcement of new composite materials applied in orthopaedics and dentistry. Arch. Mater. Sci. Eng. 2018, 92, 53-85. [CrossRef]

172. Dobrzańska, J. Analiza Szczelności Wypełnień Kanałów Korzeniowych. Ph.D. Thesis, Śląski Uniwersytet Medyczny w Katowicach, Zabrze, Poland, 2011.

173. Dobrzański, L.A.; Hudecki, A. Structure, geometrical characteristics and properties of biodegradable micro- and polycaprolactone nanofibers. Arch. Mater. Sci. Eng. 2014, 70, 5-13.

174. Dobrzańska-Danikiewicz, A.D.; Żmudzki, J. Development trends of mucous-borne dentures in the aspect of elastomers applications. Arch. Mater. Sci. Eng. 2012, 55, 5-13.

175. Dobrzański, L.A.; Dobrzańska-Danikiewicz, A.; Achtelik-Franczak, A. The structure and properties of aluminium alloys matrix composite materials with reinforcement made of titanium skeletons. Arch. Mater. Sci. Eng. 2016, 80, 16-30. [CrossRef]

176. Dobrzański, L.A.; Pawlyta, M.; Hudecki, A. Conceptual study on a new generation of the high-innovative advanced porous and composite nanostructural functional materials with nanofibers. J. Achiev. Mater. Manuf. Eng. 2011, 49, 550-565.

177. Andreasen, J.O.; Farik, B.; Munksgaard, E.C. Long-term calcium hydroxide as a root canal dressing may increase risk of root fracture. Dent. Traumatol. 2002, 18, 134-137. [CrossRef]

178. Tay, F.R.; Pashley, D.H. Monoblocks in root canals: A hypothetical or a tangible goal. J. Endod. 2007, 33, 391-398. [CrossRef]

179. Gillespie, W.T.; Loushine, R.J.; Weller, R.N.; Mazzoni, A.; Doyle, M.D.; Waller, J.L.; Pashley, D.H.; Tay, F.R. Improving the performance of EndoREZ root canal sealer with a dual-cured two-step self-etch adhesive. II. Apical and coronal seal. J. Endod. 2006, 32, 771-775. [CrossRef]

180. Koch, K.; Min, P.S.; Stewart, G.G. Comparison of apical leakage between Ketac Endo sealer and Grossman sealer. Oral Surg. Oral Med. Oral Pathol. 1994, 78, 784-787. [CrossRef]

181. Koch, K.; Brave, D. A new endodontic obturation technique. Dent. Today 2006, 25, 104-107.

182. Lee, K.W.; Williams, M.C.; Camps, J.J.; Pashley, D.H. Adhesion of endodontic sealers to dentin and gutta-percha. J. Endod. 2002, 28, 684-688. [CrossRef]

183. Nakashima, M.; Akamine, A. The application of tissue engineering to regeneration of pulp and dentin in endodontics. J. Endod. 2005, 31, 711-718. [CrossRef]

184. Feilzer, A.J.; de Gee, A.J.; Davidson, C.L. Setting stress in composite resin in relation to configuration of the restoration. J. Dent. Res. 1987, 66, 1636-1639. [CrossRef] [PubMed]

185. Li, L.L.; Wang, Z.Y.; Bai, Z.C.; Mao, Y.; Gao, B.; Xin, H.T.; Zhou, B.; Zhang, Y.; Liu, B. Three-dimensional finite element analysis of weakened roots restored with different cements in combination with titanium alloy posts. Chin. Med. J. 2006, 119, 305-311. [CrossRef] [PubMed] 
186. Lang, H.; Korkmaz, Y.; Schneider, K.; Raab, W.H. Impact of endodontic treatments on the rigidity of the root. J. Dent. Res. 2006, 85, 364-368. [CrossRef]

187. Williams, C.; Loushine, R.J.; Weller, R.N.; Pashley, D.H.; Tay, F.R. A comparison of cohesive strength and stiffness of Resilon and gutta-percha. J. Endod. 2006, 32, 553-555. [CrossRef] [PubMed]

188. Watanabe, T.; Miyazaki, M.; Inage, H.; Kurokawa, H. Determination of elastic modulus of the components at dentin-resin interface using the ultrasonic device. Dent. Mater. J. 2004, 23, 361-367. [CrossRef] [PubMed]

189. Wu, M.K.; van der Sluis, L.W.; Wesselink, P.R. Comparison of mandibular premolars and canines with respect to their resistance to vertical root fracture. J. Dent. 2004, 32, 265-268. [CrossRef] [PubMed]

190. Strange, K.A.; Tawil, P.Z.; Phillips, C.; Walia, H.D.; Fouad, A.F. Long-term Outcomes of Endodontic Treatment Performed with Resilon/Epiphany. J. Endod. 2019, 45, 507-512. [CrossRef]

191. Nair, S.S.; Patil, A.H.; Jain, A.K.; Mali, S.D.; Yadav, P.A.; Agrawal, S.S. Fundamental concept of monoblock in endodontics. Int. J. Adv. Res. 2021, 9, 539-546. [CrossRef]

192. Gatwood, R.S. Endodontic materials. Dent. Clin. N. Am. 2007, 15, 695-712. [CrossRef]

193. Shipper, G.; Ørstavik, D.; Teixeira, F.B.; Trope, M. An evaluation of microbial leakage in roots filled with a thermoplastic synthetic polymer-based root canal filling material (Resilon). J. Endod. 2004, 30, 342-347. [CrossRef]

194. Pawińska, M.; Kierklo, A.; Marczuk-Kolada, G. New technology in endodontics-The Resilon-Epiphany system for obturation of root canals. Adv. Med. Sci. 2006, 51 (Suppl. S1), 154-157.

195. Lotfi, M.; Ghasemi, N.; Rahimi, S.; Vosoughhosseini, S.; Saghiri, M.A.; Shahidi, A. Resilon: A comprehensive literature review. J. Dent. Res. Dent. Clin. Dent. Prospect. 2013, 7, 119-130. [CrossRef]

196. Pocket Dentistry. Gutta-Percha Substitute: Resilon. Available online: https://pocketdentistry.com/33-gutta-percha-substituteresilon/ (accessed on 23 July 2021).

197. Lipski, M.; Woźniak, K.; Buczkowska-Radlińska, J.; Łagocka, R.; Bochińska, J.; Nowicka, A. Resilon i Epiphany nowy materiał do wypełniania kanałów korzeniowych zębów: Badania wstępne w SEM. Mag. Stomatol. 2005, 9, 108-112.

198. Resilon ${ }^{\mathrm{TM}}$ Obturation Material—The New Standard of Care? Available online: https://www.endoexperience.com/filecabinet/ Clinical\%20Endodontics/Obturation/Resilon/Resilon.Fact.Sheet.pdf (accessed on 23 July 2021).

199. Mohammadi, Z.; Jafarzadeh, H.; Shalavi, S.; Bhandi, S.; Kinoshita, J. Resilon: Review of a New Material for Obturation of the Canal. J. Contemp. Dent. Pract. 2015, 16, 407-414. [CrossRef]

200. Barnett, F.; Trope, M. Resilon ${ }^{\mathrm{TM}}$ : A novel material to replace gutta-percha. Contemp. Endod. 2004, 1, 16-19. 